

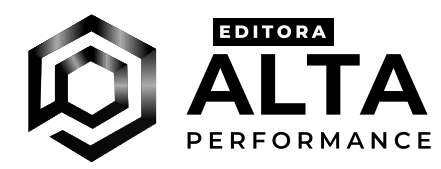

Larissa Rodrigues Ribeiro Pereira Diretora Administrativa

\section{Paulo Bento}

Diretor comercial

\section{CONSELHO EDITORIAL}

Prof. Me. Gil Barreto Ribeiro (PUC Goiás) - Presidente

\section{ACADÊMICO}

Prof. Me. Adriano Cielo Dotto (Una Catalão) Prof. Dr. Aguinaldo Pereira (IFRO)

Profa. Dra. Christiane de Holanda Camilo (UNITINS/UFG) Prof. Me. Dagoberto Rosa de Jesus (IFMT)

Profa Dra. Deise Nanci de Castro Mesquita (Cepae/UFG) Prof. Dr. José Maria Baldino (PUC Goiás)

Profa. Dra. Márcia Gorett Ribeiro Grossi (CEFET-MG)

Prof. Dr. Marcos Pereira dos Santos (FAQ)

Profa Me. Patrícia Fortes Lopes Donzele Cielo (Una Catalão) Profa. Dra. Rosane Castilho (UEG)

\section{CONSULTIVO}

Carlos Antônio Jordão Segundo

Frederico Nardi

Paulo Bento

Rebecca Oliveira 


\section{Suelene Vaz da Silva \\ Cleide Araújo Machado \\ Mirelle Amaral de São Bernardo}

Organizadoras

\section{PORTUGUÊS COMO LÍNGUA DE ACOLHIMENTO: EXPERIÊNCIAS NA AÇÃO DE EXTENSÃO 'MOVIMENTOS MIGRATÓRIOS EM V'}

$1^{\mathrm{a}}$ edição

Goiânia - Goiás

Editora Alta Performance

- 2021 - 


\section{Copyright ${ }^{\odot} 2021$ by Suelene Vaz da Silva, Cleide Araújo Machado, Mirelle Amaral de São Bernardo}

\section{Editora Alta Performance}

Rua 22, n 108, Quadra E9, Lote 57

Setor Oeste - CEP: 74.120-130 - Goiânia/Goiás

CNPJ: 21.538.101.0001-90

Site: http://editoraaltaperformance.com.br/

\section{Contatos:}

Larissa Pereira - (62) 98230-1212

Editoração: Franco Jr. Imagem da capa: Pixabay/ Parentrap

CIP - Brasil - Catalogação na Fonte

P853 Português como língua de acolhimento : experiências na ação de extensão 'movimentos migratórios em $V^{\prime}$ [ [livro eletrônico] / Organizadoras Suelene Vaz da Silva, Cleide Araújo Machado e Mirelle Amaral de São Bernardo. - 1. ed. - Goiânia : Editora Alta Performance, 2021. 142 p. ; Ebook.

Inclui referências bibliográficas

ISBN: 978-65-995656-5-6

1. Língua portuguesa - segunda língua - acolhimento. I. Silva, Suelene Vaz da (org.). II. Machado, Cleide Araújo. (org.). III. Bernardo, Mirelle Amaral de São (org.).

CDU 81'1

O conteúdo da obra e sua revisão são de total responsabilidade dos autores.

\section{DIREITOS RESERVADOS}

É proibida a reprodução total ou parcial da obra, de qualquer forma ou por qualquer meio, sem a autorização prévia e por escrito dos autores. A violação dos Direitos Autorais (Lei no 9.610/98) é crime estabelecido pelo artigo 184 do Código Penal. 


\section{SUMÁRIO}

APRESENTAÇÃO

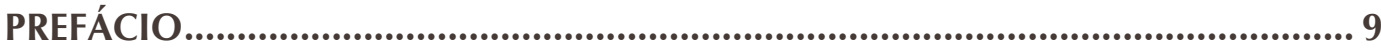

Parte I

CONTEXTUALIZAÇÃO DA AÇÃO NO INSTITUTO FEDERAL DE EDUCAÇÃO, CIÊNCIA E TECNOLOGIA DE GOIÁS, CÂMPUS GOIÂNIA

MOVIMENTOS MIGRATÓRIOS EM V(IRTUAL): O ENSINO DE PORTUGUÊS PARA FALANTES DE OUTRAS LÍNGUAS NO IFG, CÂMPUS GOIÂNIA

Suelene Vaz da Silva

Cleide Araújo Machado

Mirelle Amaral de São Bernardo

Parte II

EXPERIÊNCIAS COM A DOCÊNCIA DE PROFESSORES EM FORMAÇÃO COM ENSINO DE PORTUGUÊS COMO SEGUNDA LÍNGUA

ÓTÓ!' DIÁLOGOS NA PRÁTICA DE ENSINO DE PORTUGUÊS COMO LÍNGUA NÃO MATERNA PARA INDÍGENAS XAVANTE.

Amanda de Sousa Ywamoto

Alita Carvalho Miranda Paraguassú

DESAFIOS E NOVOS CAMINHOS DO ENSINO DE PORTUGUÊS COMO SEGUNDA LÍNGUA POR MEIO DE PLATAFORMAS DIGITAIS 32

Katiele Ribeiro Oliveira

Thaise Monteiro da Silva Melo

A IMPORTÂNCIA DAS TROCAS CULTURAIS NO PROCESSO DE ENSINO-APRENDIZAGEM DE PORTUGUÊS COMO SEGUNDA LÍNGUA: EXPERIÊNCIAS EM UMA TURMA DE PRÉ-PEC-G

Lívia Regina Borges Pereira

Mariana Alves de Oliveira

Thalía Marques de Andrade

Paula Graciano Pereira 
Parte III

EXPERIÊNCIAS COM A DOCÊNCIA DE PROFESSORES EM FORMAÇÃO COM ENSINO DE PORTUGUÊS COMO LÍNGUA DE ACOLHIMENTO

TECNOLOGIAS EM MOVIMENTO: REFLEXÕES SOBRE A PRÁTICA NO

ENSINO DE PORTUGUÊS COMO LÍNGUA DE ACOLHIMENTO MEDIADA

POR PLATAFORMAS DIGITAIS

62

Isaque Lima da Silva

Kamilla Christina Alves

Suelene Vaz da Silva

O ACOLHER E O SABER: EXPERIÊNCIAS COM O ENSINO DE PLAC

MEDIADO POR TECNOLOGIA DIGITAL PARA MIGRANTES HAITIANOS 78

Hamayana Silva Melo

Suelene Vaz da Silva

UMA LICENCIANDA ENSINANDO PORTUGUÊS PARA ESTRANGEIROS:

RELATO DE UMA EXPERIÊNCIA DE ENSINO DE PLAc A DISTÂNCIA 92

Milena de Oliveira Gomes

Liberato Santos da Silva

MEDIAÇÃO NO PLAc COMO ESTRATÉGIA DE ENSINO DE PORTUGUÊS

BRASILEIRO PARA HAITIANOS: UM INTERCÂMBIO CULTURAL 107

Clara Oliveira Campos

Ana Cristina de Moura dos Santos

Cleide Araújo Machado

TROCAS INTERCULTURAIS COM MIGRANTES VENEZUELANOS:

REFLEXÕES SOBRE PRÁTICAS DE ENSINO DE PORTUGUÊS COMO

LÍNGUA DE ACOLHIMENTO NA MODALIDADE DE ENSINO REMOTO

Angélica Maria Lourenço Moreira

Fabiana Thais Pereira Pedraza

Nayara Costa Araújo

Cleide Araújo Machado

ORGANIZADORAS/AUTORAS

135

AUTORES/AUTORAS 


\section{APRESENTAÇÃO}

V oar como os pássaros em busca de um local abundante em alimentos, com clima mais ameno ou ainda seguro o suficiente para a procriação é realizar uma jornada que se compara à de inúmeras pessoas que cruzam as fronteiras de seus países de origem na tentativa de encontrar, em outras terras, uma condição de vida melhor.

Para os pássaros, a migração é parte do próprio ciclo da vida, já para pessoas que se veem forçadas a tais mudanças, a migração pode trazer consigo dores e esperanças de dias melhores. É no prisma dessas esperanças que este livro foi construído. Partimos de uma ação, em 2017, intitulada 'Acolher, ensinar e aprender: português para migrantes em situação de vulnerabilidade social', para o Movimentos Migratórios em V: português para falantes de outras línguas, em 2020. Nessa etapa, todas as aulas foram executadas na modalidade de ensino remoto, via plataformas Google Meet, Google Classroom e aplicativo WhatsApp, em razão da pandemia de Covid-19.

São essas experiências, vivenciadas nessa modalidade virtual, que este e-book apresenta. Cada autor ou autora é membro da ação de ensino de português que atendeu, de julho a setembro de 2020, 88 pessoas, entre indígenas brasileiros da comunidade Xavante, haitianos e venezuelanos, na maioria residentes no estado de Goiás, e ainda alunos do Programa do Governo Federal Pec-G, de nacionalidades diversas. Tal como os pássaros que assumem a formação migratória em $\mathrm{V}$, cada um dos membros desta coletânea é um líder na formação em $V$ do ensino de língua portuguesa.

Esse voo migratório ainda abarca a formação pré-serviço e continuada para alunos e egressos do curso de Licenciatura em Letras: Língua Portuguesa, do

Instituto Federal de Goiás, câmpus Goiânia, os quais, enquanto voluntários no projeto, atuam como professores des aprendizes de português. Nessa perspectiva, desenvolvem suas habilidades docentes e, nesse momento de ensino remoto, por meio do tilintar de suas asas, vão também aprendendo a fazer uso de ambientes e ferramentas digitais para o ensino de língua portuguesa em contexto de acolhimento.

Espelhando, portanto, na formação em $\mathrm{V}$, este livro traz o trabalho colaborativo dos participantes da ação do projeto de extensão como mais um apoio ao destino migratório de pessoas que também desejam fazer parte do voo migratório de tantas pessoas que buscam no Brasil um território de acolhimento. 


\section{PREFÁCIO}

Ensino-aprendizagem de português como língua de acolhimento: o movi-

- mento docente no IFG, câmpus Goiânia é uma coletânea de artigos e relatos de estudantes e professores do curso de Letras do Instituto Federal de Goiás - câmpus Goiânia - sobre a experiência no processo de ensino-aprendizagem da língua portuguesa para indígenas e imigrantes advindos, principalmente, de uma conjuntura de migração de crise.

Os trabalhos que compõem a coletânea destacam o papel da língua e da linguagem como elementos fundamentais para que esses falantes de outras línguas tenham acesso a saberes que os auxiliem na compreensão dos novos contextos nos quais pretendem se inserir e que, por meio da língua, possam assumir suas vozes em tais novos contextos. Nesse sentido, os trabalhos presentes na obra evidenciam o engajamento e o compromisso de um grupo de professores, pesquisadores e estudantes que acredita no Português como Língua de Acolhimento (PLAc) como um caminho para a alteridade e para o respeito.

Nesse sentido, Ensino-aprendizagem de português como língua de acolhimento: o movimento docente no IFG, câmpus Goiânia apresenta-se também como uma obra sobre formação docente em um campo em crescimento, mas ainda carente de atenção e investimento, que é o PLAc. Sob orientação de seus professores, os estudantes envolvidos no projeto trabalharam de forma colaborativa, buscaram metodologias e tecnologias, desenvolveram planejamentos de curso, criaram materiais didáticos e os adaptaram para as plataformas digitais, experienciando, assim, a tão dinâmica prática da docência em um cenário marcado pela pluralidade.

O Instituto Federal de Goiás, ao assumir esse projeto que engloba ensino, pesquisa, extensão e internacionalização, demonstra compromisso institucional com a formação de seus alunos e com as atuais demandas sociais. Que este movimento docente continue e que esta seja

a primeira de muitas coletâneas. Parabéns aos organizadores e a todos os envolvidos nesse corajoso projeto.

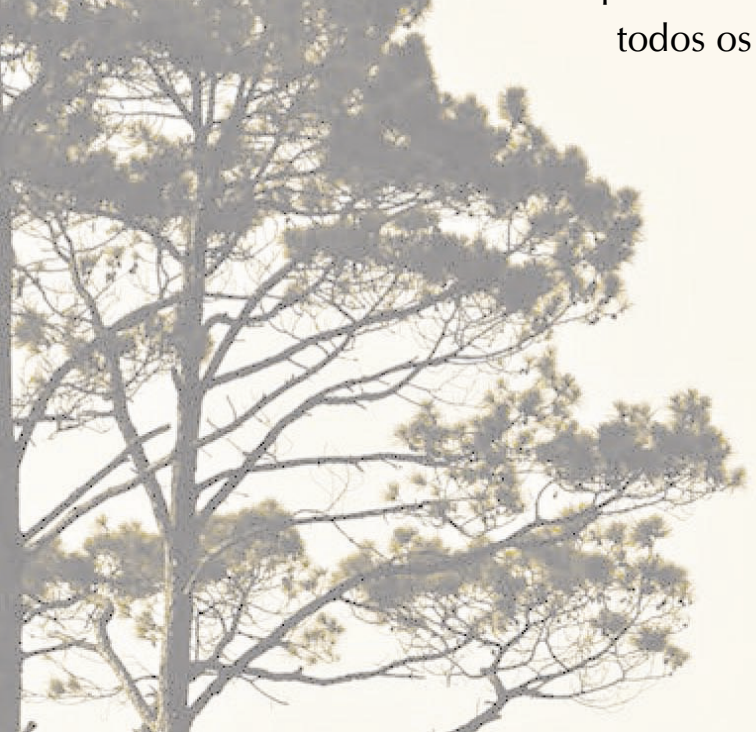

Natália Moreira Tosatti 


\section{MOVIMENTOS MIGRATÓRIOS EM V(IRTUAL): \\ O ENSINO DE PORTUGUÊS PARA FALANTES DE OUTRAS LÍNGUAS NO IFG, CÂMPUS GOIÂNIA}

Suelene Vaz da Silva

Cleide Araújo Machado Mirelle Amaral de São Bernardo
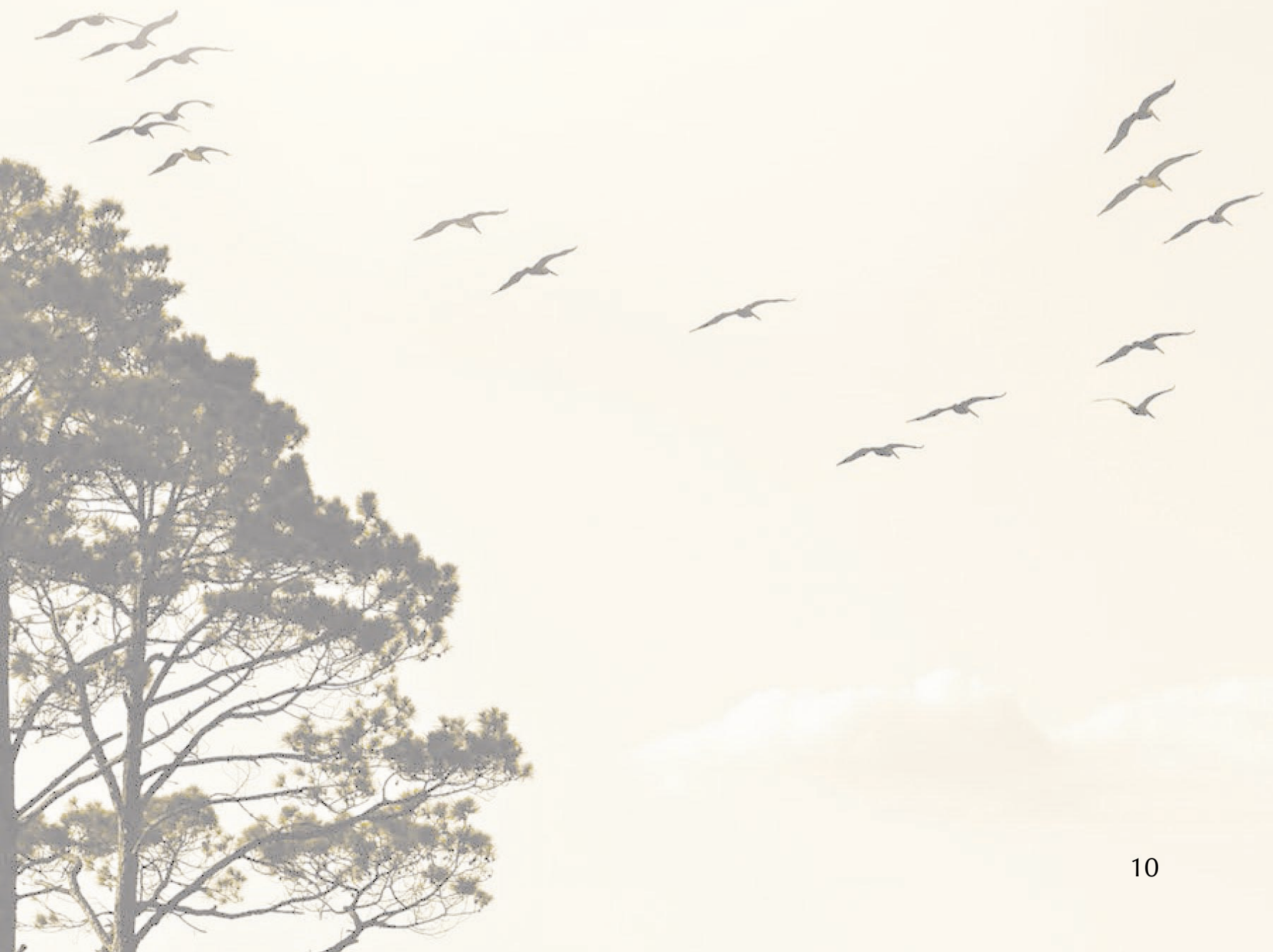
Resumo: Este capítulo inicial dos Anais do 'MoVirtual - I Seminário Movimentos Migratórios em V: português para falantes de outras línguas' apresenta o percurso do projeto de extensão, com o mesmo nome, desenvolvido de junho a dezembro de 2020, na modalidade remota por meio das plataformas digitais Google Meet, para as aulas síncronas, e do Google Classroom e WhatsApp, para as aulas assíncronas. A ação do projeto abarcou três segmentos de ensino de português: (1) português como língua de acolhimento para migrantes haitianos e venezuelanos, residentes em Goiânia ou em cidades circunvizinhas; (2) como segunda língua para alunos do Programa PEC-G, em fase preparatória para o exame Celpe-Bras, cuja certificação faz-se obrigatória para a realização do curso de graduação, objeto do Programa; e (3) como segunda língua para indígenas brasileiros da comunidade Xavante. A ação de ensino de português teve como regentes, majoritariamente, alunos de Licenciatura em Letras: Língua Portuguesa, do IFG, câmpus Goiânia, voluntários, os quais receberam a orientação de professores de línguas, que atuam como professores nesse curso de graduação. A equipe do projeto é composta, no geral, por servidores do IFG do câmpus Goiânia, Itumbiara e do coordenador de Relações Internacionais do IFG, além de um colaborador externo, membro da Pastoral do Migrante em Goiás.

Palavras-chave: MoVe. Ensino-aprendizagem de português. Formação docente. Acolher.

\section{Iniciando o voo virtual}

Ensino Remoto Emergencial, uma novidade para a maioria dos professo-
res do Instituto Federal de Educação, Ciência e Tecnologia de Goiás (IFG), câmpus Goiânia, tornou-se a modalidade educacional no ano de 2020 em praticamente todo o globo. Acostumados a pisar o chão firme da sala de aula, os professores do IFG tiveram as aulas presenciais transpostas para ambientes digitais desde agosto de 2020, em atendimento às medidas protetivas de saúde pública estabelecidas pelo Ministério da Saúde, as quais visavam minimizar a disseminação do coronavírus, causador da Covid-19.

Behar (2020, s.p) afirma que, devido ao caráter excepcional do contexto de pandemia de Covid-19, essa nova modalidade da educação deve ser chamada de Ensino Remoto Emergencial (ERE), e a define como "uma modalidade de ensino que pressupõe o distanciamento geográfico de professores e alunos e foi adotada de forma temporária nos diferentes níveis de ensino por instituições educacionais do mundo inteiro". A autora explica que:

[o] ensino é considerado remoto porque os professores e alunos estão impedidos por decreto de frequentarem instituições educacionais para evitar a disseminação do vírus. É emergencial porque do dia para noite o planejamento pedagógico para o ano letivo de 2020 teve que ser engavetado. (BEHAR, 2020, s.p).

Na mesma perspectiva, projetos com ações presenciais tiveram suas ações interrompidas ou igualmente remodeladas para os ambientes virtuais. Nessa linha, o pro- 
jeto de extensão 'Acolher, ensinar e aprender: português para imigrantes em situação de vulnerabilidade' (SILVA; SÃO BERNARDO, 2017), iniciado em 2017, com o propósito principal de oferecer acolhimento a imigrantes em situação de vulnerabilidade, residentes na cidade de Goiânia, Goiás, e regiões circunvizinhas, foi reapresentado às instâncias administrativas do IFG, na modalidade remota, sob o título 'Movimentos migratórios em V: português para falantes de outras línguas - MoVe' (SILVA, 2020).

Nessa proposição virtual, a ação do projeto foi ampliada para abarcar pessoas falantes de outras línguas, mas que não necessariamente eram imigrantes na perspectiva de vítimas da migração forçada. Para isso, a ação de ensino de Português como Língua de Acolhimento (PLAc) para migrantes haitianos e venezuelanos desdobrou-se em mais duas linhas: (2) português como segunda língua, para indígenas da comunidade Xavante, que haviam nos procurado em busca de aulas de português; e (3) português como segunda língua para alunos do Programa do Governo Federal Pec-G, na ação do projeto denominado de Pré Pec-G, uma vez que iriam realizar curso de português prévio ao curso superior com o objetivo de se prepararem para o exame de proficiência Celpe-Bras, e, assim, ingressarem no curso de graduação na instituição de ensino definida por meio das normas do programa em questão.

Criamos, via Google Forms, formulários de inscrição individualizados para os três grupos de alunos. Definimos por seguir a proposta do sistema presencial, em que alunos de Licenciatura em Letras: Língua Portuguesa do IFG, câmpus Goiânia, seriam os regentes, atuando em dupla ou em equipes, e os professores de Língua, do mesmo câmpus, seriam os orientadores desses alunos. Fizemos ainda uma enquete com os alunos matriculados para saber deles quais equipamentos e acesso à internet teriam para participar das aulas.

Figura 1. Formulários de inscrição

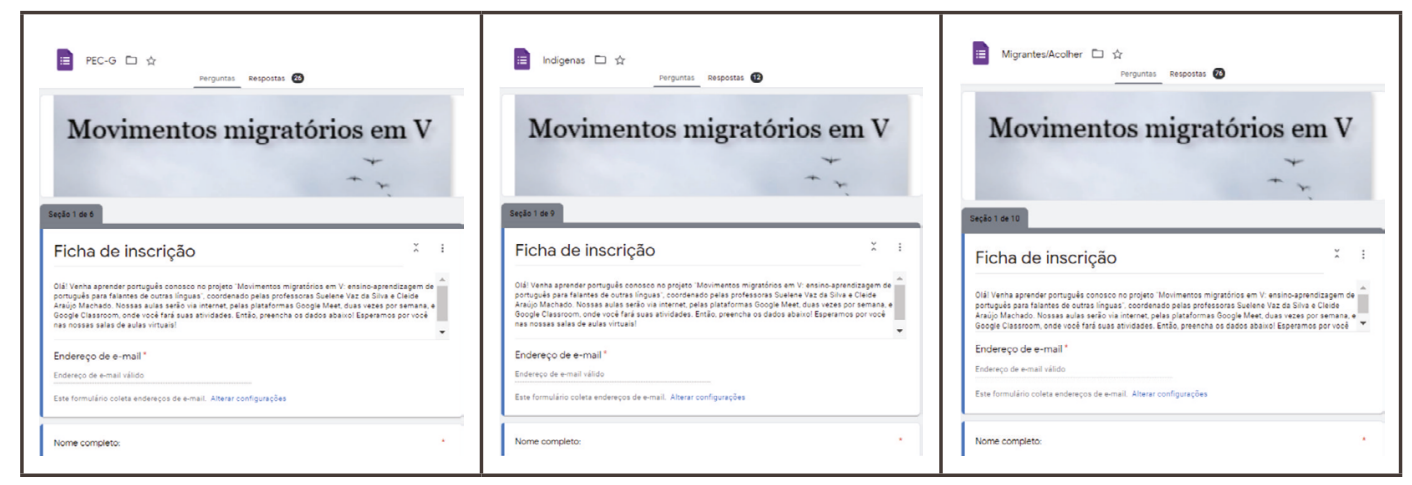

Fonte: Banco de dados do projeto MoVe.

Tivemos 124 inscrições de alunos haitianos e venezuelanos, cinco indígenas e 24 do Pré Pec-G, os distribuímos em dez turmas, que após a junção de duas tornaram-se nove turmas, a saber: cinco turmas para os alunos haitianos, subdivididas em ní- 
veis $\mathrm{A} 1, \mathrm{~A} 2, \mathrm{~A} 2+{ }^{1}, \mathrm{~B} 1$, Preparatório Vestibulares e Celpe-Bras; uma exclusiva para venezuelanos; três para o Pré Pec-G - que nos últimos meses de aulas foram agrupadas em duas turmas -, e uma para os indígenas. Era a primeira vez na ação do projeto que consideramos o fator língua próxima e língua distante para compor as turmas em relação aos venezuelanos e os haitianos. Tal definição mostrou-se muito profícua, pois as metodologias de ensino puderam ser aplicadas também considerando esse aspecto.

Tivemos 27 alunos de Licenciatura atuando como professores dos alunos de português, sob a orientação de seis professores de línguas: três com habilitação dupla em português/inglês, uma em português/espanhol, uma em português/literatura brasileira e outra, habilitação simples em português. O grupo de habilitação dupla assumiu, cada professor, duas turmas, o que ampliou o trabalho para os orientadores, pois a função de orientação envolvia mais de um encontro semanal com os orientandos para a organização das aulas síncronas e assíncronas. Esse trabalho envolvia discussão teórica sobre teorias relacionadas ao ensino de língua, com foco em PLAc e PL2, conforme o grupo; planejamento da aula, englobando a construção dos planos de aula, do material didático e das tarefas assíncronas, execução das aulas, pois os orientadores acompanharam todas as aulas síncronas, e, por fim, sessão-reflexiva acerca de todas as ações realizadas, especialmente da execução das aulas.

O contexto de ensino de PLAc é relativamente novo no Brasil, assim como o próprio conceito. Amado $(2011,2013)$ já defendia a importância da criação de políticas públicas para o ensino de português para imigrantes em situação de vulnerabilidade e defendia o ensino de português como língua de acolhimento, porém sem teorizar uma especificidade para esse conceito, colocando-o ainda subordinado ao conceito de português como língua estrangeira (PLE). O termo e a sigla PLAc foram cunhados a partir da pesquisa de São Bernardo (2016), em sua tese de doutorado. Assim, a autora entende que língua de acolhimento:

transcende a perspectiva linguística e cultural e refere-se também ao prisma emocional e subjetivo da língua e à relação conflituosa presente no contato inicial do imigrante com a sociedade de acolhimento, a julgar pela situação de vulnerabilidade que essas pessoas enfrentam ao chegarem a um país estrangeiro, com intenção de permanecer nesse lugar. (SÃO BERNARDO, 2016, p. 66).

Para apoiar os voluntários no trabalho com o ensino de PLAc, os orientadores ofereceram oficinas sobre as plataformas virtuais e algumas ferramentas que poderiam ser utilizadas para o ensino de português. Essas oficinas envolveram também algumas reflexões teóricas, principalmente na perspectiva da teoria sociocultural, da aprendizagem colaborativa, do ensino de línguas para fins específicos, na abordagem por tarefa e no ensino de línguas tomando outras línguas faladas pelos aprendizes como apoio

\footnotetext{
1 O símbolo 'mais' (+) foi utilizado para diferenciar duas turmas nomeadas de 'Turma A2'.
} 
à aprendizagem da língua portuguesa. Após a formação, iniciou-se a etapa de organização dos dias e horários para a realização das aulas para os migrantes e indígenas.

Definimos que as aulas síncronas teriam a duração de 90 minutos, ocorrendo duas vezes por semana, via plataforma Google Meet, e as assíncronas, conforme a necessidade de cada grupo, na plataforma do Google Classroom. Para tanto, foi criada uma sala de aula para cada turma. Os alunos receberam como ajuda de custo do IFG, câmpus Goiânia, via Pró-Reitorias de Extensão e de Ensino, a quantia de R $\$ 10,00$ por aula síncrona, como apoio para a aquisição de créditos para acesso à internet.

Figura 2. Salas do Google Classroom

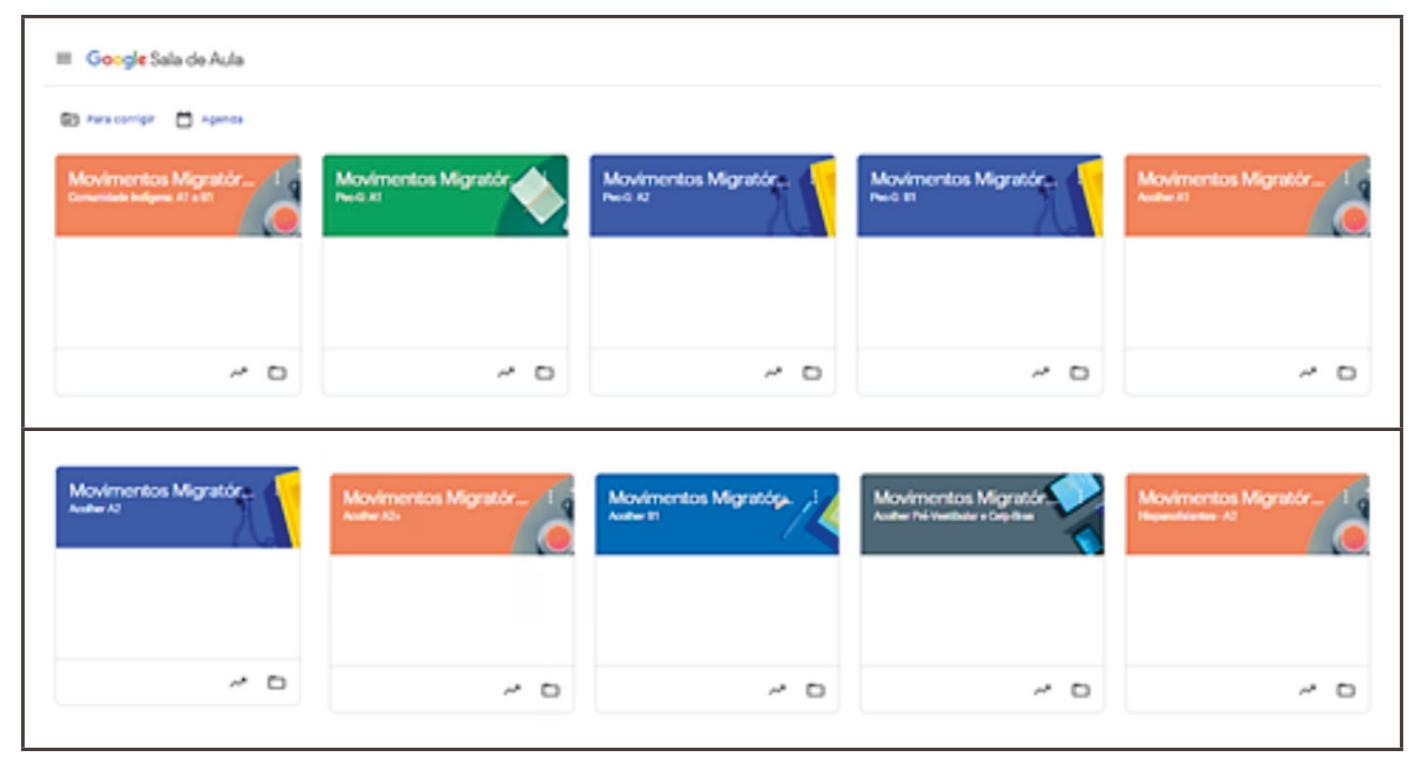

Fonte: Banco de dados do projeto MoVe.

As turmas compostas por alunos haitianos e venezuelanos tiveram as salas assíncronas do Google Classroom substituídas pelo aplicativo WhatsApp, pois, após o primeiro mês de aulas, os alunos não acessaram as tarefas postadas nessas salas. Alguns alegaram não terem conseguido realizar os procedimentos de acesso, apesar de todos os regentes terem feito tais procedimentos nas aulas síncronas e ainda terem criado tutoriais realizando o passo a passo de acesso à sala e às tarefas para os alunos, gravados via celulares em formato de imagem ou ainda de imagem com áudio. Os indígenas também não conseguiram acesso ao Classroom e nem ao Google Meet, tendo todas as aulas realizadas via WhatsApp. Os alunos do Pré Pec-G fizeram uso de ambos os ambientes sem apresentar maiores problemas de acesso.

Para nós, a dificuldade de acesso à plataforma das salas virtuais se deve principalmente ao fato de os alunos utilizarem para acompanhar as aulas de PL2 ou PLAc aparelhos celulares. Tais equipamentos exigem um pacote de dados mais amplo para conexão à internet, por conseguinte, a variedade de ambientes digitais acaba por oca- 
sionar um maior consumo desses dados, o que desmotiva o uso de outros ambientes virtuais. Considerando também que o aplicativo WhatsApp era de uso costumeiro de todos os alunos, a opção por essa ferramenta já familiar provavelmente trouxe mais conforto aos alunos para aulas virtuais. Seguindo a premissa de acolhimento, como postulam São Bernardo (2016), Grosso (2010), Ançã (2008), o ensino da língua precisa se aproximar da realidade do aluno, buscando trazer para o contexto de ensino a perspectiva de língua que agrega as necessidades dos aprendizes, proporcionando-lhes recursos para a aprendizagem, com o intuito de minimizar as barreiras de integração deles à comunidade de acolhimento.

Nesse sentido, o aplicativo tornou-se a sala de aula assíncrona, bem como o canal de comunicação entre regentes e alunos. A cada áudio ou texto escrito, os alunos e os professores faziam uso de suas habilidades de produção e de compreensão oral e escrita, mesmo quando o intuito não era abordar um determinado conteúdo. Assim, em contexto real, a língua foi cumprindo o seu papel de recurso integrador do aprendiz, migrante ou indígena, à comunidade falante de português, sem desconsiderar que eles são falantes de outras línguas, pois na comunicação, muitas vezes, outras línguas fizeram parte do repertório comunicativo. Essa perspectiva busca considerar que todas as línguas que os aprendizes já conhecem podem ser recursos importantes para a aprendizagem de uma outra língua, como apontam Cardoso, Coutinho e Oliveira (2018). Assim, o crioulo, língua falada pelos haitianos, o espanhol, falada pelos venezuelanos, ou as inúmeras línguas que os alunos do Pré PEC-G trazem para a sala de aula virtual, são bem-vindas como línguas de ancoragem para a aprendizagem do português.

Figura 3. Tela WhatsApp

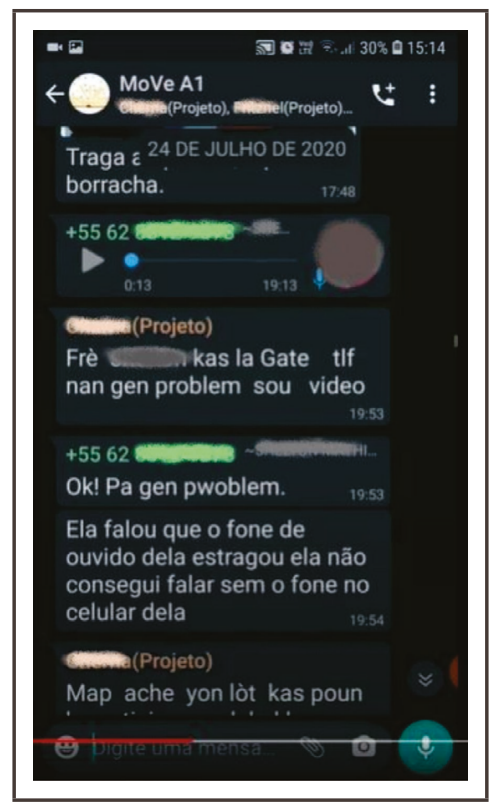

Fonte: Banco de dados do projeto MoVe. 
Em relação à organização do conteúdo didático, seguimos como base o livro Pode entrar: Português do Brasil para refugiadas e refugiados (Figura 3), produzido em parceria pelo Curso Popular Mafalda, o Alto Comissariado das Nações Unidas para Refugiados (Acnur) e a Cáritas Arquidiocesana de São Paulo (CASP) e disponibilizado para livre reprodução no site da Acnur ${ }^{2}$. Esse material é composto por unidades, organizadas por temáticas e por estruturas morfossintáticas da língua portuguesa. Os alunos receberam, em suas casas, uma cópia impressa do livro para acompanharem os conteúdos que estavam sendo trabalhados nas aulas e, caso fosse solicitado pelos professores, ou caso desejassem, poderiam realizar as tarefas apresentadas em cada unidade do livro.

Figura 4. Capa e sumário do Pode Entrar

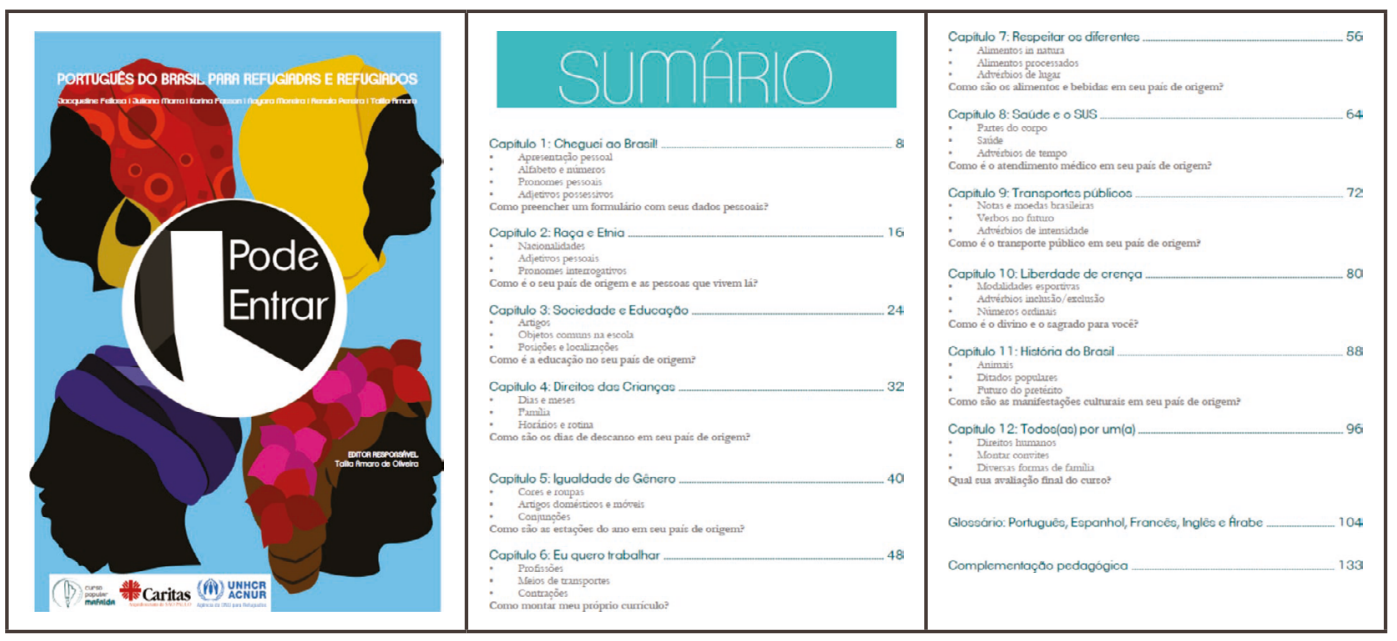

Fonte: Banco de dados do projeto MoVe.

Todos os seis orientadores e os professores regentes seguiram o livro como subsídio para a sequenciação das temáticas das aulas e como aspecto norteador para a construção das tarefas. Assim, algumas das aulas aproximam-se mais do conteúdo do livro do que outras. Contudo, ressaltamos que, para a modalidade de ensino remoto, a presença de um material didático norteador para as aulas facilitou o planejamento, uma vez que os regentes tinham uma referência para idealizar a aula e realizar a estruturação do material didático.

Todas as aulas foram armazenadas em pastas, criadas pelos orientadores, no Google Drive. Esse fato também contribuiu para o trabalho colaborativo de planejamento, escrita do plano de aula e elaboração de material didático, pois toda a equipe de uma turma podia trabalhar virtualmente, em momentos síncronos, ou assíncronos por meio dos aplicativos on-line da suíte Google, como o Google Docs, Forms e Apresentações.

2 Disponível em: https://www.acnur.org/portugues/2015/12/02/cartilha-ensina-portugues-a-refugiados-sob-a-perspectiva-dos-direitos-humanos/\# Acesso em:? 
Figura 5. Aulas armazenadas no Google Drive - Acolher A2 +

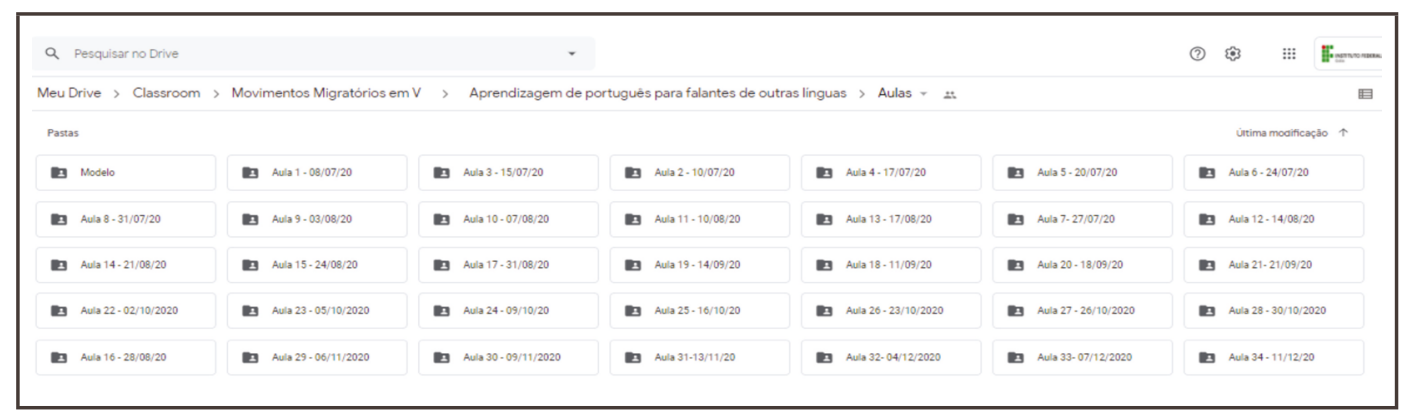

Fonte: Banco de dados do projeto MoVe.

Figura 6. Aula 26 - Acolher A2+

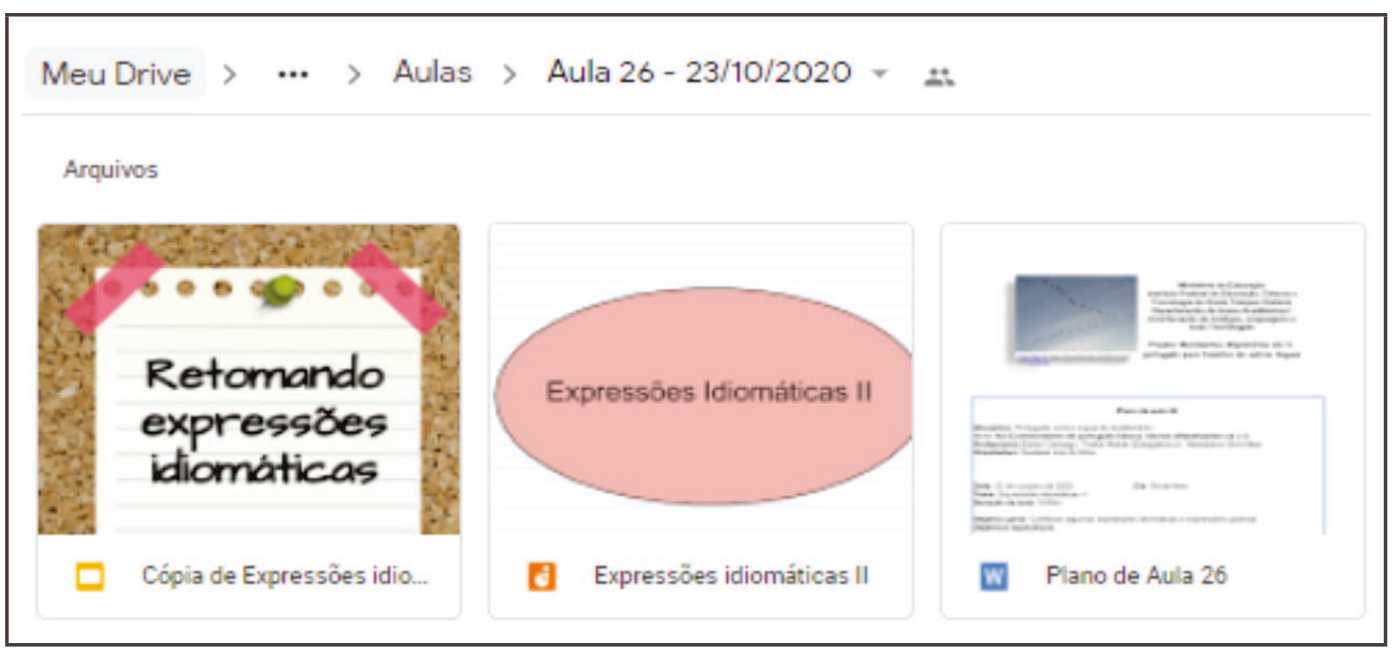

Fonte: Banco de dados do projeto MoVe.

As aulas iniciaram-se na primeira semana de junho com 88 alunos, distribuídos nas dez turmas da seguinte forma: 24 alunos do Pré PEC-G, cinco da comunidade Xavante, sete alunos venezuelanos e 52 haitianos. No final de dezembro, fechamos o semestre letivo virtual com 67 alunos, pois as aulas para os Xavantes estavam previstas para ocorrerem somente em julho e agosto. Das outras turmas, houve a desistência de 16 alunos, sendo a maioria haitianos. A razão principal da desistência, segundo relato de alguns dos alunos, foi o cansaço pela jornada de trabalho e a incompatibilidade do horário, também em razão de trabalho no período noturno.

Assim, apesar da perda, consideramos que a ação do projeto teve o seu valor por conseguir manter as aulas de PL2 e PLAc mesmo em contextos tão adversos para pessoas com restrição no acesso a bens de consumo relativos a tecnologias digitais. Para ilustrar as aulas, apresentamos um recorte de um plano de aula da turma AcoIher $\mathrm{A} 2$ + e do material didático utilizado na aula síncrona para a temática 'Saúde e especialidades médicas'. 
Figura 7. Aula 29 - Acolher A2+

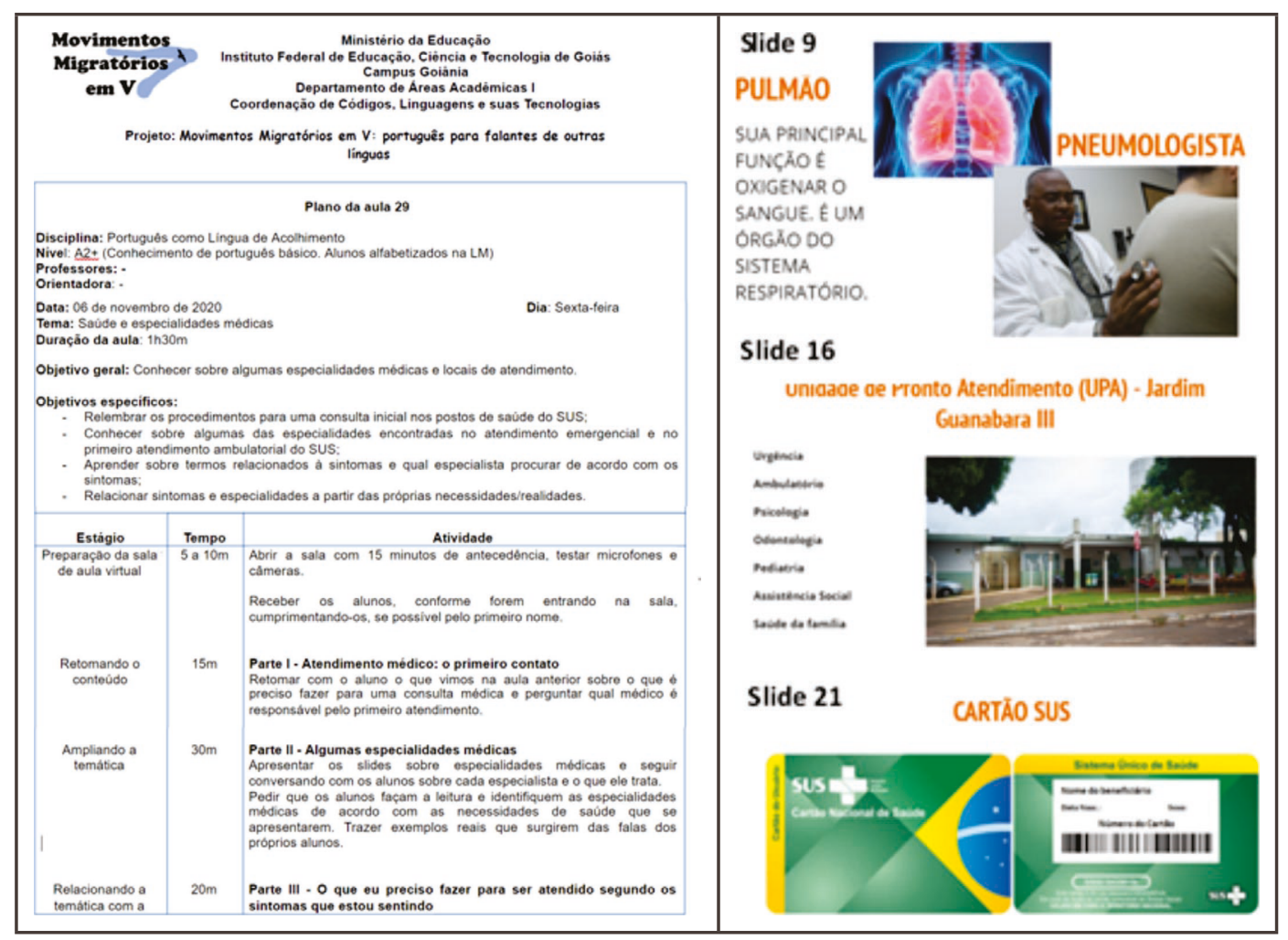

Fonte: Banco de dados do projeto MoVe.

Cada orientador definiu as metodologias e abordagens para as aulas das turmas sob sua supervisão, seguindo, como meta, a perspectiva de ensino voltada para o acolhimento, mesmo quando a visão de língua seguia a premissa de PL2 e não PLAc. Assim, os princípios defendidos por estudiosos da área de ensino de português para migrantes em situação de vulnerabilidade social, como Ançã (2018), Grosso (2010) e São Bernardo (2016), foram considerados da idealização à execução das aulas.

Nesse sentido, a língua é ensinada com o intuito de aproximar-se das necessidades de uso dos alunos, pensando sempre em quais contextos eles precisam dela, para realizar quais ações, tendo como interlocutores brasileiros. Não é um ensino instrumentalizado, mas que parte da percepção do contexto do aluno para expandir o trabalho com a língua, abarcando as estruturas linguísticas de acordo com o contexto de uso, sem fragmentar a relação entre falante, língua e cultura.

Nessa perspectiva, os alunos são o ponto de partida para o ensino e as culturas presentes são constituintes deste ensino. A língua, como acolhimento, busca dar vozes aos alunos, entender a situação de vulnerabilidade no novo contexto e abordar aspectos que possam minimizar essa condição de sujeito vulnerável. Há ainda a intenção de manter aberto o diálogo para questões afetivas e que englobam outros aspectos da vida do aluno, como acesso à saúde, ao trabalho, à educação. Assim, nas 
aulas, temas que problematizam e apontam meios para alcançar direitos garantidos a migrantes, no caso do MoVe, também aos indígenas brasileiros, são trazidos como conteúdo das aulas.

Para turmas mais iniciantes, o trabalho com a língua ainda se restringe muito à aprendizagem de vocabulários e da estrutura morfossintática da língua, contudo a partir das necessidades dos alunos. Nas turmas de nível mais avançado, as problematizações já são mais frequentes, considerando que os alunos conseguem se expressar oralmente e por escrito com mais segurança. Nas turmas que estudam a língua com a perspectiva de realizar exames para ensino superior, o foco já muda para atender aos conteúdos que são requisitados nos exames como Enem e de vestibulares da região goiana. Entretanto, ressaltamos que não são aulas para instrumentalizar o aluno, ao contrário, para contribuir com o desenvolvimento da criticidade perante a sociedade de acolhimento e a própria sociedade de origem, em uma perspectiva mais global quanto possível.

Nesse sentido, conteúdos literários são enfatizados na perspectiva de um trabaIho com arte e literatura, trazendo para o alunos artefatos culturais que possam subsidiar a compreensão de temáticas sociais, como em relação a gênero, preconceitos, discriminação, etc., presentes nas mais diferentes formas das esferas das sociedades. Os textos literários, como instrumentos linguístico-culturais, podem promover debates e discussões que permitam aos estudantes compreender a cultura do outro e a sua própria, tornando as aulas de PLAc um momento de 'humanização' dos sujeitos participantes. São Bernardo (2016, p. 48) defende:
A utilização de instrumentos os quais possibilitem que as/os aprendentes sejam ouvidos, que descentralizem o poder no ambiente de sala de aula, que propor- cionem aos aprendentes momentos em que utilizem a língua-alvo como ferra- menta para se fazer percebido, para contar a sua história, possa contribuir para essa humanização sugerida por Freire.

Além das aulas na modalidade virtual, O MoVe possibilitou-nos a realização de um seminário com a participação de pessoas de outros estados, que atuam com PLAc e com PL2, sem os gastos que envolvem o deslocamento, como os financeiros e gerência do tempo. O evento recebeu o nome de 'I Seminário Movimentos Migratórios em V: português para falantes de outras línguas (I MoVirtual)' e teve como tema 'Contextos virtuais de formação em movimento - a voz de estudiosos e as experiências de licenciandos regentes como professores de português para falantes de outras línguas'.

O seminário ocorreu de 19 a 26 de setembro de 2020, na plataforma Google Meet, e foi divulgado nas mídias da instituição e nas criadas para o próprio seminário: o Instagram (@movirtual2020) e um blog (https://seminariomovirtual.blogspot.com/). O blog ainda hospedou, além da programação e de divulgações diárias de notícias do evento, o 'Caderno de resumos', fato relevante por propiciar aos alunos de Letras pu- 
blicarem virtualmente os resumos de seus trabalhos. O seminário ainda possibilitou aos regentes apresentarem, em forma de comunicação oral, os trabalhos que estavam desenvolvendo com os alunos de português, bem como as experiências que consideraram exitosas, sejam no uso de uma ferramenta tecnológica específica, seja na abordagem de ensino ou outro aspecto ocorrido durante as aulas.

Durante o seminário, houve momentos para debates sobre os pontos positivos e as dificuldades que os regentes pudessem estar enfrentando com as aulas e ainda para o compartilhamento de ideias e práticas em relação ao material didático e modo de aplicação destes em ambiente virtual. Cinco palestras: (1) 'Percursos e desafios na formação do professor de Português como língua de acolhimento', com a professora Ms. Natália Moreira Tosatti, Cefet-MG; (2) 'Aprendendo a acolher: ensino de língua para pessoas em vulnerabilidade', pela Dra. Mirelle Amaral de São Bernardo, do IF Goiano; (3) 'Professora, não vai ter prova? - Reflexões sobre avaliação no ensi-

no de Português como Língua de Acolhimento', pela professora Ms. Ingrid Sinimbu Cruz, da UNB; (4) 'Conversas interculturais com migrantes haitianos e venezuelanos', por alunos migrantes haitianos e venezuelanos das turmas Hispanofalantes A2 e Acolher Pré-Vestibular e Celpe-Bras; e (5) 'Conhecendo o Haiti: País, Povo, Cultura', pelos alunos haitianos das turmas A2 e B1. Uma Mesa-redonda: 'Movimentos migratórios, língua e interculturalidade', com o professor Ms. Thiago Damasceno Pinto Milhomem, do IFG, e Brisa Xavier Pontes, da AFS; e ainda um debate acerca do filme 'O Labirinto do Fauno', com a professora Dra. Sara Guiliana Gonzales Belaonia, FL/UFG.

Desse evento resultou, além das publicações do resumo, da criação do Blog e do Instagram, estes sete artigos, com a escrita mais em caráter de relatos, escritos pelos regentes em colaboração com seus orientadores. Essa publicação inicia, muitos dos regentes, na escrita de artigo com foco em publicação, outro desdobramento da ação do projeto, motivar os alunos de Licenciatura à pesquisa. Nosso evento foi acompanhado por participantes de algumas regiões do Brasil e de diversas cidades do estado de Goiás, embora o nosso foco fosse propiciar aos regentes um espaço acadêmico para um trabalho científico, o evento teve um alcance muito maior que o esperado pela nossa comissão organizadora.

\section{Considerações finais}

A modalidade virtual de ensino de português, bem como ocorria no presencial, trouxe para a equipe a alegria de fazer parte de uma ação que proporciona compartilhar um pouco do nosso saber com pessoas em situação de vulnerabilidade social, entre elas, o desconhecimento da língua majoritária falada pela comunidade de acoIhimento. Quando idealizamos o projeto, as aulas no IFG ainda não haviam sido iniciadas na modalidade de Ensino Remoto Emergencial, mas, em função de dois proje- 
tos de ensino, 'As imagens nos afetam: interação através de tirinhas, HQs, charges e cartuns' e 'Overseas talks: chatting in English', percebemos que as tecnologias digitais poderiam também ser um meio para as aulas de português. Esse fato mostra que, quando estamos diante de situações novas, a experiência prática é um elemento fortalecedor para a motivação e enfrentamento de novos desafios. Somada a estes, a disposição de colegas de trabalho para a realização de um projeto, na grandiosidade do MoVe, minimiza as barreiras que precisam ser transpostas da idealização do projeto à sua finalização.

Para os licenciandos em Letras, a participação no MoVe deu-lhes a oportunidade de trabalhar em ambientes virtuais, sob a orientação de um professor experiente com ensino de línguas, e junto com esse professor aprender ou aprimorar o conhecimento acerca de diversas ferramentas, aplicando-as ao ensino de português. O Google Meet e o Google Classroom eram ambientes pioneiros, para a maioria dos professores, como salas de aulas virtuais. O uso do WhatsApp como ambiente oficial para aulas também era uma novidade para quase todos os participantes. Recursos digitais advindos do Google Docs, Google Forms, Google Apresentações, Jamborad, EducaPlay, WordWall, Genially, Canva, Kahoot, Quizur, Hot Potatoes, Rachacuca, The all e The all dice foram essenciais para que as aulas assumissem um caráter mais dinâmico.

Para os licenciandos, a aprendizagem sobre essas ferramentas e o uso real delas nas aulas contribuíram para a formação deles enquanto futuros professores de português, seja para brasileiros ou pessoas de outras nacionalidades, falantes de outras línguas. Esses licenciandos certamente estarão mais bem preparados para a era da tecnologia digital aliada à educação. Eles vivenciaram o que é exclusão digital e entenderam que essa forma de exclusão está em um âmbito muito mais complexo que o escolar. Eles também vivenciaram como driblar a exclusão, incluindo o aluno em ambientes virtuais a partir do equipamento tecnológico que o aluno traz e do acesso que ele possui à internet. Por outro lado, eles também possuem mais conhecimento para defenderem a necessidade da inclusão do letramento digital para todos.

O MoVe foi um espaço para ensinar, acolher e, principalmente, aprender. Aprendemos como compartilhar conhecimento e, mesmo na adversidade da pandemia, receber a visita de povos de nacionalidades diversas em nossas casas, nos nossos trabalhos, fez-nos pessoas melhores.

\section{Referências}

AMADO, R. S. O ensino de português como língua de acolhimento para refugiados. Revista da SIPLE, Brasília, ano 4, n. 2, out. 2013. Disponível em: https://www.researchgate.net/publication/272394920_O_ensino_de_portugues_como_lingua_de_acoIhimento_para_refugiados. Acesso em: 14 mai. 2020. 
AMADO, R. S. Português como Segunda Língua para comunidades de trabalhadores transplantados. Revista da Sociedade Internacional Português Língua Estrangeira (SIPLE), v. 2, 2011.

BEHAR, P. A. O Ensino Remoto Emergencial e a Educação a Distância. Rio Grande do Sul: UFRGS, 2020. Disponível em: https://www.ufrgs.br/coronavirus/base/artigo-o-ensino-remoto-emergencial-e-a-educacao-a- -distancia/. Acesso em: 27 maio 2020.

CARDOSO, J. da S.; COUTINHO, J.; OLIVEIRA, V. S. C. de. Reflexão sobre diferentes concepções de educação bilíngue. Linguagem: Estudos e Pesquisas, 2018. https://doi. org/10.5216/lep.v22i1.54459. Disponível em: https://www.revistas.ufg.br/lep/article/ view/54459/26047. Acesso em: 3 nov. 2020.

GROSSO. M. J. Língua de acolhimento, língua de integração. Horizontes de Linguística Aplicada, Belo Horizonte, v. 9, n. 2, p. 61-77, 2010. Disponível em: https:// www.academia.edu/6956350/L\%C3\%ADngua_de_acolhimento_l\%C3\%ADngua_ de_integra $\%$ C $3 \%$ A7\%C3\%A3o. Acesso em: 5 nov. 2020.

SÃO BERNARDO, M. A. de. Português como língua de acolhimento: um estudo com imigrantes e refugiados no Brasil. 206 f. 2016. Tese (Doutorado) - Programa de Pós-graduação em Linguística, Universidade Federal de São Carlos. 2016.

SILVA, S. V. da. Movimentos Migratórios em V: ensino de português para falantes de outras línguas. IFG - Projeto de Ensino-extensão vinculado ao projeto IFG - Saberes Inter/transdisciplinares, cadastrado no câmpus Goiânia, via SUAP, processo No 23373.001757/2020-30. IFG/câmpus Goiânia, de 2020.

SILVA, S. V. da; SÃO BERNARDO, M. A. de. Ensino de português para imigrantes em situação de vulnerabilidade: uma ação humanitária. IFG - Projeto de Extensão cadastrado na PROEX/IFG, julho de 2017. 
Resumo: Este texto tem como objetivo relatar as experiências linguísticas e culturais vivenciadas durante as Aulas de Português como Língua Não Materna para indígenas da etnia Xavante, localizados na Aldeia São Marcos, no estado de Mato Grosso. As atividades desenvolvidas fazem parte do projeto Movimentos Migratórios em $\mathrm{V}$, construído por professores e alunos do Instituto Federal de Goiás e integrantes da comunidade externa. As aulas síncronas e assíncronas ocorreram durante o Sistema de Ensino Emergencial instaurado devido à pandemia da Covid-19 e se basearam fundamentalmente nos estudos do texto e do discurso, em uma perspectiva dialógica intercultural.

Palavras-chave: Interculturalidade. Dialogismo. Língua Não Materna. Indígenas.

\section{O contexto de nossa interação}

Entre o final de 2019 e início de 2020, um grupo de indígenas, que conosco

Econvivia em atividades comunitárias externas à esfera escolar, nos procurou no Instituto Federal de Goiás, pois queriam "fazer curso". Durante uma visita guiada ao espaço de nossa instituição de ensino, os indígenas da etnia Xavante conversavam em sua língua materna entre si e em língua portuguesa conosco, ressaltando a importância de estudarem, de cursarem o ensino superior e retornarem para a aldeia São Marcos, em Mato Grosso, como professores. Segundo eles, vários professores indígenas da aldeia estão se aposentando e a escola indígena está em condições precárias. Ao lerem o guia de cursos do IFG alguns sinalizaram já saber o que queriam estudar: Engenharia, Letras-Português, Química.

No início de 2020, com a implantação do Sistema de Ensino Emergencial no IFG, devido à pandemia da Covid-19, convidamos os indígenas a participarem de um curso de extensão, em que seriam propostas práticas de leitura, escrita, fala e escuta em língua portuguesa. Nesse período, os indígenas já não estavam mais em Goiânia, na região leste da cidade, onde alugam residência, mas haviam retornado para a aldeia em Barra do Garças, a fim de se protegerem do vírus e receberem orientações e apoio adequados da Funai.

Abrimos um grupo no aplicativo WhatsApp para iniciarmos as nossas aulas de modo virtual. A nossa classe era composta por seis homens, na faixa etária de 17 a 32 anos, que já haviam adquirido o português como segunda língua e o usavam em situações comunicativas fora da aldeia, para estudar e trabalhar na cidade.

A língua materna de nosso grupo de alunos é a Xavante, pertencente ao tronco linguístico Macro-Jê, da família linguística Jê, mas desde a infância eles mantêm contato com a língua portuguesa na escola e nos arredores da aldeia. Os próprios nomes dos alunos são compostos por um nome em português e por um nome em Xavante. Como já sabiam falar, ouvir, ler e escrever em português, o objetivo das aulas era então aprofundar a consciência linguística dos indígenas relativa ao funcionamento da 
língua portuguesa em situações mais formais de uso, como vestibular, entrevista de emprego e leitura de sites e jornais.

A média de alunos que assistiam a nossas aulas síncronas por meio do aplicativo Google Meet era de cinco por aula e alguns saíam da sala com certa frequência por problemas de conexão. Nem todos tinham internet banda larga em casa ou dados móveis suficientes no celular, por isso, por vezes se deslocavam para a escola indígena, que permitia o uso da internet.

Nossas aulas eram dinâmicas, com interação tanto oral como escrita. A partir da leitura de textos que abordavam temáticas do interesse deles, como a preservação do meio ambiente, pedíamos para que falassem as sentenças e as escrevessem no chat do aplicativo Meet, assim tínhamos uma visão linguística tanto dos aspectos orais quanto dos aspectos escritos. Trabalhamos a formação de sentenças, o uso de pronomes, o uso do plural, a interpretação de textos jornalísticos, a leitura entoada de poemas e a compreensão de músicas.

O entendimento deles sobre vocábulos em português era muito bom, mas a funcionalidade de algumas palavras ainda não era compreendida, como no enunciado Moro na aldeia com meu pai e minha mãe, escrita por eles como Moro na Aldeia meu pai e minha mãe. Isso por que, segundo os nossos alunos indígenas, a língua Xavante não usa certos recursos gramaticais do português, como a preposição.

\section{Contribuições dos estudos do texto e do discurso na prática}

Na perspectiva textual-discursiva que adotamos, a linguagem é compreendida como constitutiva dos aspectos históricos e sociais dos sujeitos e de suas comunidades, bem como ação que coloca em interação seres humanos e realidades vivenciais, quer sejam mentais, sociais, naturais ou espirituais.

Duas assertivas importantes para o desenvolvimento tanto de análise de corpus quanto de atividades de ensino, a partir dos pressupostos teóricos dos estudos do texto e do discurso, são: a) o sujeito não é a origem do seu dizer; e b) as formas de dizer são reguladas (PÊCHEUX; FUCHS, 1997; ORLANDI, 1984).

Portanto, entende-se que o que dizemos emerge das relações sociais, culturais e históricas das quais participamos. Nossos valores, posicionamentos e os sentidos por nós produzidos são interacionais e não individuais, o que não retira a responsabilidade por aquilo que enunciamos, de forma escrita ou oral. Mesmo que o sujeito seja estratégico, crítico, reflexivo, suas verdades e suas ideologias são fruto da relação entre o interior e o exterior do ser humano. Nada emerge exclusivamente de nós mesmos.

Por conseguinte, os modos de dizer são regulados por convenções. Se não existimos isoladamente, se somos seres interacionais, há normas que organizam as nossas relações, caso contrário, viveríamos um caos interpretativo, em que cada um diria o 
que quer, da forma como quer e cada um se basearia no que bem entendesse. Sabemos que não é assim. Para viver em coletividade, é necessário ir ao encontro do outro, para isso, o uso convencional da linguagem é fundamental.

De acordo com Silva (2007, p. 385):

[a] palavra é o produto da relação recíproca entre falante e ouvinte, emissor e receptor. Cada palavra expressa o "um" em relação com o outro. Cada sujeito se atribui forma verbal a partir do ponto de vista da comunidade a que pertence e das experiências vividas. O Eu se constrói constituindo o Eu do outro e por ele é constituído.

Uma prática intercultural pressupõe a consideração da realidade sociolinguística da comunidade dos alunos e dos modos pelos quais eles produzem sentido e se relacionam com o seu cotidiano, o que permeia uma abordagem transdisciplinar dos processos comunicativos. Durante as atividades do projeto, a exemplo, compartilhamos via aplicativo WhatsApp notícias divulgadas em sites jornalísticos e vídeos disponibilizados em canais do YouTube sobre a degradação do meio ambiente e fotos de elementos naturais, como o mandacaru, cacto presente no semiárido nordestino.

As professoras regentes e os Xavante conversaram sobre os usos do mandacaru, que os indígenas desconheciam por não fazer parte do seu ambiente natural mais cotidiano. Estranharam a possibilidade de ser usado como alimento humano e um deles questionou: "Mas ela tem espinhas". Uma das professoras regentes explicou que os espinhos são retirados com faca e por dentro o mandacaru possui uma massa comestível. O mesmo aluno perguntou: "Gosto de quê msm?". A professora respondeu que a massa possui gosto amargo, semelhante ao da babosa. Essa conversa sobre um elemento natural de um território geográfico brasileiro foi introdutória à atividade proposta de descrever oralmente e, por escrito, alguns elementos da terra indígena em que viviam.

É certo que o meio ambiente é uma temática transversal contemporânea importante não apenas para os indígenas, nossos povos originais, mas a abordagem desse tema por indígenas permeia significados diferentes, tendo em vista que o eles compreendem a natureza como uma continuidade do seu próprio ser, mesmo após a morte, e nós, não indígenas, vivemos a natureza como se fosse uma realidade externa ao nosso eu interior.

Nas atividades transdisciplinares propostas procuramos valorizar o exercício da fala e escuta entre regentes e estudantes.

Não se trata de defender que, com a transdisciplinaridade, seria alcançada uma forma de anular o poder que todo saber implica, mas de acreditar na possibilidade de partilhar o poder que se tem, ou melhor, de desejar partilhá-lo, deixando de ocultar o saber que lhe corresponde, explicitando-o, tornando-o discursivo, dialógico. (SILVA; ROCHA, 2017, p. 4). 
Nota-se no enunciado "Gosto de quê msm?" o uso de uma linguagem informal e adequada ao suporte discursivo. Nas redes sociais, comumente, usam-se abreviações e o nosso grupo de alunos usava com frequência o WhatsApp em suas atividades comunicativas cotidianas, com mensagens não apenas no nosso grupo, mas mensagens privadas entre eles e publicação de status com frases prontas compartilhadas na internet, fotografias de suas famílias e comunidade, bem como vídeos de jogos de futebol na aldeia e festas.

Outra contribuição dos estudos do texto e do discurso para o ensino de português para indígenas é o trabalho com o texto enquanto objeto de estudo. O texto é a materialização da língua em seu uso verdadeiro, pois não nos comunicamos por meio de frases, mas através de textos (MARCUSCHI, 2012). O texto constitui uma unidade significativa e permite em sala de aula o posicionamento de alunos e professores sobre temas com diferentes graus de proximidade e vivência. A partir de textos multimodais foram compartilhados, construídos e reconstruídos valores e verdades, de forma oral e escrita, sobre política, economia, educação, saúde, alimentação e meio ambiente.

A prática pedagógica intercultural, entendida por nós de forma dialógica, pressupõe ainda a alternância de línguas (SILVA, 2007) com vistas a valorizar a manutenção da língua materna e a utilização da segunda língua como auxiliar nos processos de aprendizagem e interação com sujeitos não indígenas. Embora o nosso projeto não se caracterize como um ensino bilíngue, por se tratar de um curso de curta duração com objetivos mais específicos, indígenas e professoras regentes trocaram experiências linguísticas e culturais e assumiram a função de estudante e docente de modo dinâmico, em que por vezes eram os indígenas que ensinavam a língua Xavante.

Alguns vocábulos utilizados com frequência pelos alunos eram: Wêdi (usado como ok, certo, combinado), rówa'awê (bom dia), nõrî (partícula que indica coletivo, plural. Por exemplo: professora nõrî = professoras) e hepãri (obrigado).

O contato com os indígenas também permitiu às professoras regentes visualizarem na prática a importância de considerar os contextos de produção de um enunciado e a produção de efeitos de sentido coerentes a partir de construções sintáticas a priori superficial e normativamente classificadas como incoerentes, como nos exemplos a seguir:

[Trecho de interação via WhatsApp]

Xavante 1: As aulas é uma semana por dia??

Xavante 2: Pra mim de horários tantos faz Sou livre de horários disponíveis

Durante a organização dos dias e horários das aulas síncronas, foi solicitado aos indígenas que informassem as melhores opções de dias da semanas e horários pa- 
ra que pudéssemos garantir a presença virtual de todos nas atividades. O Xavante 1 constrói o seu enunciado alterando a localização lógica, de acordo com a língua portuguesa, dos lexemas semana e dia. Não é possível considerar a concepção de uma semana por dia, mas sim de um dia por semana. No entanto, a organização sintática não impediu a compreensão da pergunta elaborada.

O Xavante 2 elabora dois períodos, embora sem a demarcação de ponto final, que parecem semanticamente paradoxais. No primeiro período, ele afirma que pode ser determinado qualquer horário, pois os horários para ele não fazem diferença. No segundo período, informa ao leitor que é livre de horários disponíveis. Pode-se entender que alguém que é livre de horários disponíveis na verdade não possui horários disponíveis, já que está livre deles. A aproximação dos lexemas livre e disponíveis, no entanto, deixa o leitor em dúvida, pois liberdade e disponibilidade provocam um efeito de sentido de horários livres, horários disponíveis. A leitura do primeiro período permite a compreensão do segundo. Entende-se que o Xavante 2 possui horários livres e disponíveis para participar das aulas síncronas.

\section{Considerações finais}

Ao longo de séculos a língua portuguesa foi utilizada como instrumento colonizador dos povos indígenas e a tecnologia como mais um fator de distanciamento e exclusão de culturas. Nos dias atuais, entretanto, há uma mobilização nas aldeias para que as línguas originais sejam revitalizadas e usadas, de fato, como línguas maternas entre os mais jovens. Além disso, a aprendizagem da língua portuguesa padrão vem sendo incentivada como constituinte da luta política dos mais de 305 povos indígenas brasileiros ${ }^{1}$.

Ao passo em que muitos indígenas adentram cursos superiores, em 2017 se declararam indígenas 2.723 alunos calouros ${ }^{2}$, as comunidades se utilizam de mídias e recursos tecnológicos para divulgar suas culturas e compartilhar suas demandas. Em meio virtual há sites, blogs, rádios, canais no YouTube e contas no Instagram com conteúdos audiovisuais produzidos pelos povos originais.

Nessa mesma envergadura, há que se prever nas grades curriculares dos cursos superiores de Letras componentes curriculares que abordem a perspectiva intercultural, as especificidades de um ensino bilíngue e a diversidade indígena brasileira. Por certo, a alteridade entre academia e aldeia promove a produção de conhecimentos científico e pedagógico, mas também de conhecimento sobre relações humanas e relações com a natureza que podem ser empáticas e salutares.

\footnotetext{
2 Informação divulgada no site da Funai.

2 Informação do Inep divulgada no site da Agência Brasil.
} 


\section{Referências}

BRASIL. Ministério da Justiça e Segurança Pública. Fundação Nacional do Índio. Quem são. Disponível em: http://www.funai.gov.br/index.php/indios-no-brasil/quemsao. Acesso em: nov. 2020.

MARCUSCHI, L. A. Linguística de texto: o que é e como se faz? São Paulo: Parábola Editorial, 2012.

ORLANDI, E. P. Algumas considerações discursivas sobre a educação indígena. Em aberto, Brasília, v. 3., n. 21, p. 21-29, abr./jun. 1984. Disponível em: http:// rbepold. inep.gov.br/index.php/emaberto/article/view/1508. Acesso em: jan. 2020.

PÊCHEUX, M; FUCHS, C. A propósito da Análise Automática do Discurso: Atualização e perspectivas, 1975. In: GADET, F; HAK, T. Por uma Análise Automática do Discurso: Uma introdução à obra de Michel Pêcheux. Trad. Bethania S. Mariani et al. 3. ed. Campinas, SP: Unicamp, 1997. p. 163-246.

ROCHA, L. M.; SILVA, M. S. P. Educação bilíngue intercultural entre povos indígenas brasileiros. Revista UFG, Goiânia, v. 8, n. 2, p. 1-5, 2006, jul. 2017. Disponível em: https://www.revistas.ufg.br/revistaufg/article/view/48098. Acesso em: fev. 2020.

SILVA, M. S. P. da. As línguas indígenas na escola: da desvalorização à revitalização. Signótica, v. 18, n. 2, p. 381-395, 2006, 12 dez. 2007.

TOKARNIA, M. Ingresso de indígenas em faculdades é nove vezes maior do que em 2010. Agência Brasil. 2019. Disponível em: https://agenciabrasil.ebc.com.br/educacao/noticia/2019-04/ingresso-de-indigenas-em-faculdades-e-nove-vezes-maior-do-que-em-2010 >. Acesso em: nov. 2020. 


\section{DESAFIOS E NOVOS CAMINHOS DO ENSINO DE PORTUGUÊS COMO SEGUNDA LÍNGUA POR MEIO DE PLATAFORMAS DIGITAIS}

Katiele Ribeiro Oliveira Thaise Monteiro da Silva Melo

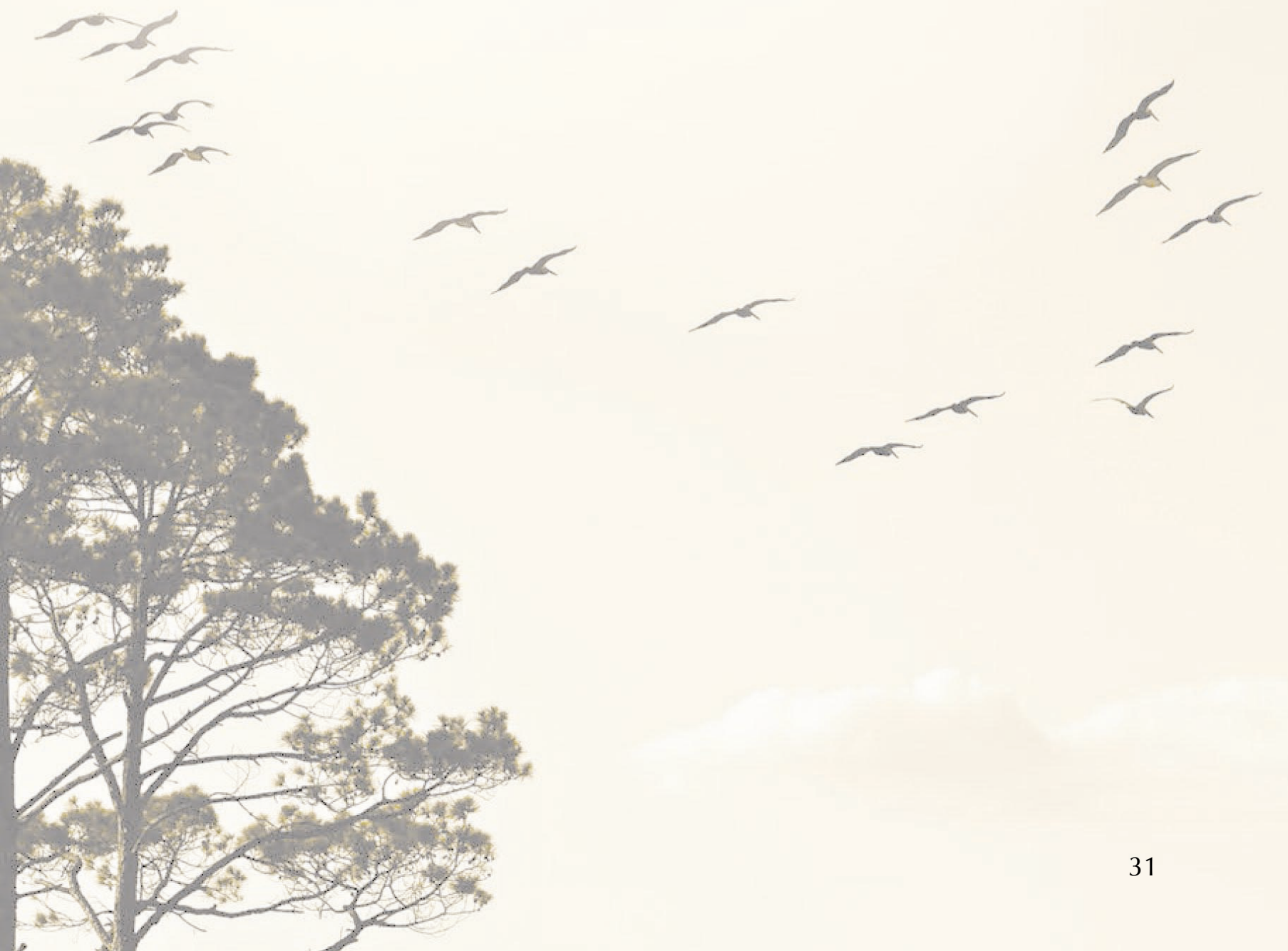


Resumo: O presente trabalho propõe discutir os desafios e as novas possibilidades de ensino de português como segunda língua, proporcionadas pela exigência das aulas remotas, realizadas por meio de plataformas digitais, em que o ensino a distância se apresenta como uma alternativa às aulas presenciais, em decorrência da pandemia causada pelo coronavírus (Covid-19). Para tanto, são apresentados alguns aspectos de uma experiência docente realizada por Katiele Ribeiro Oliveira, aluna do curso de Letras: Licenciatura em Língua Portuguesa, do Instituto Federal de Goiás, câmpus Goiânia, observando como é possível o ensino-aprendizagem da língua mesmo em uma situação adversa. As aulas foram ministradas às terças e quintas-feiras, das $16 \mathrm{~h}$ às $17 \mathrm{~h} 30$ - encontros de uma hora e meia - a um grupo de 12 alunos estrangeiros, residentes em Goiânia, inscritos no Pré PEC-G (Programa de Estudantes-Convênio de Graduação), que estudam português com intuito de obter o Certificado de Proficiência em Língua Portuguesa para estrangeiros (CELPE-Bras), para poderem ingressar no ensino superior em universidades brasileiras. As aulas foram realizadas na modalidade síncrona, por meio da plataforma de webconferência Google Meet, utilizando-se, também, da plataforma digital Google Classroom, como ambiente virtual de sala de aula, para a realização de atividades. Outra ferramenta utilizada foi o aplicativo WhatsApp, um canal de comunicação direta, útil na interação entre professoras-regentes e alunos, permitindo a postagem de atividades orais e escritas para a prática da língua portuguesa.

Palavras-chave: Ensino. Língua portuguesa. Alunos estrangeiros. Plataformas digitais.

\section{Introdução}

Este trabalho tem o objetivo de apresentar algumas experiências do ensino

Ede português como segunda língua (PL2). Estes relatos partem dos desdobramentos do Projeto MoVe - Movimentos Migratórios em V: português para falantes de outras línguas, coordenado pelas professoras Suelene Vaz da Silva e Cleide Araújo Machado.

O projeto em questão atendeu alunos do (PLAC) - Português como Língua de Acolhimento e do (PEC-G) - Programa de Estudantes-Convênio de Graduação. O primeiro refere-se a estrangeiros que vieram para o Brasil de forma permanente, e o segundo é voltado a alunos que vieram com o intuito de estudar e voltar para os seus países, tendo uma estadia temporária no Brasil. O projeto atendeu ainda indígenas brasileiros da comunidade Xavante.

Os relatos citados aqui são apenas do grupo Pré PEC-G A2. O termo 'Pré' indica que os alunos estão participando de um curso preparatório, pois os estrangeiros que não obtiveram o certificado de proficiência em língua portuguesa em seus países de origem podem realizá-lo em uma instituição conveniada ao programa no Brasil. Já o termo 'A2' é outra classificação feita pela coordenação do projeto para melhor organizar os grupos de alunos pelo nível de conhecimento que tinham do português.

O Pré PEC-G A2, turma pela qual ficamos responsáveis, foi integrada por 12 alunos, todos do continente africano, mais especificamente dos seguintes países: Gui- 
né - Equatorial, Benin, Camarões, Senegal, Gabão e Congo. A grande maioria era falante do francês, mas falavam também línguas como: Fon, Goun, Peulh e Xlá (línguas informadas pelos alunos no ato da inscrição).

Este trabalho retrata um estudo qualitativo recorrendo à observação das aulas, o desempenho dos alunos, as melhorias apresentadas e várias reflexões acerca do Ensino Emergencial e do Ensino a Distância - EaD - com os usos das plataformas digitais no processo de ensino-aprendizagem da língua. Além disso, fizemos a revisão de algumas literaturas de forma sintética, pois o objetivo deste artigo são os relatos das experiências, apresentando os desafios e os novos caminhos a serem traçados no ensino de PL2 por meio de plataformas digitais.

A fundamentação teórica deste estudo envolve Harari (2019), por meio do qual discutiremos sobre a importância da língua no processo de comunicação, Ferreira e Azevedo (s/d), Pereira e Moraes (2009), Moore e Kearsley (2007), entre outros, para ampliarmos a discussão sobre o PL2 e dar sustentação aos nossos relatos.

A relevância do presente relato está no fato de que ele comprova que o ensino do PL2, de forma remota, por meio de plataformas digitais, numa situação de pandemia, é possível e pode ser eficaz.

\section{A língua e o PL2}

O ensino do português no Brasil inicia-se desde o processo de colonização do país e os Jesuítas foram grandes responsáveis pela disseminação da língua. De acordo com Rocha (2019, p. 103) "no período Colonial, a língua portuguesa e o latim eram vistas como línguas estrangeiras para os índios. Sendo os jesuítas os pioneiros no ensino destas línguas, em contrapartida, vão ser também os aprendizes das línguas nativas". Entretanto, o ensino de português com o passar do tempo foi ganhando outros objetivos, já não estamos falando mais de um processo de colonização, nem do uso da língua como instrumento de poder, mas do ensino de português com objetivos sociais e humanitários.

É consenso científico de que há aproximadamente 70 mil anos a nossa espécie, Homo sapiens, começou a elaborar movimentos comuns coletivos que resultaram no que chamamos de cultura. O que nos distingue das demais espécies não é a força, a maior parte dos grandes primatas é mais eficiente neste quesito, nem tampouco a capacidade de caça, durante milhares de anos fomos as presas e não o contrário. $\mathrm{O}$ nosso diferencial foi o desenvolvimento da fala, a capacidade de se comunicar com o semelhante, expressar sentimentos, necessidades, emitir alertas de perigo e principalmente juntar esforços na defesa dos iguais.

Segundo Harari (2019), a Revolução Cognitiva possibilitou ao Homo sapiens formar bandos maiores e mais estáveis, fato que culmina com a fundação de pequenas vilas ou aldeias e posteriormente nas grandes cidades. Uma família de chimpan- 
zés pode chegar a 50 indivíduos, no entanto, todas as relações são lastreadas pelo contato físico, se o bando cresce, o líder perde o controle e o bando se divide. Já o Homo sapiens somente conseguiu ultrapassar esse limite com o desenvolvimento da fala, que possibilitou a cooperação de mais indivíduos para a realização de tarefas complexas e a mudança no comportamento e padrão social.

A língua sempre foi utilizada como ferramenta de domínio, ao avançarmos na história inúmeros são os exemplos disso. Ao dominar uma região, o Império Romano mantinha os líderes tribais locais no controle da área conquistada, mas impunha seu idioma oficialmente. No Brasil não foi diferente, os padres jesuítas fundaram as 'Missões' para catequizar os nativos indígenas e ensinar-lhes o português.

O decorrer dos séculos não diminuiu a importância da fala para o Homo sapiens, ao contrário, o surgimento da escrita, do comércio, da democracia e de todos os traços culturais somente foi possível a partir da conquista do aumento da capacidade cognitiva. Segundo Harari (2019) foi a língua que nos possibilitou criar 'verdades imaginárias' e transmiti-las às futuras gerações.

Quando um indivíduo adentra uma nova fronteira territorial, seja para residir, passear, estudar ou negociar, é extremamente necessário o domínio dos códigos linguísticos regionais, isto porque ser e fazer-se entendido é condição básica existencial das relações humanas.

O projeto MoVe tem por intenção gerar a conexão entre os imigrantes advindos de diversos países e a cultura local, por meio do ensino da língua portuguesa, possibilitando a integração do indivíduo à comunidade e ao meio acadêmico.

O site do Ministério da Educação (2020) informa, a respeito do PEC-G, programa no qual nossos alunos estão inseridos, que:

[o] Programa de Estudantes-Convênio de Graduação (PEC-G) oferece oportunidades de formação superior a cidadãos de países em desenvolvimento com os quais o Brasil mantém acordos educacionais e culturais. Desenvolvido pelos ministérios das Relações Exteriores e da Educação, em parceria com universidades públicas - federais e estaduais - e particulares, o PEC-G seleciona estrangeiros, entre 18 e preferencialmente até 23 anos, com ensino médio completo, para realizar estudos de graduação no país.

Dessa maneira, o programa permite uma grande conexão entre países africanos e o Brasil. Nesse processo a língua é um elemento integrador e facilitador. A língua torna-se o elo que permitirá que estudantes estrangeiros possam se conectar.

Nossa experiência docente foi com o ensino de PL2, mas existem várias nomenclaturas que designam o ensino da língua de acordo com as suas especificidades. De acordo com Ferreira e Azevedo (s/d, p. 5-6), existem nomenclaturas como:

Português Língua Estrangeira (PLE), Português Segunda Língua (PL2) para aqueles que possuem uma primeira língua, considerada materna; Português para Fa- 
lantes de Outras Línguas (PFOL), que pode ser considerado mais abrangente e favorecer o destaque para a ampliação do interesse de pessoas oriundas de outros países pelo português; Português como Língua Adicional (PLA), concepção alinhada aos que aprendem português em adição a outras línguas que já fazem parte de seu repertório, como as comunidades indígenas e surdas; Português Língua de Herança (PLH), voltado aos filhos de falantes dessa língua quando residem fora de seu país de origem e que tem o compromisso de resgatar os valores culturais associados à língua.

Trataremos, no tópico a seguir, dos meios utilizados para o ensino da PL2 e de seus desafios.

\section{Plataformas digitais: desafios e as novas possibilidades da educação a distância no Brasil}

A educação a distância é cercada de dúvidas, preocupações em relação à qualidade, à autonomia dos estudantes, entre outros aspectos, mas, por outro lado, segundo Pereira e Moraes (2009, p. 65):

[a] educação a distância rompe com a relação espaço/tempo, que tem caracterizado a escola convencional, e se concretiza por intermédio da comunicação mediada, por meio da mídia. Diferentemente de uma situação de aprendizagem presencial, onde a mediação pedagógica é realizada pelo professor em contato direto com os alunos, na modalidade a distância a mídia torna-se uma necessidade absoluta para que se concretize a comunicação educacional.

Nesse sentido, essa modalidade de ensino 'rompe com a relação espaço/tempo', o que, em uma pandemia, em que as pessoas precisam ficar isoladas, torna-se um elemento de comunicação extremamente importante e desafiador, devido à necessidade de dissociação das aulas tradicionais/presenciais.

A história da EaD passa por vários momentos. Para Moore e Kearsley (2007 apud COSTA, 2017, p. 65), esse modelo de ensino pode ser classificado em gerações:

$1^{a}$ Geração: marcada pela comunicação textual, por meio de correspondência; $2^{\text {a }}$ Geração: ensino por rádio e televisão; $3^{\mathbf{a}}$ Geração: caracterizada, principalmente, pela invenção das universidades abertas; $4^{\text {a }}$ Geração: marcada pela interação à distância em tempo real, em cursos de áudio e videoconferências; $\mathbf{5}^{\mathbf{a}}$ Geração: envolve o ensino e o aprendizado on-line, em classes e universidades virtuais, baseadas em tecnologias da internet.

Para a concretização do projeto MoVe, foram utilizadas duas plataformas principais: Google Meet e Google Classroom, posteriormente também foi utilizado o WhatsApp como auxílio na comunicação com os alunos. Cada uma desempenhou um papel importante no processo de ensino-aprendizagem. 
O material básico utilizado nas aulas intitula-se Pode entrar: Português do Brasil para refugiadas e refugiados (ver Figura 1), uma produção feita em parceria entre o Curso Popular Mafalda, o Alto Comissariado das Nações Unidas para Refugiados (Acnur) e a Cáritas Arquidiocesana de São Paulo (Casp). A apostila foi preparada visando ao ensino de português para refugiados, com um material que considera desde as necessidades básicas de comunicação, como saudações, localização, meios de transporte, produção de textos, uso da gramática, até questões culturais brasileiras mais complexas. O material, que está disponível de forma digital no site do Instituto Nacional de Estudos e Pesquisas Educacionais Anísio Teixeira (Inep), foi disponibilizado por nós aos nossos alunos por e-mail e ainda foi dada a cada aluno uma versão impressa.

Figura 1. Livro Pode entrar: Português do Brasil para refugiadas e refugiados

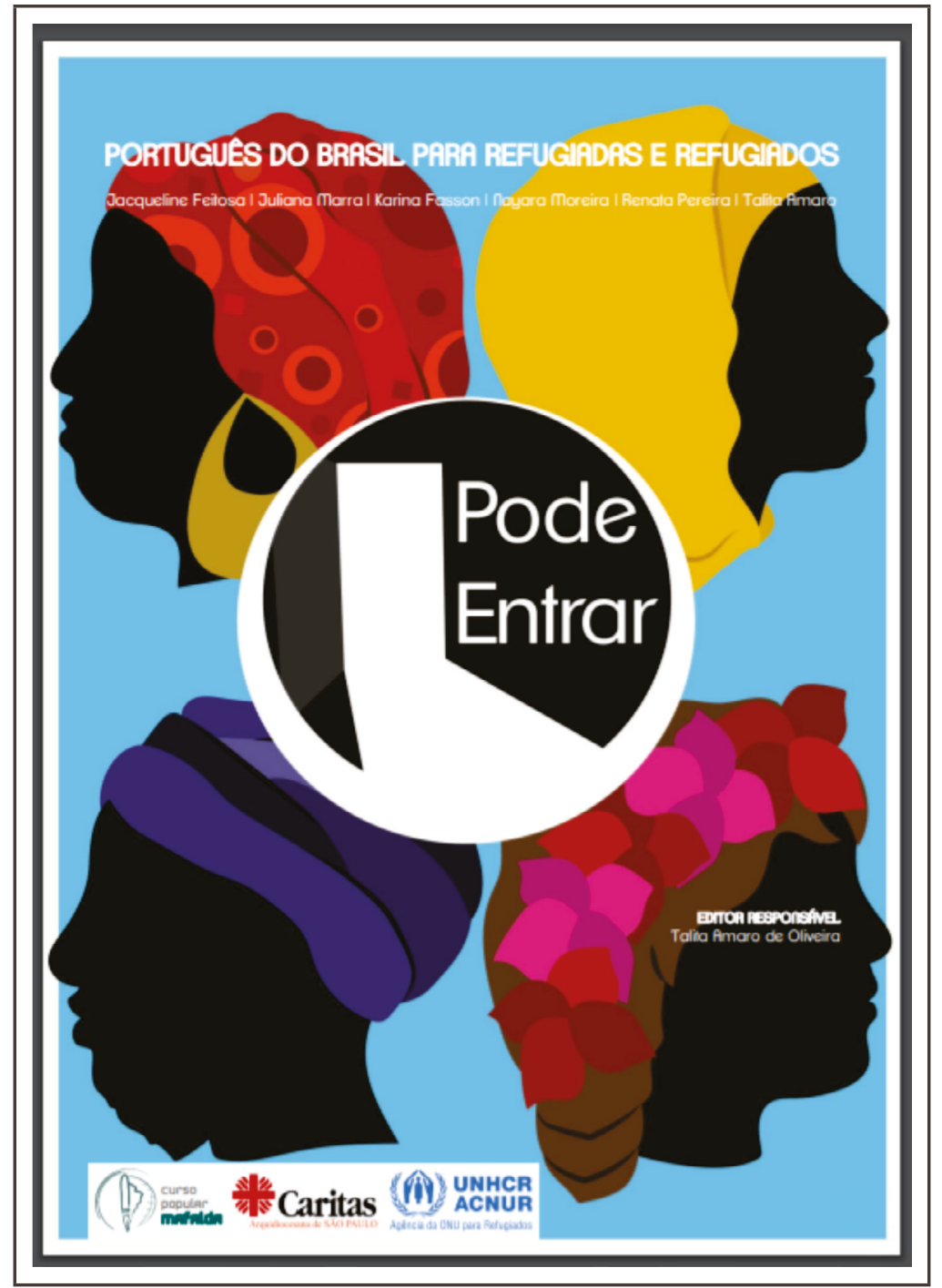

Fonte: https://www.acnur.org/portugues/wp-content/uploads/ 2018/02/Pode_Entrar_ACNUR-2015.pdf 
Embora os integrantes do PEC-G não estejam em condições de refugiados, já que vieram para estudar, o uso do livro foi extremamente importante para o desenvolvimento da fala e da escrita dos alunos, apesar de as aulas sempre extrapolarem os limites do seu conteúdo, pois eram guiadas de acordo com as necessidades que os alunos apresentaram durante o curso.

Além do supracitado material, também foi usado em algumas aulas o livro 'Português para estrangeiros II: Nível intermediário', de Weiss (2017). O material em questão é um compilado de atividades, textos, letras de músicas e gramática com um aprofundamento maior.

Acerca dos desafios enfrentados, destaco que o ensino remoto emergencial trouxe uma nova perspectiva para mim enquanto licencianda regente. $\mathrm{O}$ ensino do português para um não nativo requer muita habilidade com a fonética, com exemplos práticos e objetivos. Também é importante ressaltar desafios com questões como a variedade linguística no Brasil, bem como as diferenças entre linguagens formal e informal.

Sobre as novas possibilidades de ensino remoto, ressalto ainda a importância de um aprofundamento e muito treino com as ferramentas tecnológicas. Durante as aulas observamos inclusive que é possível ampliar o ensino por meio de jogos. Percebemos que a grande dificuldade é encontrar sites e materiais adequados, que atendam às necessidades dos alunos.

\section{Apresentação de dados}

Os dados apresentados a seguir são baseados na observação contínua das aulas pelo Google Meet, Classroom e WhatsApp e em relatórios escritos ao final de cada encontro on-line.

\section{Relatos das aulas síncronas pelo Google Meet}

O Google Meet (ver Figura 2) é um serviço disponibilizado pelo Google, por meio do qual podem ser realizadas videoconferências, gravação de reuniões e transmissão ao vivo. O uso dessa plataforma deu-se a partir de instruções prévias da coordenação do projeto feitas aos professores regentes, sobre o funcionamento da plataforma e suas ferramentas, bem como a partir de esclarecimento de dúvidas.

Em um primeiro momento, os alunos do Pré PEC-G A2 não tiveram dificuldades, mas no decorrer do curso foram observados alguns problemas menos em relação às ferramentas e mais relacionados à conexão, qualidade da internet. Vale salientar que os alunos recebiam uma pequena ajuda de custo mensal, para auxiliá-los na contratação de dados de internet. Com carga horária de três horas semanais, as aulas aconteciam duas vezes por semana, com duração de 90 minutos. 
Figura 2. Representação de uma reunião pelo Google Meet

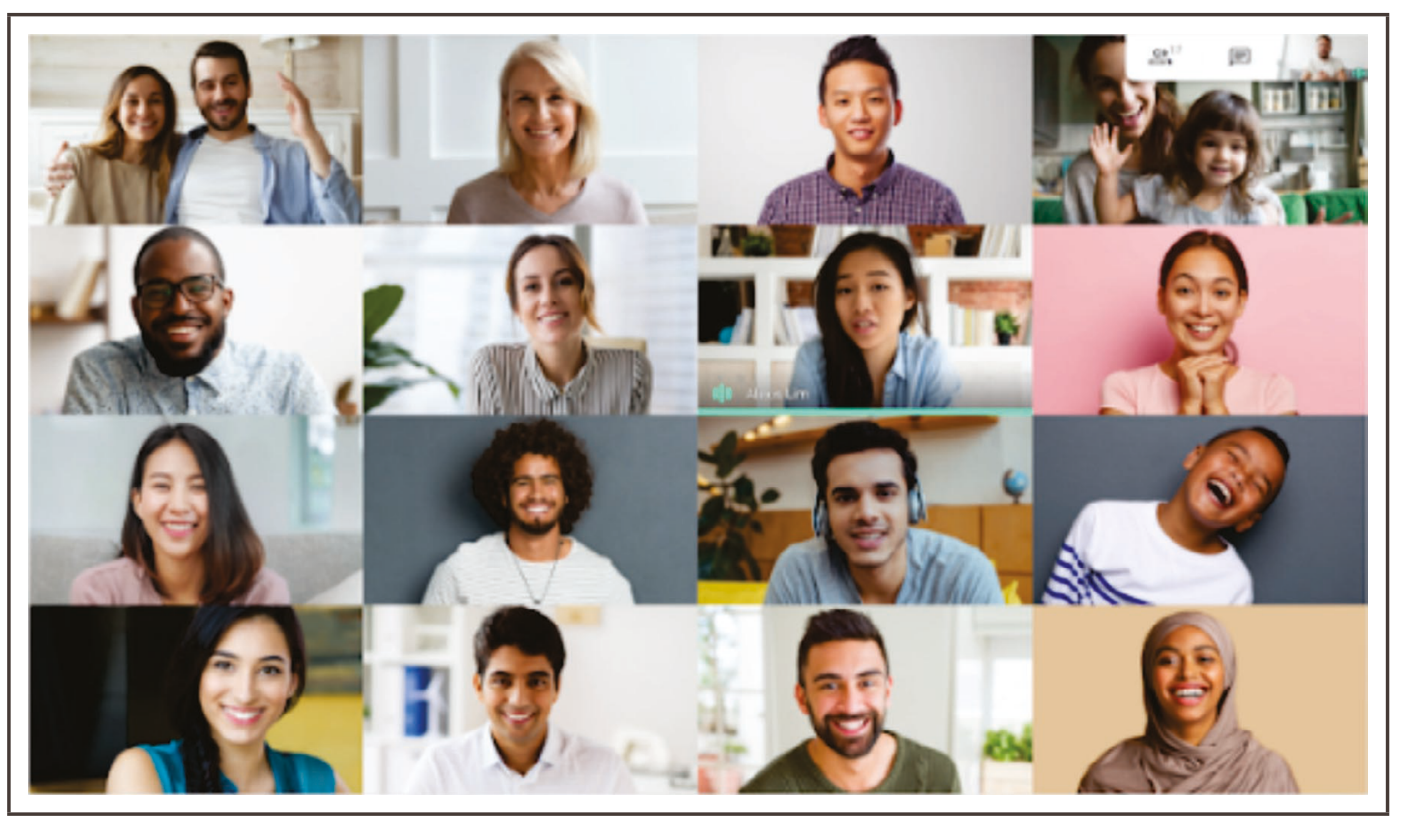

Fonte: Google Workspace.

Os alunos sempre eram curiosos, perguntavam pelo chat e interagiam. A interação se dava de forma mais efetiva quando a aula era preparada para dar 'voz' a eles. Uma das observações que fazemos é que os alunos demonstraram grande necessidade de dialogar mais nas aulas, talvez pelo fato de estarmos em um isolamento e o contexto da pandemia não permitisse uma interação maior com brasileiros presencialmente.

Além disso, percebemos que os alunos eram pontuais, sempre participavam quando eram instigados a falar, entretanto quase nunca abriam as suas câmeras para que fossem vistos, usavam apenas a função do áudio no Google Meet.

Umas das grandes dificuldades de apresentar a gramática era colocá-la em contexto, entretanto, depois de várias buscas e pesquisas, tornou-se mais fácil (utilizamos textos variados que foram tirados dos livros citados anteriormente).

O conteúdo das aulas era preparado, geralmente, com exposição de slides do Power Point (percebemos que é importante fazer uso de formas diferentes de apresentar, por exemplo, com o uso do Genially ${ }^{1}$ e Prezzi ${ }^{2}$ ), entretanto, durante o período das aulas, não foram utilizados, pois sentimos dificuldades no acesso pela nossa falta de domínio.

1 Genially: Plataforma que permite apresentações infográficas, dossiers, apresentações de Vídeo, Posters, CVS, Quizzes, etc. Disponível em: https://www.genial.ly/?gclid=CjwKCAjw5p_8BRBUEiwAPp JO6_F_9lmAHx8Vb8Nw52NCLISERkIS238HeQIP7Jm_fgnuksEs5kmSPhoCcw4QAvD_BwE. Acesso em: 13 out. 2020.

2 Prezzi: Plataforma/aplicativo que permite criar apresentações mais organizadas, interativas e persuasivas. Disponível em: https://prezi.com/pt/. Acesso em: 13 out. 2020. 


\section{Relatos das atividades lançadas no Classroom}

As atividades desenvolvidas no Google Classroom tinham o intuito de fazer com que os alunos exercitassem a escrita, tivessem acesso a links de arquivos selecionados, como filmes, músicas, sites sobre a gramática, vídeos interativos, etc. Além disso, por meio do Classroom os alunos podiam receber feedbacks individualizados. A figura 3 apresenta um print da postagem de boas-vindas aos alunos, explicando sobre horários, a duração do curso e disponibilizando links com vídeos explanando sobre como usar o Google Meet e o Google Classroom pelo computador e pelo celular. Percebemos, no decorrer do curso, que praticamente todos os alunos tinham acesso às aulas por meio de seus celulares.

Figura 3. Print da postagem de boas-vindas

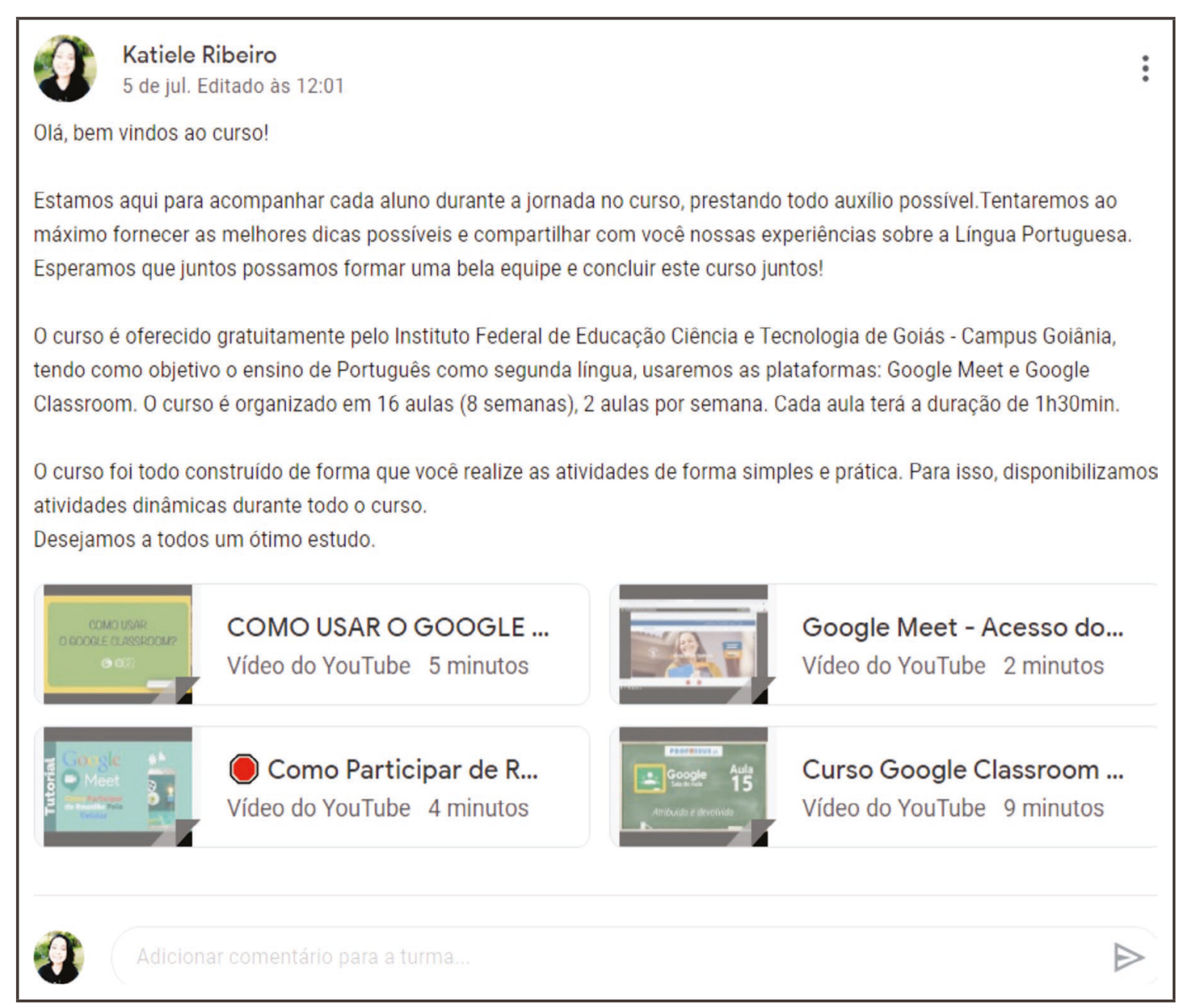

Fonte: Material desenvolvido pelas autoras (2020).

Foram lançadas, entre os meses de julho e outubro, oito atividades. A primeira exigia do aluno que digitasse em língua portuguesa e falasse sobre algumas informações pessoais, como nome completo, nacionalidade, data de nascimento, 
idade, o nome dos pais, qual curso superior iria cursar no Brasil, entre outras. Nessa atividade, percebemos que as dificuldades encontradas na escrita, de modo geral, eram:

- conjugação dos verbos no presente e passado;

- uso de preposições e suas contrações: 'no' e 'na', 'do' e 'da', etc.

- diferença entre 'que' e 'quem';

- uso da inicial maiúscula, inclusive em nomes próprios, etc.

As correções eram individuais e cada aluno recebia dicas de como melhorar a escrita. Quando necessário, deixávamos algum link para acesso e estudo posterior. Ademais, citaremos outras atividades que julgamos terem sido relevantes.

As atividades lançadas na plataforma eram sobre verbos, pronomes, adjetivos pátrios e, além disso, envolviam muitos exercícios de escrita, com assuntos como 'sociedade e educação', 'os direitos das crianças', 'igualdade de gênero', 'transporte público', 'respeito às pessoas diferentes', 'saúde e o SUS', 'liberdade de crença', temas propostos pela já mencionada apostila da Acnur. Todos os tópicos foram trabalhados pensando na realidade dos alunos, no contexto em que estavam inseridos, levando em conta, ainda, questões interculturais.

Em relação aos métodos de avaliação utilizados, podemos citar que não existia um sistema de atividades/prova com nota, mas sim atividades com feedbacks (Figuras 4 e 5) indicando ao aluno como ele poderia melhorar.

As atividades eram voltadas às necessidades dos alunos, por exemplo, se alguns tinham dificuldade no uso dos pronomes possessivos, então esse seria o tópico trabaIhado. Embora tenhamos seguido a ordem do livro Pode entrar: Português do Brasil para refugiadas e refugiados, sempre procuramos sanar as dificuldades apresentadas, ao longo das aulas, buscando novos materiais.

Figura 4. Feedback realizado para um dos alunos sobre a atividade 8

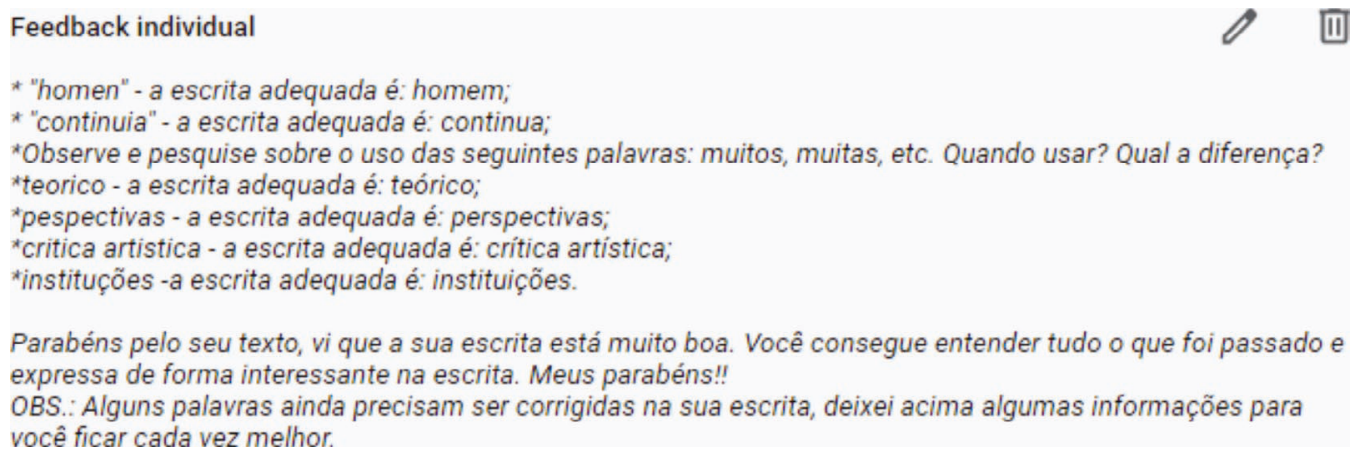


Figura 5. Exercício de escrita postada no Classroom

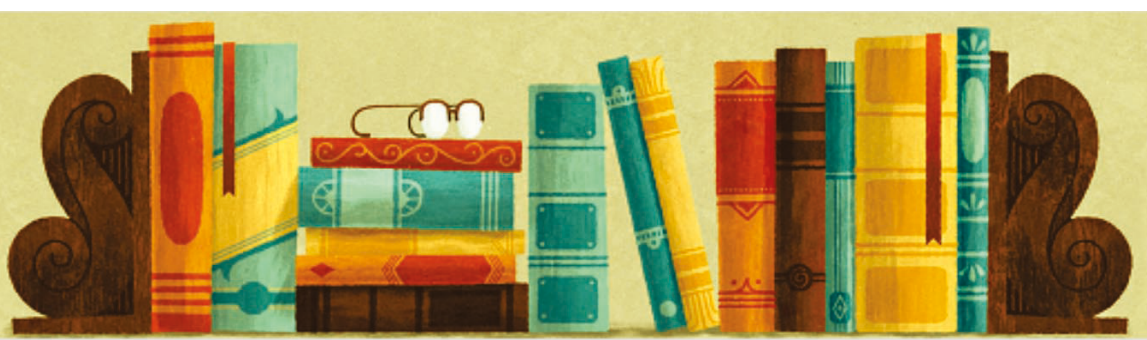

\section{Atividade 8 - Exercício de escrita}

${ }^{*}$ Aguarde a devolução da sua atividade corrigida.

* Qualquer dúvida consulte o material de estudo, a internet ou nos pergunte pelo Whatsapp.

*Obrigatório

Endereço de e-mail *

Seu e-mail

Exercicio (CELPE-BRAS - adaptado) - Você vai assistir ao video, podendo fazer anotações enquanto assiste. Imagine que você trabalha na UFRGS e é o responsável por escrever a apresentação dos cursos para o site da universidade. Com base no video que você assistiu, escreva a apresentação do curso de História da Arte, mencionando a história do curso, o que é estudado durante a graduação e as perspectivas de atuação profissional dos formados em História da Arte. Link usado na elaboração da atividade -

http://download.inep.gov.br/outras_acoes/celpe_bras/provas/2019/prova_2019_1 edicao.pdf

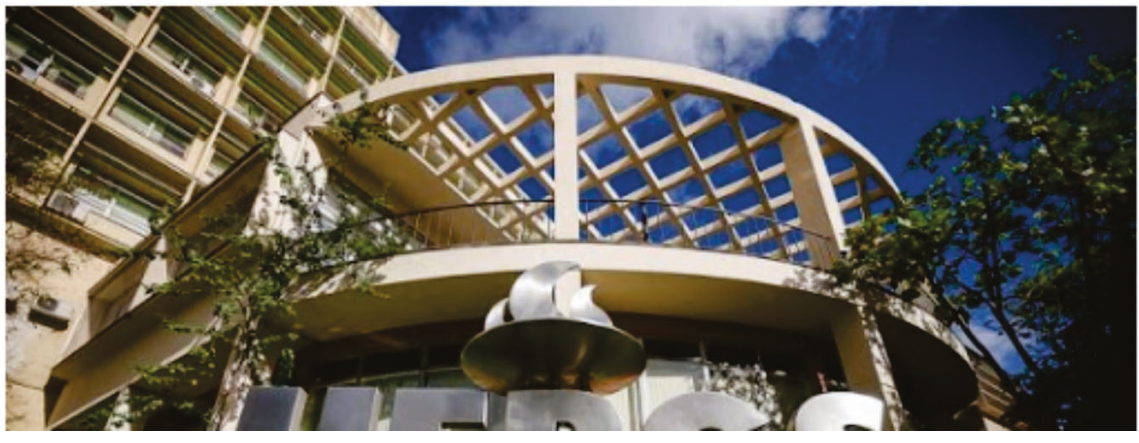

Fonte: Material desenvolvido pelas autoras (2020). 


\section{Relatos das atividades propostas no WhatsApp}

O WhatsApp (Figura 6) é um serviço de comunicação rápida utilizado por mais de dois bilhões de pessoas no mundo inteiro, por meio dele é possível o envio de mensagens instantâneas, vídeos, links, áudios, realizar chamadas de áudio e vídeo. Trata-se de uma ferramenta muito completa, que auxiliou bastante na interação com os estudantes do Pré PEC-G A2.

Nesse aplicativo, foram desenvolvidas atividades em que os alunos tinham que exercitar tanto a escrita como a fala, por exemplo: receitas de pratos típicos dos seus países, áudios com apresentação pessoal física e psicológica, etc.

Figura 6. Exemplo de grupo criado no WhatsApp

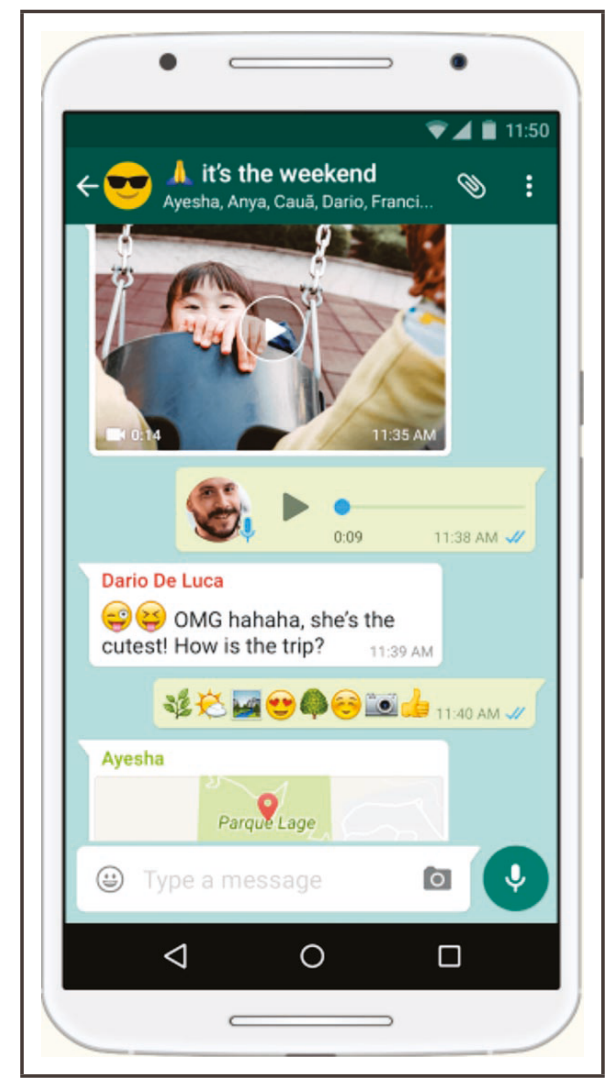

Fonte: WhatsApp.

Na Figura 7, há uma proposta de atividade feita pela professora orientadora Thaise Monteiro da Silva Melo, já na figura 8, temos um dos alunos participando da atividade proposta pelo aplicativo. Nela, o aluno precisava fazer uma apresentação física e psicológica. Os alunos, de modo geral, demonstraram habilidade com a articulação das palavras e quando surgia alguma dificuldade eram auxiliados imediatamente. 
Figura 7. Proposta de atividade 1

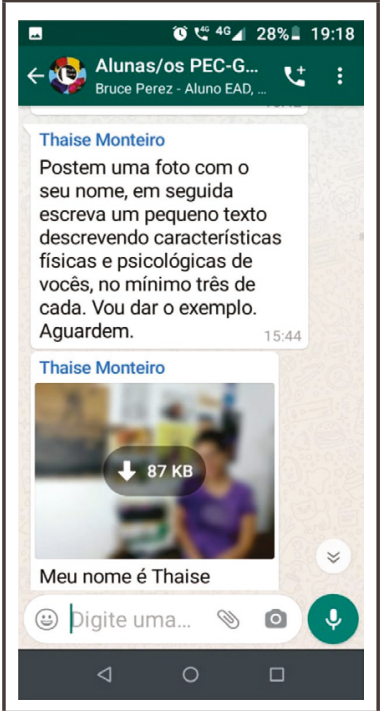

Fonte: A autora (2020).
Figura 8. Participação de um dos alunos

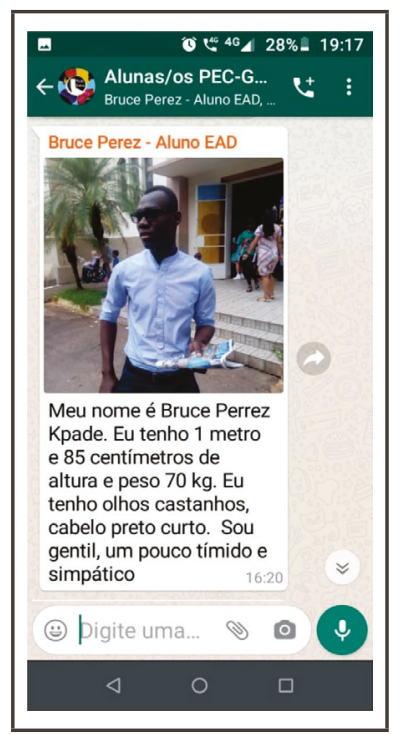

Fonte: A autora (2020).

Logo abaixo, na figura 9, é possível ver outra atividade básica desenvolvida pelo WhatsApp. Nela, o aluno precisava digitar o nome completo e posteriormente enviar um áudio soletrando as letras. Essa atividade exigiu dos alunos o conhecimento da pronúncia adequada das letras do alfabeto. Na atividade da figura 10, os alunos tinham que pesquisar a receita do prato de comida de que mais gostavam, com ingredientes e modo de preparo. A receita deveria ser compartilhada por meio de texto escrito e de áudio. Notamos a presença de vários pratos típicos dos seus países de origem.

Figura 9. Proposta de atividade 2

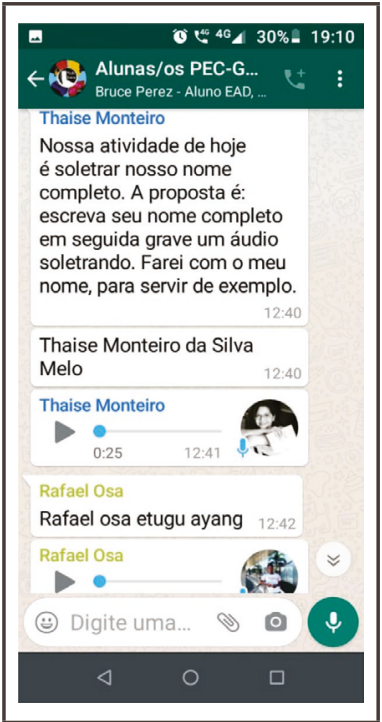

Fonte: A autora (2020).
Figura 10. Proposta de atividade 3

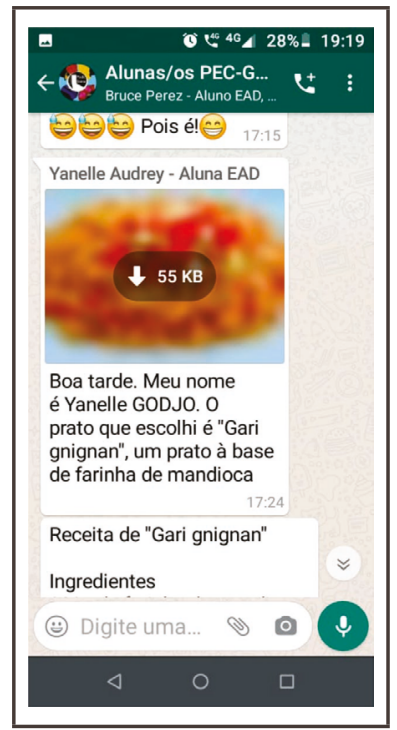

Fonte: A autora (2020). 


\section{Considerações finais}

Por meio do projeto MoVe foi possível ter essa experiência única de interculturalidade e que permitiu aos alunos acesso maior à língua portuguesa em período de isolamento social. As experiências adquiridas servirão de reflexão e questionamentos sobre o que ainda pode ser feito, sobre como ter uma prática pedagógica cada vez mais eficiente, dinâmica e que abarque as necessidades dos alunos.

Consideramos que o projeto foi de grande importância na vida dos alunos do Pré PEC-G A2. Eles demonstraram melhorias na fala e na escrita ao longo curso, dúvidas eram tiradas a todo momento e o esforço deles era admirável. Além disso, é importante ressaltar que pelo nível de português que possuem atualmente, desenvolvido ao longo do projeto, certamente se sairão muito bem na prova Celpe-Bras. É o que desejamos.

O uso da tecnologia foi desafiador, inovador e significativo para a nossa experiência enquanto docentes. Percebemos que há uma necessidade cada vez maior do domínio da tecnologia de modo geral, mais especificamente de formas dinâmicas e mais didáticas em aulas remotas. Percebemos também que o esforço do aluno precisa ser ainda maior nessa modalidade de ensino, pois, diante de aparelhos eletrônicos e plataformas digitais, o contato presencial não existe e com o tempo das aulas remotas síncronas, pelo Google Meet, menor do que as aulas assíncronas, pelo Google Classroom, o aluno precisa de mais autonomia.

\section{Referências}

BRASIL. Ministério da Educação. PEC - G. Disponível em: http://portal.mec.gov.br/ pec-g. Acesso em: 8 out. 2020.

COSTA, A. R. A educação a distância no Brasil: Concepções, histórico e bases legais. Revista Científica da FASETE, p. 59-74, 2017.1 Disponível em: https://www.unirios. edu.br/revistarios/media/revistas/2017/12/a_educacao_a_distancia_no_brasil_concepcoes_historico_e_bases_legais.pdf. Acesso em: 29 set. 2020.

FEITOSA, J.; MARRA, J.; FASSON, K.; MOREIRA, N.; PEREIRA, R.; AMARO, T. Pode Entrar: português do Brasil para refugiados e refugiadas. Curso Popular Mafalda, Caritas, ACNUR. São Paulo, 2015. Disponível em: https://www.acnur.org/portugues/wp-content/uploads/2018/02/Pode_Entrar_ACNUR-2015.pdf. Acesso em: 3 out. 2020.

FERREIRA, M. S.; AZEVEDO, I. C. M. Formação de professores de português como língua estrangeira: necessidades e desafios. In: $9^{\circ}$ Encontro Internacional de Formação de Professores / 10 FOPIE, 2016, Aracaju. Anais [...]. Aracaju: Grupo Tiradentes, 
v. 9. p. 1-14, 2016. Disponível em: https://eventos.set.edu.br/enfope/article/viewFile/2353/477. Acesso em: 12 out. 2020.

GOOGLE. Google Meet. Disponível em: https://workspace.google.com.br/intl/pt-BR/ products/meet/. Acesso em: 12 out. 2020.

GOOGLE. WhatsApp: recursos. Disponível em: https://www.whatsapp.com/features/. Acesso em: 10 out. 2020.

HARARI, Y. N. Sapiens: Uma breve história da humanidade. Porto Alegre: L\&PM Editores S. A., 2019.

PEREIRA, E. W.; MORAES, R. de A. História da educação a distância e os desafios na formação de professores no Brasil. In: SOUZA, A. M. de; FIORENTINI, L. M. R.; RODRIGUES, M. A. M. (orgs.). Educação a distância: comunidade de aprendizagem em rede. Brasília: Universidade de Brasília, Faculdade de Educação, 2009. p. 6589. Disponível em: http://files.fernandaunb.webnode.com/2000000077ed3980be7/ Hist\%C3\%B3ria\%20da\%20EaD.PDF. Acesso em: 3 out. 2020.

ROCHA, N. A. O ensino de Português língua estrangeira no Brasil: ontem e hoje. Linguagens - Revista de Letras, Artes e Comunicação Blumenau, v. 13, n. 1, p. 101-114, jan./abr. 2019. ISSN 1981-9943. Disponível em: https://proxy.furb.br/ojs/index.php/ linguagens/article/view/8401/4546.Acesso em: 8 out. 2020.

WEISS, D. B. Português para estrangeiros II: Nível intermediário. UFJF, 2017. Disponível em: https://oportuguesdobrasil.files.wordpress.com/2018/03/portuguc3aas-para-estrangeiros-ii-2017-textos.pdf. Acesso em: 12 out. 2020. 


\section{A IMPORTÂNCIA DAS TROCAS CULTURAIS NO PROCESSO DE ENSINO-APRENDIZAGEM DE PORTUGUÊS COMO SEGUNDA LÍNGUA: EXPERIÊNCIAS EM UMA TURMA DE PRÉ-PEC-G}

Lívia Regina Borges Pereira Mariana Alves de Oliveira Thalía Marques de Andrade Paula Graciano Pereira

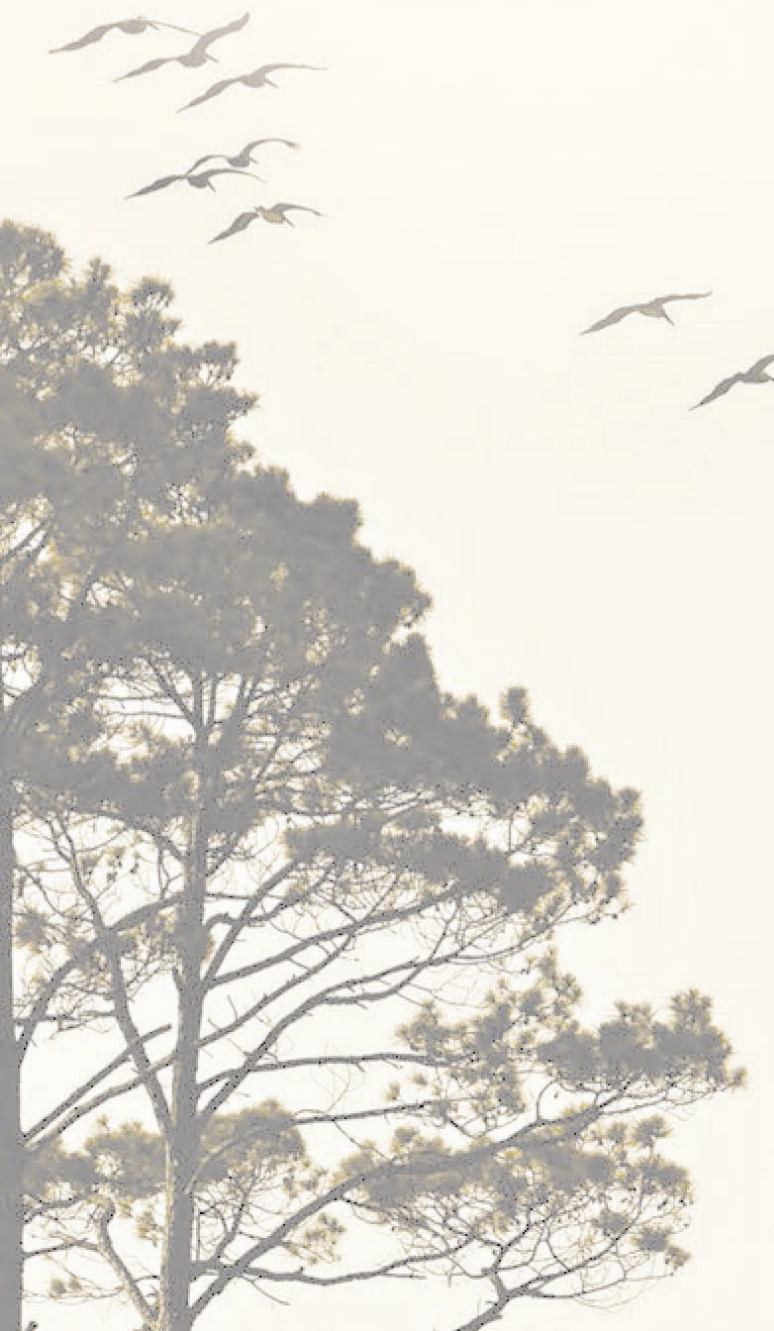


Resumo: Este artigo tem por objetivo apresentar aspectos da experiência de ensino-aprendizagem de português como segunda língua em uma turma de Pré-PEC-G, especialmente no que se refere a trocas culturais entre estudantes de múltiplas nacionalidades e entre os discentes e as professoras brasileiras. Entendemos que língua e cultura são construtos indissociáveis e assumimos uma perspectiva multi/interculturalista a partir dos estudos teórico de Andrade (2009), Candau (2008), Lelles, Silva e Freitas (2014), Vygotsky (1991, 1998) entre outros. Apresentamos e refletimos sobre algumas experiências vivenciadas especificamente em duas aulas, descrevendo como ocorreram as trocas culturais e mostrando trechos de interações orais e tarefas escritas dos estudantes. Acreditamos que a multi/ interculturalidade é essencial não só para a aprendizagem de vocabulário e regras de uso da língua, mas também para a construção do respeito e da convivência entre os diferentes.

Palavras-chave: Português como segunda língua. Cultura. Multiculturalidade. Interculturalidade. Pré PEC-G.

\section{Introdução}

o ano de 2020, o Projeto MoVe agregou mais um público em suas turmas.
Trata-se de estudantes participantes do PEC-G (Programa de Estudantes-Convênio de Graduações). O PEC-G é um programa que existe desde 1965, administrado pelo Ministério das Relações Exteriores (MRE) e pelo Ministério da Educação (MEC), em parceria com Instituições de Ensino Superior públicas e privadas em todo o país (MRE, 2020). O programa "oferece a estudantes de países em desenvolvimento com os quais o Brasil mantém acordo educacional, cultural ou científico-tecnológico a oportunidade de realizar seus estudos em Instituições de Ensino Superior (IES) brasileiras" (MRE, 2020).

Um dos pré-requisitos para esses estudantes ingressarem no ensino superior no Brasil é a apresentação do Certificado de Proficiência em Língua Portuguesa para Estrangeiros (Celpe-Bras). Para se preparar para o exame, os participantes do PEC-G podem permanecer no Brasil por um ano antes do início do curso superior pretendido, realizando curso preparatório de língua portuguesa em uma IES credenciada. Esse curso é conhecido como Pré-PEC-G.

Em 2020, o IFG recebeu 26 estudantes de Pré-PEC-G, que foram divididos em duas turmas. Neste artigo, focalizaremos as experiências vivenciadas em uma turma de 12 estudantes com diferentes níveis de português, provenientes de oito países da África e América Central e falantes de sete idiomas. Devido à pandemia de Covid-19, as aulas se realizam de forma remota na modalidade síncrona, via plataforma de webconferência Google Meet, e de maneira assíncrona pela plataforma Google Classroom. A metodologia adotada segue os preceitos da abordagem comunicativa crítica e de metodologias ativas de ensino-aprendizagem, ao mesmo tempo que tenta colaborar para a integração dos alunos à comunidade e cultura brasileira e goiana. 
Inicialmente, discutimos brevemente as significações de língua e cultura para falarmos sobre a relação existente entre elas e sua importância nas aulas de português como segunda língua (PL2). Em seguida, passamos ao relato de algumas experiências de trocas multi/interculturais nas aulas. Trazemos também algumas reflexões nossas sobre essas trocas e nossas percepções acerca do processo de ensino-aprendizagem dos alunos estrangeiros.

\section{As relações entre língua e cultura no ensino-aprendizagem de PL2}

Segundo Pereira (2015), há tantas definições para o termo cultura quanto há sociedades e grupos no mundo. Para a autora, a cultura não se resume aos rituais, crenças, costumes ou produtos de um determinado grupo social, mas engloba tudo isso e constitui a trama de nossas vidas. Sapir (1980) tratou da relação entre língua e cultura e concluiu que a língua pode ser considerada como aquilo que dá forma aos pensamentos e sentimentos humanos. Câmara Jr. (1972, p. 54), inspirado em Sapir, afirma que "a língua não tem finalidade em si mesma. A sua função é expressar a cultura para permitir a comunicação social". Assim, para esse autor (1972, p. 58), tudo o que utiliza as faculdades humanas é cultura e a língua é, por sua vez, "um modelo magnífico de estruturação cultural".

Entretanto, para Vygotsky (1991, 1998), a relação entre língua e cultura não é simplesmente de criação e expressão. A língua não apenas expressa a cultura, mas também a cria e vice-versa, pois o ser humano:

Age sobre o meio, transformando-o, mas é, igualmente, transformado no processo, bem como a linguagem e a sociedade. Se a linguagem é manipulada pelo homem, como instrumento psicológico de ação sobre o meio, ela é, da mesma forma, o elemento que promove o desenvolvimento humano e o acesso a novos paradigmas de ação. Assim como a linguagem influencia o homem, ela também é influenciada por ele. Não há relação unilateral, mas, sim, interação e troca. (PEREIRA, 2015, p. 64).

Estabelecida a relação entre língua e cultura, devemos perceber em qual contexto o aluno de L2 se localiza, conhecendo-o e respeitando-o como sujeito sócio-histórico. Isso implica compreender fatores importantes sobre sua cultura, experiência e práticas sociais. Aprender uma nova língua não é uma tarefa simples. E:

[e]ssas dificuldades parecem aumentar principalmente nas situações em que o educador apresenta aos alunos temas muito específicos da cultura estrangeira, pois neste momento não só novas palavras são introduzidas aos alunos, mas também um novo contexto cultural que apresenta diferentes costumes, crenças, hábitos, estrutura social, dentre outros inúmeros aspectos. (LELLES; SILVA; FREITAS, 2014, p. 100). 
A partir dessa compreensão, é importante que os professores de L2 trabalhem temáticas que aproximem as culturas dos estudantes e da língua alvo, pois "ao entrar em contato com uma cultura estrangeira, a interação entre esta e a própria cultura leva uma redefinição da identidade materna e da sua própria identidade" (LELLES; SILVA; FREITAS, 2014, p. 100). À medida que a comunicação se estabelece e ocorrem as trocas linguísticas e culturais, os compartilhamentos de práticas e pensamentos tornam-se vivências e/ou experiências. Oportunizar que os aprendizes façam trocas culturais em sala de aula é mediar que o aluno conheça o outro e se deixe conhecer.

Ao refletir sobre o papel que o ensino de L2 possui, é importante enfatizar os aspectos culturais em sala de aula com o objetivo de ajudar os aprendizes a se posicionarem no mundo, pois "para compreendermos uma língua estrangeira também se torna necessário compreendermos o mundo que ela expressa" (LELLES; SILVA; FREITAS, 2014, p. 102) e vice-versa. Dessa forma, a sala de aula passa a ser um local onde se promove a aprendizagem de língua e se propõem discussões que levem alunos e professores a analisar fatos e ideias. Concordamos com as autoras ao afirmarem que:

\begin{abstract}
Ensinar uma segunda língua não significa apenas expor aos alunos estruturas gramaticais e palavras e pedir que estas sejam memorizadas (...).

Tão importante quanto ensinar a tradução de uma palavra ou de uma expressão para o aluno, é ensinar como essa palavra ou expressão é usada dentro dos diversos contextos daquela linguagem. Para isso, é necessário que consideremos a sala de aula como um espaço sócio- interativo, onde cada aluno é sujeito ativo, criativo e capaz de produzir sentido e significados para suas ações verbais e não verbais, e cabe ao professor saber promover essa construção. (LELLES; SILVA; FREITAS, 2014, p. 103).
\end{abstract}

Quando se trata do ensino de português como L2 para turmas heterogêneas e de diversas origens, como é o caso em análise neste artigo, um dos principais pontos que devem ser levados em conta é o multiculturalismo. Assim como o conceito de cultura e outros elementos relacionados à sociedade, multiculturalismo não tem uma definição única e fechada. Por ser um conceito baseado na construção social, sofre mudanças de acordo com o tempo, com a sociedade e com as ideologias que a cercam. Em termos gerais, multiculturalismo pode ser definido como "a constatação de um fenômeno que envolve a convivência e a coexistência de diversas culturas num mesmo território e num mesmo tempo histórico" (ANDRADE, 2009, p. 17).

O Brasil é considerado um país multicultural, pois há indivíduos das mais diversas formações culturais convivendo em um mesmo espaço e tempo histórico. E a turma de Pré-PEC-G que apresentamos neste artigo também pode ser considerada como multicultural, pois havia pessoas de diferentes lugares (tanto geográficos quanto sociais) e diferentes bagagens culturais, além dos constantes contatos com a cultura brasileira. 
A perspectiva multicultural tem como objetivo trazer maior aproximação e respeito cultural, independentemente das diferenças que possam existir entre tais culturas. No que se refere ao contexto de PL2, o que se busca é um ensino-aprendizagem baseado no respeito às diferenças culturais e sociais antes, durante e depois das aulas. Essas diferenças encontradas dentro das salas de aula e que coexistem entre si é o que chamamos de multiculturalismo interativo ou, como é comumente conhecido, interculturalidade. Trata-se da "promoção deliberada da inter-relação entre diferentes grupos culturais presentes em uma sociedade" (CANDAU, 2008, p. 22). Levando-se em consideração que todos os indivíduos têm formações sociais, ideológicas e culturais distintas e, no caso da turma em discussão neste artigo, são oriundos de diversos países e grupos étnicos, as professoras buscaram se atentar e se preparar para abordar aspectos culturais não apenas do Brasil e da língua portuguesa, mas também das culturas dos estudantes.

\section{Algumas experiências de trocas culturais no ensino de PL2}

Durante a experiência de ministrar aulas ao grupo de 12 alunos, cada qual de um país distinto, e levando em consideração a importância de fazer conexões/interações com os alunos do Pré-PEC-G que estão aprendendo a língua portuguesa brasileira, foi elaborado um plano de aula envolvendo os temas: lendas do folclore brasileiro, animais e ditados populares. A aula tinha por objetivo fazer com que os alunos compreendessem e tivessem contato, mesmo que somente por vídeos, com algumas das manifestações culturais brasileiras. Dessas tradições, escolhemos falar sobre as lendas folclóricas e os ditados populares. Como as lendas folclóricas brasileiras são representadas por muitos animais (mula sem cabeça, boto cor-de-rosa, bumba meu boi), resolvemos ampliar o vocabulário dos alunos e trazer nomes e imagens de animais em geral.

Na aula, além de nós, professoras, apresentarmos aspectos da cultura brasileira, também foram feitas perguntas norteadoras, a fim de que os alunos pudessem compartilhar um pouco dos elementos culturais que envolvem seus países e cidades natais, incentivando assim trocas culturais naturais e produtivas que auxiliam no processo de ensino-aprendizagem. Com essas perguntas e o incentivo para que os alunos dividissem conosco suas experiências, tornamos o ambiente da sala de aula confortável e propício para que se sentissem à vontade para comentar sobre algumas lendas que são comuns em seus países, mencionar o que acharam de interessante nas festas populares brasileiras e a quais gostariam de ir. Essas perguntas são de extrema importância em todo o processo de aprendizagem, pois instigam os aprendizes a se conectarem à cultura brasileira e, por consequência, à língua portuguesa, colaborando, dessa forma, para o aumento do vocabulário e das competências comunicativas que a língua exige. 
Para iniciar a aula, escolhemos um vídeo de animação que contava algumas lendas do folclore brasileiro para assim facilitar o entendimento dos estudantes acerca do assunto e culminar em questões e comentários. Alguns alunos ficaram perplexos com a lenda da mula sem cabeça e riram da ideia de uma mulher que, por namorar um padre, se transformou em um animal que tinha fogo no lugar da cabeça. A perplexidade dos estudantes nos levou a perceber interessantes dados culturais: seja pelo padre namorar uma moça, o que não é aceitável pela Igreja Católica; pela mulher se transformar em um animal como punição; ou até mesmo porque nas culturas dos estudantes talvez não existem representações assim.

Após o vídeo, eles puderam relembrar algumas lendas existentes em seus países ou cidades natais e logo percebemos o quanto a cultura está ligada à língua, sendo indissociáveis. Por meio da língua, essas histórias, parte indispensável da cultura de um grupo social, são contadas e passadas de geração em geração. Muitas palavras das lendas eram intraduzíveis para o português e os alunos tiveram que recorrer a estratégias para representar os conceitos, como imagens, explicações, etc. Um exemplo vivenciado nessa aula foi quando um aluno contou a lenda de Rose Mary, famosa em seu país (Jamaica). A história se passa em uma casa grande, na época da escravidão, e foi interessante observar de que maneira o aluno explicou a lenda e como ele buscou transmiti-la de maneira que todos da sala, independentemente do país de origem, compreendessem a história contada por ele.

A seguir, muitos alunos tiveram espaço para falar sobre festas populares que ocorrem em seus locais de origem, e vários citaram as festas de Independência, pois a aula ocorreu próximo ao feriado da independência do Brasil, o que foi mencionado pelas professoras. Eles expuseram informações detalhadas sobre essas festas, como as comidas que costumam ser servidas, quais tipos de música e dança ocorrem durante essas festividades e qual a importância dessa festa para os seus países. Percebemos um grande senso de amor à pátria e de respeito e admiração à cultura de cada um, um exemplo claro do multiculturalismo interativo: as culturas coexistem em um mesmo espaço, mas não se anulam. Eles conheceram e inclusive admiraram muitas das nossas festas populares, assim como amam e buscaram trazer para a sala de aula um pouco da cultura de seus países para que conhecêssemos também.

Apresentamos festas típicas do Brasil, tais como: Festa Junina, Festival de Parintins, Carnaval e Pecuária de Goiânia. Demonstramos, a partir de vídeos, trechos e características das festas trabalhadas, e os alunos buscaram nas festas apresentadas proximidades com as festas de seu próprio país. Esse fato nos despertou a percepção exatamente do que Lelles, Silva e Freitas (2014, p. 102) afirmam:

A adaptação a uma nova cultura é um processo complexo que passa por várias etapas e que modifica tanto a visão que o indivíduo tem da cultura do seu país de origem quanto da nação estrangeira. Mas no estágio inicial da adaptação, é a cultura do país de origem que vai ser a principal guia do modo de ser do apren- 
diz. Quando um indivíduo aprende uma língua estrangeira também ocorre um processo parecido de identificação e desconstrução de identidades. A segunda cultura, neste estágio primário da aprendizagem, é um novo mundo que se apresenta para ele.

Para finalizar a aula, trouxemos ditados populares brasileiros. Inicialmente, expusemos alguns ditados e explicamos os prováveis significados. Logo em seguida, fizemos um jogo de adivinhações no qual projetamos os ditados populares e, pelo contexto, os alunos teriam que descobrir o que a frase significava. A figura a seguir ilustra essa atividade:

Figura 1. Atividade de adivinhação

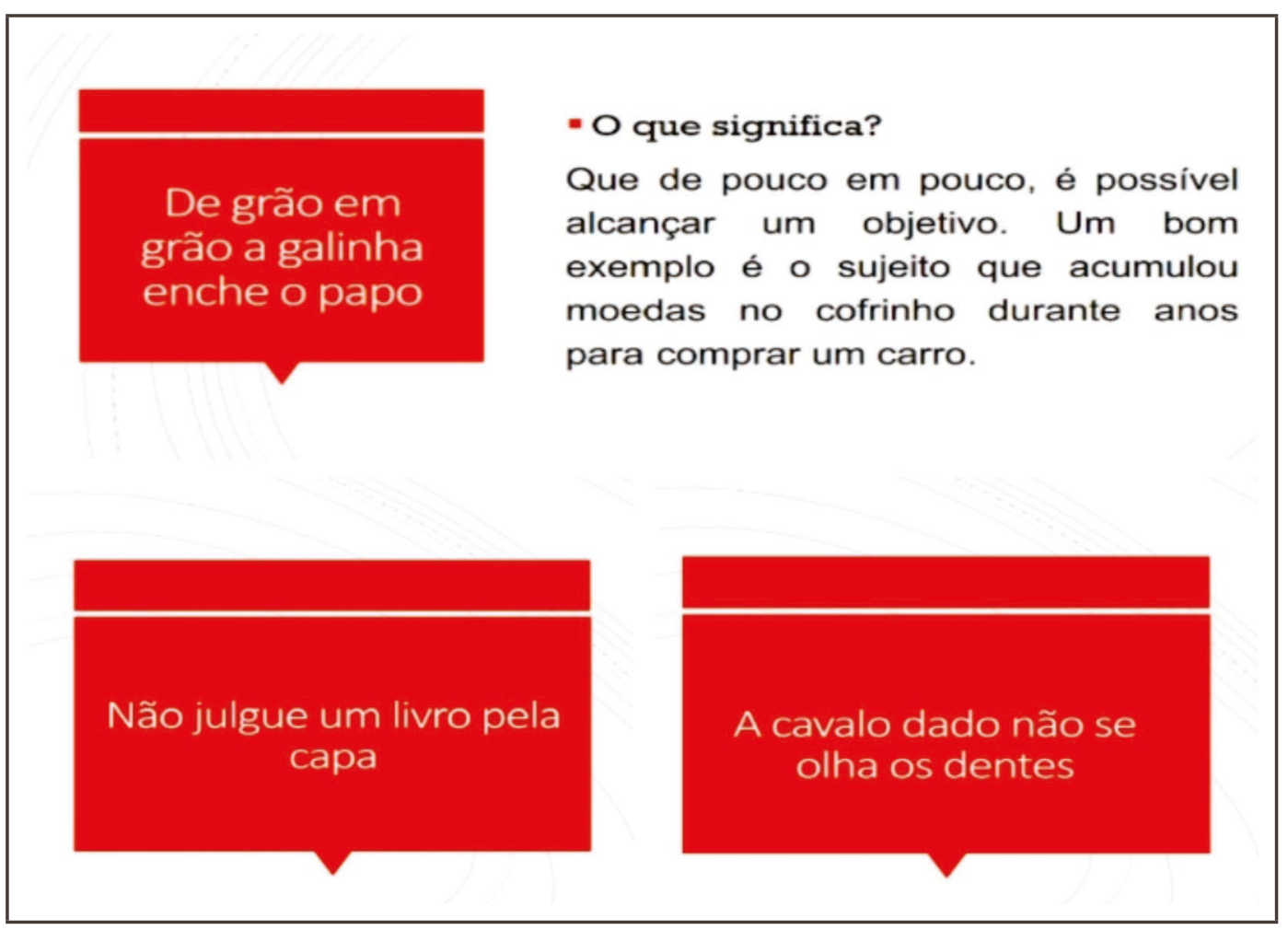

Fonte: Acervo das professoras.

Para nossa surpresa, os alunos mostraram-se bastante empolgados e participativos. Todos falaram sobre o que entendiam dos ditados e muitos acertaram e iam além, conseguiam comparar com ditados do seu país. A aula certamente foi uma grande troca de aprendizados e mostrou-se multicultural. Houve o respeito à cultura do outro e discussões produtivas que renderam acréscimos ao vocabulário e ao repertório cultural dos alunos e das professoras.

Para encerrar, foi proposta como tarefa de casa que cada estudante escolhesse uma manifestação cultural do seu país e escrevesse um texto explicando-nos como é 
tal festa, em que mês ocorre, quais as principais características e trouxessem imagens que representassem a festa da qual eles falaram. Nas figuras a seguir podemos observar a tarefa de um aluno:

Figura 2. Texto da tarefa "Festa popular"

O Dia da Independência da Jamaica é um feriado nacional celebrado em comemoração à independência da Jamaica do Reino Unido em 6 de agosto de 1962. É comemorado anualmente em 6 de agosto, mas as várias atividades e eventos culturais acontecem na semana antes do dia da independência. O evento geral é chamado de Festival da Jamaica e apresenta artistas literários e performáticos do pais, bem como exposições agricolas e desfiles em todo o país. Alguns dos eventos mais populares incluem a competição de música e o show agrícola de Denbigh. Na competição de música, os competidores escrevem e executam suas próprias músicas, que devem ter letras sobre a Jamaica ou ser jamaicano, e o público pode votar na música que eles acreditam que deveria ser o vencedor.

Fonte: Google Classroom.

Figuras 3 e 4. Imagens da tarefa "Festa popular"

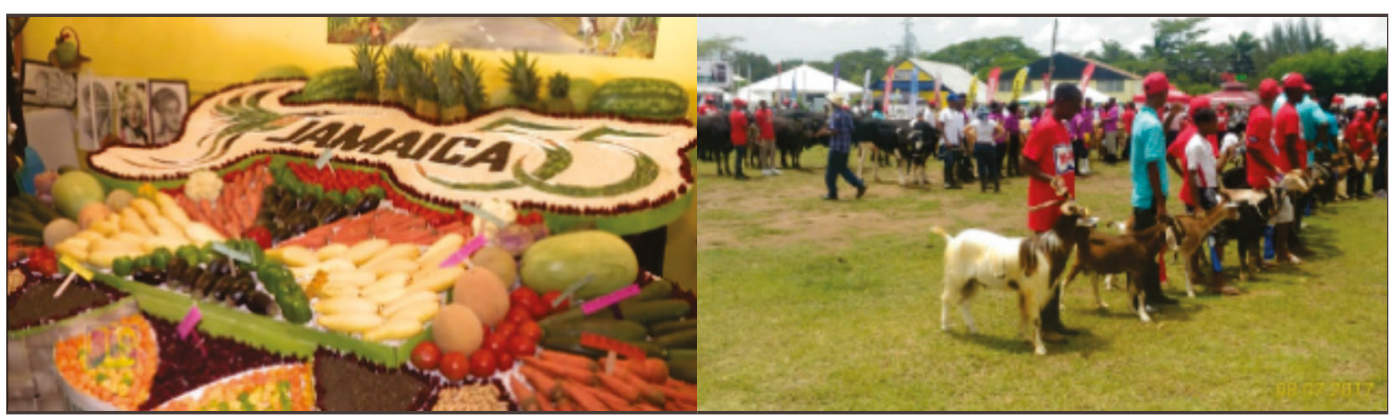

Fonte: Google Classroom.

Figura 5. Imagens da tarefa "Festa popular"

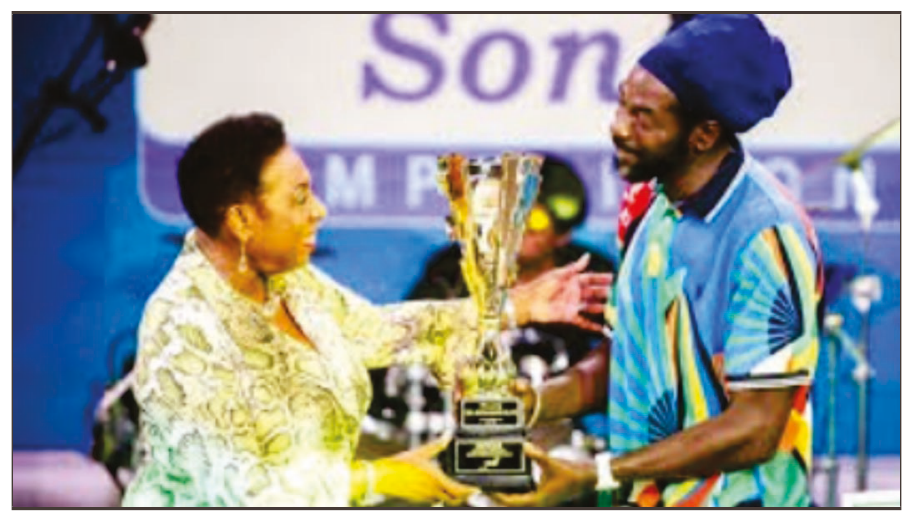

Fonte: Google Classroom.

Outra aula que também proporcionou muitas trocas culturais foi quando tratamos sobre alimentação. Lima, Ferreira Neto e Farias (2015, p. 508) afirmam que "[m] uito além de uma atitude biológica, a alimentação assume também um comporta- 
mento cultural". Dessa forma, os alimentos funcionam como combustível para nosso corpo e também nutrem nossa identidade cultural. A partir da ideia de alimentação como algo que perpassa todas as culturas, escolhemos essa aula para ilustrar as diversas trocas interculturais que ocorrem em uma sala de aula multicultural.

Partimos da temática de "Respeito às diferenças", cujo objetivo era discutir sobre os diferentes modos de alimentação. Introduzimos o vocabulário sobre alimentos naturais e processados com o intuito de engajar os alunos, mediando o conteúdo a partir de imagens de alimentos populares e trazendo uma discussão sobre eles. A finalidade desse momento introdutório foi de ativar no aluno um vocabulário contextualizado viabilizando a comunicação entre eles.

Após a familiarização com o vocabulário de alimentos, os alunos foram conduzidos a relatar sobre quais alimentos mais gostavam e detestavam. Associamos, também, perguntas sobre suas refeições de dias anteriores, para que usassem verbos no passado. Essa atividade comunicativa com verbos no passado tinha a finalidade de contextualizar a ideia de lembrança, pois queríamos tratar mais a fundo o tema "Memória alimentar". Iniciamos o diálogo falando sobre comidas que nos traziam lembranças afetivas e conduzimos questionando os alunos sobre quais comidas de seus países eles sentiam saudades e quais recordações tinham sobre elas. Assim, conseguimos fazer trocas culturais sobre alimentos que nos recordavam de momentos afetuosos. Como podemos ver no trecho abaixo, retirado da atividade oral "Memória e Alimentação", eles conseguiram fazer essa relação cultural com os alimentos:

\footnotetext{
[Trecho de atividade oral]

Estudante: Eu gosto muita das lentilhas e a minha mãe sabe disso. Sempre que era meu aniversário ela fazia pra mim e antes de vir para aqui ela fez para eu comer pela últimas vez. Sempre que eu como lentilhas ela é quem vem na minha cabeça. Infelizmente ninguém o faz como ela, mas supero.
}

A comida é uma das temáticas de maior importância quando falamos sobre culturas, pois os alimentos carregam histórias que constituem a identidade social de uma população, como afirma Santos (2015, p. 12, grifos nossos):

As cozinhas locais, regionais, nacionais e internacionais são produtos da miscigenação cultural, fazendo com que as culinárias revelem vestígios das trocas culturais. Hoje, os estudos sobre a comida e a alimentação invadem as Ciências Humanas a partir da premissa de que a formação do gosto alimentar não se dá, exclusivamente, pelo seu aspecto nutricional, biológico. $\mathbf{O}$ alimento constitui uma categoria histórica, pois os padrões de permanência e mudanças dos hábitos e práticas alimentares têm referências na própria dinâmica social. Os alimentos não são somente alimentos. Alimentar-se é um ato nutricional, comer é um ato social, pois constitui atitudes ligadas aos usos, costumes, protocolos, condutas e situações. Nenhum alimento que entra em nossas bocas é neutro. 
Ao falar sobre as comidas típicas de seus países que evocavam memórias afetivas, muitos alunos tiveram dificuldade com palavras que não existem em português e recorreram, novamente, a estratégias como uso de imagens. Segundo Lelles, Silva e Freitas (2014, p. 103):

[é] importante termos em mente que muitos dos nossos hábitos e costumes podem ser totalmente desconhecidos e diferentes para indivíduos pertencentes a outras culturas. Consequentemente, não podemos esperar que a linguagem dos mesmos possua palavras que representem estes hábitos e costumes que são inexistentes para eles.

Durante a atividade, um aluno procurou no Google uma imagem do prato que estava tentando descrever e projetou (compartilhou tela) no Google Meet para que todos pudessem conhecer, como podemos observar na Figura 6, a seguir:

Figura 6. Bambucha, prato típico de Guiné Equatorial

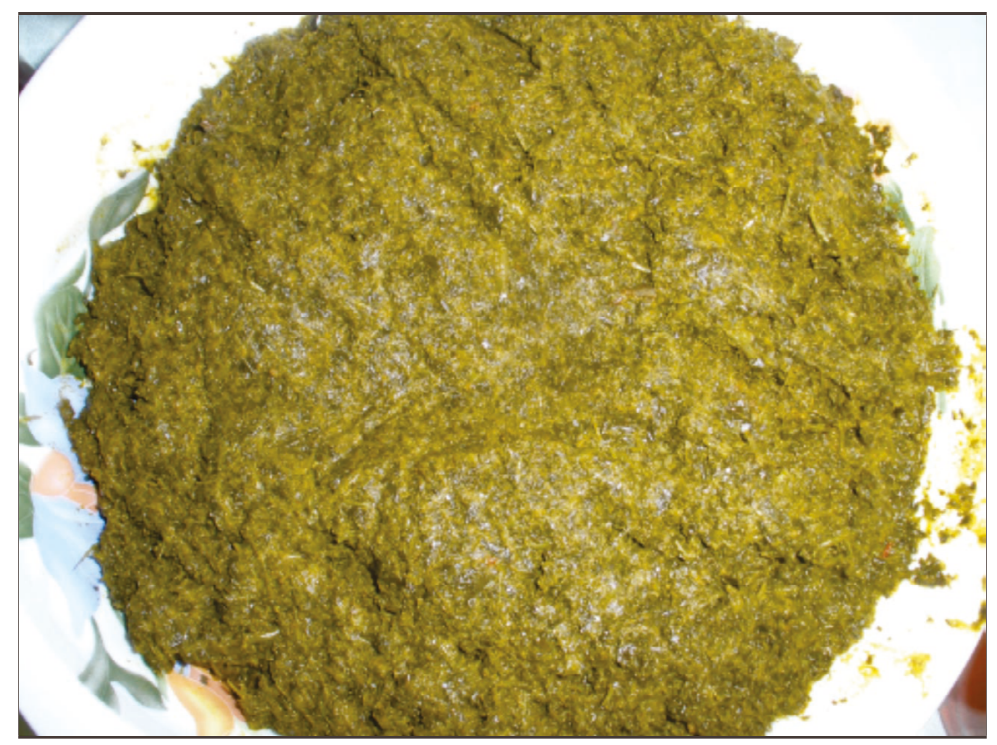

Fonte: Google Meet.

Segundo o estudante, "é uma comida que comemos na casa de avós" e trata-se de um prato específico de sua etnia (fang ou mendja). Outros alunos de outras nacionalidades fizeram perguntas sobre os ingredientes que compõem o prato e teceram comentários sobre comidas parecidas em seus países. Um aluno ganês reconheceu um prato parecido em Gana e teceu comparações ressaltando as semelhanças e diferenças e explicando como acontecia a situação social de reunião da família e manuseio do alimento. A menção a ser um prato típico de uma etnia específica fez com que uma aluna da Jamaica do Gabão também mencionasse um prato típico de seu grupo social, ao que outro colega jamaicano ressaltou que se tratava de um prato exclusivo 
da etnia dela e que ele, por ser de outra região e outra etnia, não tinha acesso àquele alimento. Destacamos essa observação do aluno jamaicano gabonês, pois é importante reconhecermos que, embora estejamos tratando de culturas num sentido amplo e geral, existem muitas culturas dentro de um mesmo país ou grupo e que o multiculturalismo também está relacionado a esse reconhecimento e respeito.

Diferentes trocas ocorreram durante a aula e gostaríamos de destacar alguns exemplos da atividade escrita "Memória e Alimentação", em que os alunos redigiram um texto a partir das reflexões feitas na aula. Como podemos ver na Figura 7, o aluno apresentou alguns alimentos que costumava consumir em seu país e relacionou-os a hábitos e costumes, como determinadas comidas típicas dos finais de semana, por exemplo.

Figura 7. Trecho da atividade escrita "Memória e alimentação"

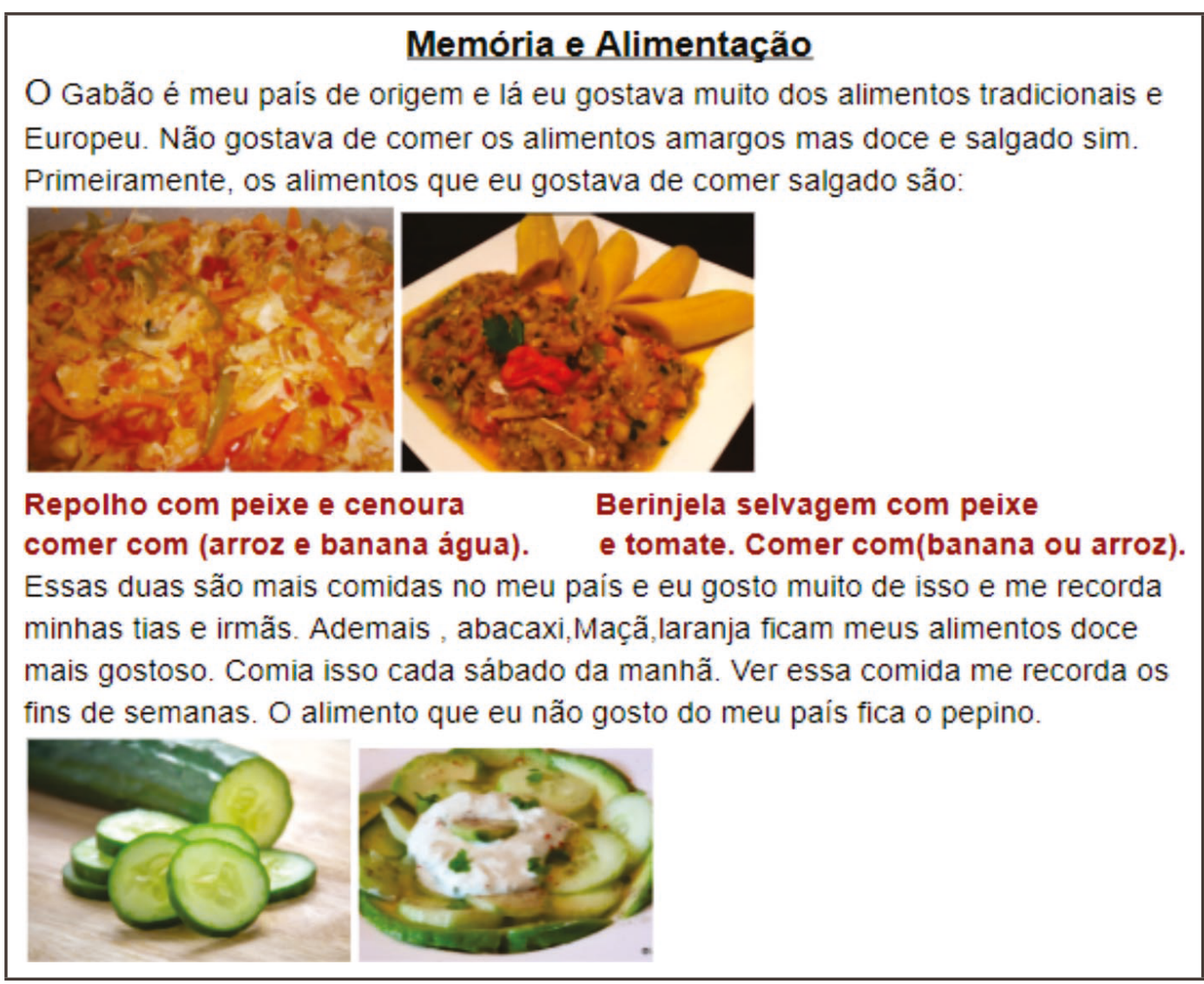

Fonte: Google Classroom.

Além de apresentar os alimentos conhecidos, o estudante foi além e tentou aproximar os alimentos presentes em sua cultura com pratos característicos do Brasil, e ainda fez uma reflexão acerca dos diferentes alimentos que existem, como podemos ver na figura a seguir: 
Figura 8. Trecho da atividade escrita "Memória e Alimentação"

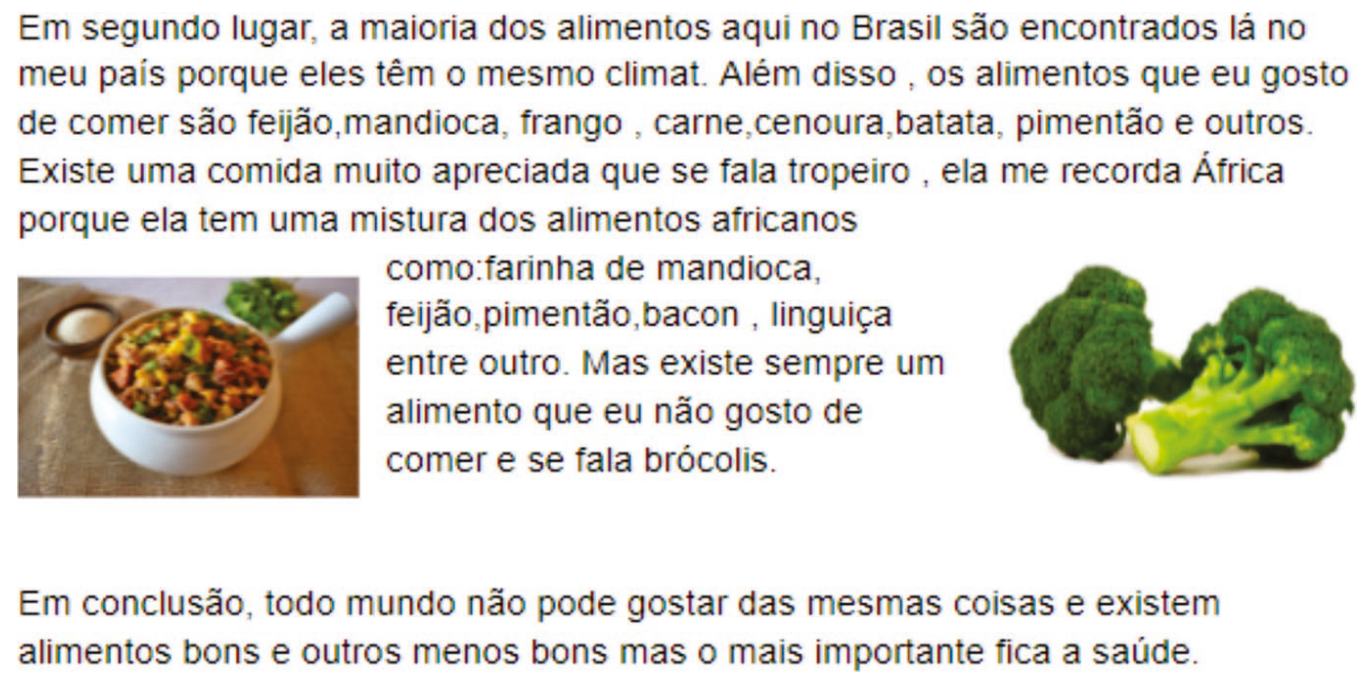

Fonte: Google Classroom.

Diferentemente do relato acima, outro aluno optou na tarefa por nos apresentar marcas interculturais que nos diferenciam. Apesar de possuir domínio linguístico o suficiente para fazer comparações com os alimentos presentes em sua cultura, ele preferiu destacar as diferenças alimentares entre o Brasil e seu país.

Figura 9. Atividade escrita "Memória e alimentação"

Aqui no Brasil há muitos tipos de comida, quase as mesmas que temos no meu país, então vou falar dos alimentos que não temos em comum, começando dos alimentos mais simples, gosto muito dos pães daqui eles são bem diferente aos tipos do meu país, gosto muito dos pastéis daqui também, os do meu pais são diferentes, mas ambos são bons, também gosto de feijão com arroz com um pouco de salada que fazem aqui, também gosto da comida que não me lembro do nome, a gente vende ela nas estradas, são feitas com pasta, eles colocam salsicha dentro algumas vezes carne isso é bem gostoso, costumam custar uns 4 á 5 reais, gosto de quase todas as frutas, lá no meu país não temos muitas variedades de frutas, eu pessoalmente gosto das frutas porque contêm muitas vitaminas, gosto de Guaraná, os sucos naturais também, também algumas cervejas. Os peixes são bons, mas eu pessoalmente não como muito inclusive lá no meu país não comia muito, a carne é a mesma que a de meu país mas tem um sabor diferente, gosto mais dos de meu país talvez porque estou acostumado a eles, mas com o tempo espero estar acostumado e desfrutar melhor delas melhor.

Lá no meu país temos algumas coisas que não gosto, a gente come, mas eu não, mas a gente fala que contêm muita vitamina.

Fonte: Google Classroom. 
Ao tentar traçar paralelos e diferenças entre os alimentos comuns no Brasil e nos seus países, os estudantes fazem o movimento de ressignificação identitária discutido por Lelles, Silva e Freitas (2014). Podemos perceber que a língua-cultura 1 é a base de ancoragem para a percepção de novas palavras, novas formas de se expressar e de ver o mundo. As trocas culturais ocorridas nessa aula foram muito ricas e consideramos que foi produtiva numa perspectiva multi/intercultural e também comunicativa.

\section{Considerações finais}

Além de aprimorar nossas habilidades técnicas e metodológicas, as vivências nas aulas de PL2 na turma de Pré-PEC-G possibilitaram um grande crescimento pessoal e profissional para todas nós. A partir das experiências vividas nessa turma, pudemos aprender muito com os estudantes, conhecer sobre países e povos dos quais tínhamos pouca ou nenhuma informação, desconstruir estereótipos e preconceitos, construir e exercitar as habilidades de diálogo ativo, respeito, curiosidade, tolerância e fraternidade.

Ao longo deste artigo, discutimos como as trocas culturais são importantes no processo de aprendizagem dos alunos. Mas acreditamos também que essas relações multi/interculturais são fundamentais na formação de professores de PL2. Podemos dizer que a experiência de ensinar português foi também uma oportunidade de aprender muitas coisas que, provavelmente, não aprenderíamos em outras circunstâncias. Pudemos, inclusive, refletir muito sobre nossa própria língua materna ao ensiná-la para estrangeiros. O processo de ressignificação da identidade, que abordamos neste trabalho, não aconteceu apenas com os alunos, mas também conosco, pois refletimos sobre quem somos, o que fazemos e o que podemos fazer para construir um mundo onde todas as culturas e línguas sejam respeitadas.

\section{Referências}

ANDRADE, M. A diferença que desafia a escola: apontamentos iniciais sobre a prática pedagógica e a perspectiva intercultural. Rio de Janeiro: Quartet, 2009.

CÂMARA JR., J. M. Língua e cultura. In: Carlos Eduardo Falcão Uchôa (sel. e intr.). Dispersos de J. Mattoso Câmara Jr. Rio de Janeiro: Fundação Getúlio Vargas, 1972.

CANDAU, V. Multiculturalismo e educação: desafios para a prática pedagógica. In: MOREIRA, A.; CANDAU, V. (orgs.). Multiculturalismo: diferenças culturais e práticas pedagógicas. 2. ed. Petrópolis: Vozes, 2008. 
LELLES, K. C.; SILVA, H. M. de L.; FREITAS, M. S. de. Considerações sobre a compreensão linguística e cultural no ensino e aprendizagem de línguas estrangeiras. Letras Escreve, v. 4, n. 1, p. 99-106, 2014. Disponível em: https://periodicos.unifap.br/index.php.letras/article/view/1675. Acesso em: 10 set. 2020.

LIMA, R. de S.; FERREIRA NETO, J. A.; FARIAS, R. de C. P. Alimentação, comida e cultura: o exercício da comensalidade. Demetra, v. 10, n. 3, p. 507-522, 2015. Disponível em: https://www.e-publicacoes.uerj.br/index.php/demetra/article/viewFile/16072/13748. Acesso em: 13 out. 2020.

MRE. Ministério das Relações Exteriores. Programa de Estudantes-Convênio de Graduação - PEC-G. Apresentação. 2020. Disponível em: http://www.dce.mre.gov.br/ PEC/PECG.php. Acesso em: 13 out. 2020.

PEREIRA, P. G. As relações entre língua, cultura, música e o processo de ensino-aprendizagem de língua estrangeira. Revista Estudos Anglo Americanos, n. 43, p. 62-83, 2015. Disponível em: https://reaa.ufsc.br/index.php/reaa/article/view/1320. Acesso em: 13 out. 2020.

SANTOS, C. R. A. dos. A alimentação e seu lugar na história: os tempos da memória gustativa. Revista da Academia Paranaense de Letras, n. 51, p.165-188, 2005. Disponível em: http://www.historiadaalimentacao.ufpr.br/artigos/artigo001.htm. Acesso em: 13 out. 2020.

SAPIR, E. The status of linguistics as a science. In: SMOLINSKI, F. (ed.). Landmarks of American language and linguistics. Washington, D.C.: Bureau of Educational and Cultural Affairs, 1980. p. 9-13.

VYGOTSKY, L. S. A formação social da mente. São Paulo: Martins Fontes, 1998.

VYGOTSKY, L. S. Pensamento e linguagem. 3. ed. São Paulo: Martins Fontes, 1991. 
Resumo: Este capítulo traz um recorte da atuação de dois alunos do curso de Licenciatura em Letras: Língua Portuguesa do IFG, câmpus Goiânia, Isaque Lima da Silva e Kamilla Christina Alves, no Projeto de Ensino-extensão 'Movimentos migratórios em V: ensino-aprendizagem de português para falantes de outras línguas', ministrando aulas de língua portuguesa como língua de acolhimento (PLAc) para a turma Acolher A1, composta por cinco migrantes haitianos, residentes em Goiânia, quatro deles falantes zero de português e uma falante inicial dessa língua. O processo ensino-aprendizagem segue a perspectiva da teoria sociocultural para o ensino de línguas (VYGOTSKY, 1998) e tem como referencial de conteúdo o livro Pode Entrar, disponibilizado para uso público pela Acnur-Brasil. Os planos de aula e os materiais didáticos são construídos pelos licenciandos regentes sob a orientação da professora Dra. Suelene Vaz da Silva e armazenados no drive do Google Classroom. As aulas acontecem às segundas e sextas-feiras, das $19 \mathrm{~h}$ às 20h30, no ambiente Google Meet e possuem como língua de ancoragem o crioulo, realizado por meio da mediação de um haitiano - Shelton Mathieu - aluno do ensino superior no IFG, câmpus Goiânia. O aplicativo WhatsApp é outra ferramenta midiática utilizada como recurso de aprendizagem por meio de interações entre regentes e alunos e de postagem de tarefas orais e escritas para a prática da língua portuguesa, além de se constituir como um canal de comunicação direta com os alunos, o que estreita as relações interpessoais entre regentes e alunos por meio da construção de laços afetivos. Para os regentes, o fazer docente tem sido construído na ação de ministrar as aulas, tendo o aluno como centro do processo ensino-aprendizagem e a ressiginificação das abordagens, dos conteúdos e do material didático, como as premissas básicas para a integração do aluno como sujeito ativo do seu próprio processo de aprendizagem.

Palavras-chave: Formação docente na ação. Ensino-aprendizagem de PLAc. Haitianos. Tecnologias digitais.

\section{Iniciando a jornada}

Dor decorrência da pandemia de Covid-19 e da exigência de distanciamento entre as pessoas para evitar a propagação da doença, as aulas presenciais do Instituto Federal de Educação, Ciência e Tecnologia de Goiás (IFG) foram suspensas e, entre elas, as aulas do projeto de extensão "Acolher, ensinar e aprender: português para imigrantes em situação de vulnerabilidade", porém, o acolhimento aos migrantes não.

Assim, as plataformas digitais adotadas pela instituição como ambientes para aulas na modalidade remota também foram compreendidas como ferramentas tecnológicas que poderiam ser aliadas para a promoção do ensino de Português como Língua de Acolhimento (PLAC). Para tal, a proposição face a face adotada para as aulas foi ressignificada para uma nova proposta de ação via contextos virtuais, intitulada 'Movimentos migratórios em $\mathrm{V}$ : ensino-aprendizagem de português para falantes de outras línguas - MoVe'.

Como já mencionado no capítulo 1 , o projeto possui dez turmas, das quais este capítulo aborda a experiência de dois alunos do curso de Letras Licenciatura - Língua 
Portuguesa do Instituto Federal de Educação, Ciência e Tecnologia de Goiás (IFG), câmpus Goiânia, Isaque Lima da Silva, atualmente cursando o quinto período, e Kamilla Christina Alves, cursando o oitavo período, professores em formação atuando como licenciandos regentes de cinco alunos haitianos, em uma turma denominada de Acolher A1. Essa nomeação segue o que postula o Quadro Europeu Comum de Referência para Línguas (Common European Framework of Reference for Languages - CEFR) para o nível iniciante de conhecimento de segunda língua ou de língua estrangeira. Contudo, há de se considerar que o nível A1 é o grau de expectativa de os cinco alunos alcançarem após o término do período de aulas, pois o nível deles ao início do período letivo configurava-se como falante zero de português.

O fato de os alunos não falarem português e de os professores não falarem crioulo, língua materna dos haitianos, fez surgir a necessidade da figura de um mediador para exercer o papel de apoio nas interações entre os licenciandos regentes e os haitianos. A mediação foi então realizada por meio do uso do crioulo como língua de ancoragem para a aprendizagem de PLAc pelo haitiano, aluno do IFG de Engenharia Civil, no câmpus Goiânia, Shelton Mathieu, que vive no Brasil há mais de três anos e foi aluno de português na etapa presencial das aulas em 2018, antes de ele ser aprovado no vestibular do IFG. Silva $(2012 ;$ 2015) e Luvizari-Murad (2011) defendem a relevância do uso de uma língua de ancoragem como suporte para a ampliação da comunicação entre os envolvidos no processo ensino-aprendizagem, seja nas interações com o propósito de ensinar-aprender algo, seja para dar e receber instruções, seja para manter o vínculo afetivo entre aprendizes e entre aprendizes e professor.

As aulas síncronas foram acordadas para acontecerem às segundas e sextas-feiras, das 19h às 20h30, no ambiente de webconferência Google Meet. As aulas assíncronas seriam na plataforma Google Classroom, ambiente descartado para a turma Acolher A 1 em razão da dificuldade apresentada por eles para acesso a ferramentas digitais. Esse ambiente foi substituído pelo aplicativo de mensagem WhatsApp criado para comunicação entre os licenciandos regentes e os alunos haitianos, com a presença do mediador Shelton. É importante ressaltar que após cada aula síncrona há um momento de reflexão entre os licenciandos regentes e a professora orientadora responsável pela turma, professora Dra. Suelene Vaz da Silva. Ambos os momentos síncronos são gravados para composição de um banco de dados para estudos futuros.

Os planos de aula e o material didático (slides, imagens, jogos, formulários, links de vídeos, etc.) são armazenados no Google Drive na pasta da turma Acolher A1, compartilhada entre os licenciandos regentes e a orientadora. Bem como também são armazenadas as gravações das aulas, das sessões reflexivas e os momentos de planejamento, pois todas as atividades relacionadas ao projeto são feitas de forma colaborativa, utilizando as ferramentas já citadas como ambiente para os encontros entre os licenciandos regentes. Essa perspectiva segue o que enfatiza Figueiredo (2015, p. 44) ao afirmar que: 
[a] aprendizagem colaborativa é uma abordagem construtivista que se refere, grosso modo, a situações educacionais em que duas ou mais pessoas aprendem ou tentam aprender algo juntas, seja por meio de interações mediadas pelo computador, cuja ênfase recai na construção conjunta do conhecimento dentro e a partir dessas interações.

O planejar, criar o material didático, ministrar as aulas e refletir acerca delas são etapas de um todo colaborativo, em que a construção de cada aula tem por premissa o trabalho em equipe, no qual uma pessoa ensina e aprende com a outra, em um processo contínuo e infinito, como propõe a teoria sociocultural. Vygotsky (1998) afirma que o indivíduo aprende a partir de sua interação com o meio social, com ênfase na interação com outro indivíduo, o par competente, o qual sabe algo que o outro ainda não aprendeu, mas esse outro possui o potencial para a aprendizagem. O par competente medeia a aprendizagem do outro, conduzindo-o de seu nível potencial para o nível real, ou seja, a internalização do conhecimento. É nesse sentido que o trabalho colaborativo entre os licenciandos regentes e entre eles e a orientadora é desenvolvido e estendido para a relação entre os alunos haitianos, o mediador e os regentes.

A base sistemática do conteúdo das aulas sustenta-se no livro didático Pode Entrar, uma obra de realização conjunta do Curso Popular Mafalda, o Alto Comissariado das Nações Unidas para Refugiados (Acnur) e a Cáritas Arquidiocesana de São Paulo (Casp). Na elaboração de cada aula, é priorizada a correlação entre as relações cotidianas e a vivência dos alunos com o conteúdo programático, utilizando materiais didáticos que referenciem as características, preferências e opiniões dos alunos para a ilustração e exemplificação do material didático. A intenção é harmonizar a ação de acolhimento e o respeito à identidade do migrante, trazendo para o contexto de aula as falas, imagens, gostos alimentares, de vestuário, ou seja, elementos da vida deles.

\section{As aulas}

Antes da primeira aula, criamos o grupo no aplicativo do WhatsApp para informarmos aos alunos a data do primeiro encontro. A mensagem de boas-vindas foi feita pela licencianda regente Kamilla, em que ela disse:

[1]

[Primeira mensagem enviada no grupo "MoVe A1" - 08 de julho de 2020] Kamilla: Olá a todos! Sejam bem-vindos ao nosso grupo de WhatsApp do projeto Movimentos Migratórios em V. Alguém nesse grupo FALA português?

Os alunos responderam à mensagem por áudio, contudo em crioulo. O mediador Shelton interveio traduzindo para português o que eles haviam dito, e para o crioulo a nossa mensagem de recepção, bem como o aviso da data da primeira aula, com a explicação sobre o link de acesso. 
Para facilitar esse acesso, gravamos vídeos e postamos no grupo de WhatsApp com o passo a passo ensinando a baixar o aplicativo usado para os encontros semanais e ensinando-os a acessar o link em que as aulas aconteceriam. Utilizamos vídeos instrucionais com o passo a passo do processo de baixar e acessar a sala de aula virtual, primeiramente sem som e depois com uma narração em português compassada, na esperança de que eles entendessem as instruções.

No início do primeiro encontro síncrono, apenas dois alunos entraram na sala virtual. O mediador então fez a seguinte fala:

[2]

[Transcrição de trecho da primeira aula, 8 julho de 2020]

Shelton: Então, o que eu acho... só que, você sabe... eles estão numa fase agora que eles não tinham o costume de fazer, tipo, fazer aula online, usar essa ferramenta né para continuar fazendo, trabalhando, né? pra ensinar a língua portuguesa pra eles. Mas só que antes disso, eles não tinham o conhecimento, né? sobre o uso, né, nesse fato, ferramenta que é o Google Classroom. Eu acho que esse encontro que todos eles não vão participar, aí no próximo encontro eu acho que eu queria seria muito importante, né pra ensinar cada passo, né. que eles que eles tem que usar, né, no momento que a gente vai ter aula, entende? Isso é importante, porque eu conheço eles muito bem, eles têm muita dificuldade nesse assunto, né, aí eu acho que depois disso, né em primeiro momento, depois eles vão ter mais habilidade né, para assistir as outras aulas normais. tá bom. ${ }^{1}$

A fala de Shelton nos levou a retomar as instruções que havíamos passado por vídeo no grupo de WhatsApp, pois nosso planejamento previa o trabalho com apresentação pessoal, isto é, nós nos apresentando para os alunos e os alunos se apresentando uns para os outros e para nós. Percebemos que antes de os conhecer precisávamos retomar o acesso e abordar a ambientação deles com a plataforma Google Meet. Solicitamos ao Shelton que explicasse aos alunos presentes, oralmente, por meio da língua de ancoragem, o crioulo, e também que enviasse mensagem de áudio, via WhatsApp, para os outros alunos, explicando detalhadamente como realizar o acesso à sala. Pedimos ainda que ele enfatizasse que estávamos abertos a retomar as explicações de uso do Google Meet para auxiliá-los no processo de acesso à sala virtual. Essas orientações podem ser conferidas no recorte a seguir da conversa entre os licenciandos regentes e o mediador.

\section{[3]}

[Transcrição de trecho da primeira aula, 8 julho de 2020]

Isaque: então, só pra falar dos que não conseguiram entrar, nós não seremos injustos se precisar voltar a gente volta sem nenhum problema, tá? É porque assim, a gente... é... é... vai aproveitar que já estamos aqui e passar a aula mesmo, ok? Esse primeiro é só uma introdução, que é a parte de apresentação.

\footnotetext{
1 Um relato antes da primeira aula.
} 
Shelton: Eu posso repetir pra eles? Tá bom, obrigado [tradução para o crioulo]. Pode continuar, Isaque.

Isaque: Então, eu me chamo Isaque e a nossa intenção aqui é quebrar as barreiras linguísticas e diminuir os impactos da adaptação de vocês aqui. Nós somos conhecidos por sermos acolhedores e nós iremos apresentar isso, com toda certeza.

Kamilla: Eu me chamo Kamilla, nossa intenção nas aulas de português é auxiliar vocês a darem os primeiros passos linguísticos no nosso país, por meio do acolhimento pretendemos trocar experiências e sabedoria nesse grupo que vão além do ensino de português. O nosso objetivo inclui trocas culturais e afetivas, portanto não tenham vergonha de questionar, se preciso for pode mandar mensagem no WhatsApp que a gente vai auxiliar vocês no que for preciso. ${ }^{2}$

Após as explicações na língua de ancoragem, nós iniciamos a apresentação pessoal e do conteúdo previsto. Notamos que alguns alunos chegaram apreensivos e silenciosos. O mediador conversou com eles, em crioulo, e eles demonstraram sentir-se mais confortáveis com o ambiente virtual e com a nossa presença enquanto professores. A orientadora também fez intervenções pontuais no decorrer da aula, lembrando-nos que deveríamos enfatizar nossos nomes e os nomes deles, já que a câmera não possibilitava vermos uns aos outros na totalidade, mas apenas o rosto e parte do tronco, o que dificultaria a nossa identificação e, ao nomear, nós também estávamos tentando nos colocar mais próximos deles.

Nessa aula, abordamos termos de cumprimento e de apresentação pessoal, tais como, "boa noite", "bom dia", "boa tarde", "meu nome é", "qual seu nome?", "oi", "tudo bem", "tudo bom", "obrigado", "por favor", como podemos observar no trecho a seguir.

[4]

[Transcrição de trecho da primeira aula, 8 de julho de 2020]

Kamilla: Oi, Fritznel, tudo bom?

Fritznel: Oi, tudo bem, Kamilla.

Kamilla: Oi, Widley, tudo bom?

Widley: Oi, Tudo bem.

Kamilla: Meu nome é Kamilla, qual seu nome, Isaque?

Isaque: Olá, kamilla, meu nome é Isaque, qual o seu nome, Widley?

Widley: Meu nome é Widley.

[...]

Kamilla: Qual o seu nome, Fritznel?

Fritznel: Qual nome... Qual meu nome Fritznel. Qual nome, qual seu nome, Kamilla?

Kamilla: Meu nome é Kamilla, qual seu nome, Fritznel?

Fritznel: Meu nome Fritznel, qual nome Kamilla?

Kamilla: Vamos de novo, qual seu nome, Fritznel?

\footnotetext{
2 Um recorte dos momentos iniciais da primeira aula.
} 
Trabalhamos em uma perspectiva mais estruturalista de língua, com bastante repetição e com a explicação do sentido na língua de ancoragem. Ao final, os alunos conseguiram despedir-se utilizando os termos aprendidos "tchau', "obrigado" e "boa noite".

A experiência vivenciada na primeira aula foi fundamental para conhecer os alunos, tirar o nosso nervosismo por altíssima taxa de adrenalina, perceber que é importante evitar extrapolar na fala ou interromper a fala do colega professor ou do aluno, dosar a quantidade de conteúdo para o tempo relógio da aula, enfatizar os nomes dos alunos, compreender a variação do "delay" entre computador e celular, evitar acentuar inadequações de pronúncias, mudando a forma de falar as palavras e aprender que para um não falante de português era fundamental pronunciar novamente as palavras e frases, de forma mais marcada, delicada e respeitosa.

[5]

[Transcrição de áudio de WhatsApp - 8 de julho de 2020]

Isaque: Professora, eu falei no final da transmissão (sessão reflexiva), mas eu queria reforçar com a senhora, estou muito feliz por hoje, foi assim, muito importante para mim. Os primeiros passos de uma pessoa em outro país é muito complicado e estar presente nesse momento é fundamental, assim... (...) então, eu estou no caminho para seguir e eu preciso da senhora, preciso que a senhora me dê um feedback. (...). Agradecer a oportunidade mais uma vez (...) estou muito animado, professora. [...] e ter a senhora hoje, puxando, Isaque vamos lá e tal... Nossa, professora, eu só tenho agradecer [...] a senhora está mudando minha vida [...].

Nas aulas seguintes, além de reforçar os cumprimentos, introduzimos uma apresentação de slides em que trouxemos sentenças com o bairro e a cidade, onde os alunos moram, e algumas informações pessoais deles, por exemplo: "Meu nome é Charly. Eu moro em Goiânia, no Jardim Guanabara. Eu tenho 22 anos. Eu sou haitiano".

Trabalhamos os meses do ano, alguns números cardinais que seriam necessários para identificar a idade e a data de nascimento dos alunos. Utilizamos sentenças simples, mas que já traziam a perspectiva de uma interação mais significativa, embora ainda na perspectiva de repetição de uma informação pronta, como nos apresenta o excerto 6.

[6]

[Transcrição de trecho da quinta aula, 20 de julho de 2020]

Isaque: Meu nome é Fritznel.

Fritznel: Meu nome é Fritznel.

Isaque: Eu moro em Goiânia.

Fritznel: Eu molo Goiânia.

Isaque: No Jardim Guanabara.

Fritznel: No Jardim Guanabanha. 
Isaque: Eu tenho 33 anos.

Fritznel: Eu tenho (...) tlinta e tlês anios.

Isaque: Eu sou haitiano.

Fritznel: Eu sou haitiano.

Dando sequência ao conteúdo, abordamos o ensino do alfabeto e, para esse tópico, decidimos sair do tradicional, como apresentado no livro por meio da sequenciação das letras de A Z, e trabalharmos com soletração a partir de nomes dos próprios alunos, como ' $\mathrm{C}$ de Charly', 'W de Widley' e 'F de Fritznel', e nomes de objetos e/ou de alimentos, pelos quais os alunos já haviam nas aulas anteriores demonstrado apreço, como inhame, alface, pamonha e pastel.

Figura 1. Slide 31 da apresentação da aula 9 - 3 de agosto de 2020

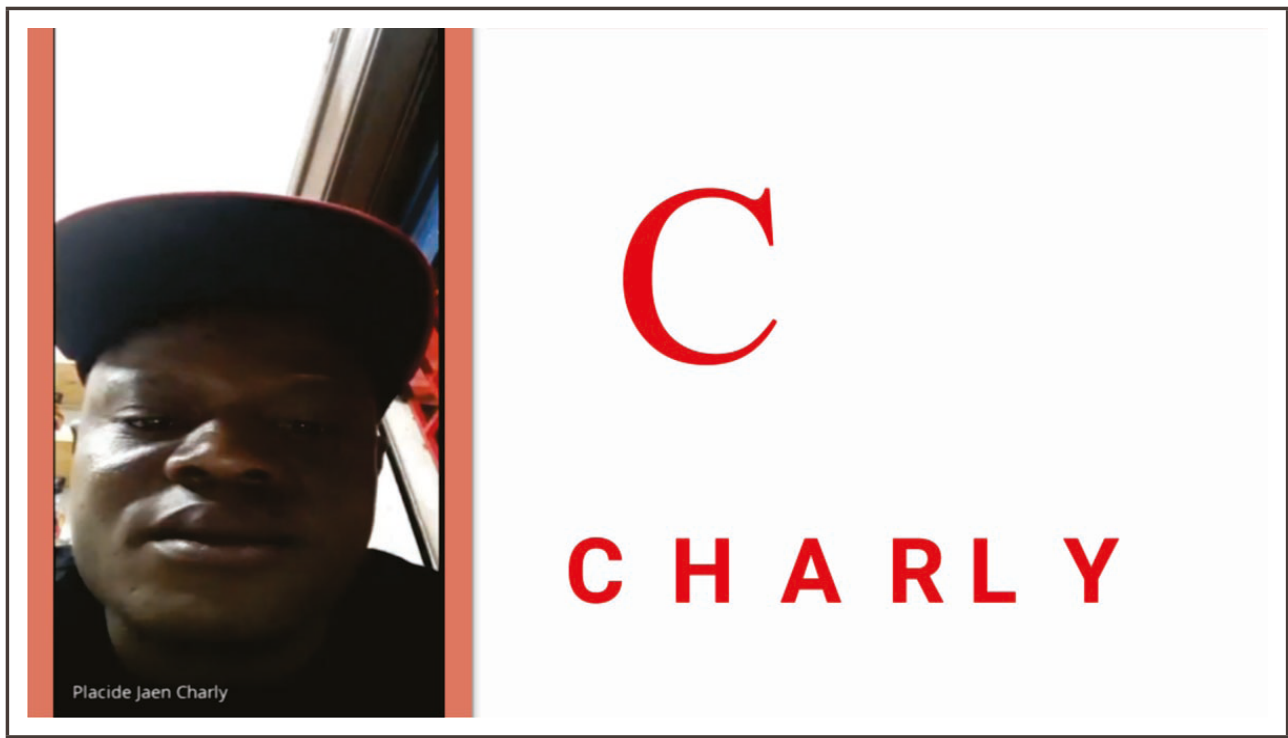

Fonte: Banco de dados do projeto MoVe.

[7]

[Transcrição de um trecho da nona aula, 3 de agosto de 2020]

Kamilla: Charly? Cê.

Charly: Kamilla!

Kamilla: Cê.

Charly: (...) Seis.

Kamilla: Cê.

Charly: Seis.

Kamilla: Isaque (...) diga cê para o Charly porque ele está falando seis.

Isaque: Charly?

Charly: Oi, Isaque.

Isaque: Cê.

Charly: Seis.

Isaque: Cê de Charly. 
Charly: Cê de Charly! Cê!

Kamilla: Cê.

Charly: Cê, (...) agá, (...) á, (...) érri, (...) éli, (...) ifisilon. (...) Charly.

Ao darmos seguimento ao livro didático Pode Entrar, adotamos a mesma abordagem para trabalhar o uso dos pronomes pessoais, priorizando sair dos modelos fixos e descontextualizados, para uma abordagem mais centrada no aluno, em que ele se sentisse incluído no processo de aprender. Elaboramos sentenças com informações reais da vida dos alunos e do mediador, tais como "Fritznel e Shelton são pais", "Eles são pais", "Cherna gosta de pamonha", "Ela gosta de pamonha", "O Alexis está usando terno", "Ele está usando terno", como nos mostra o recorte de um dos slides utilizados nessa aula.

Figura 2. Slide 19 da apresentação da aula 12 - 14 de agosto de 2020

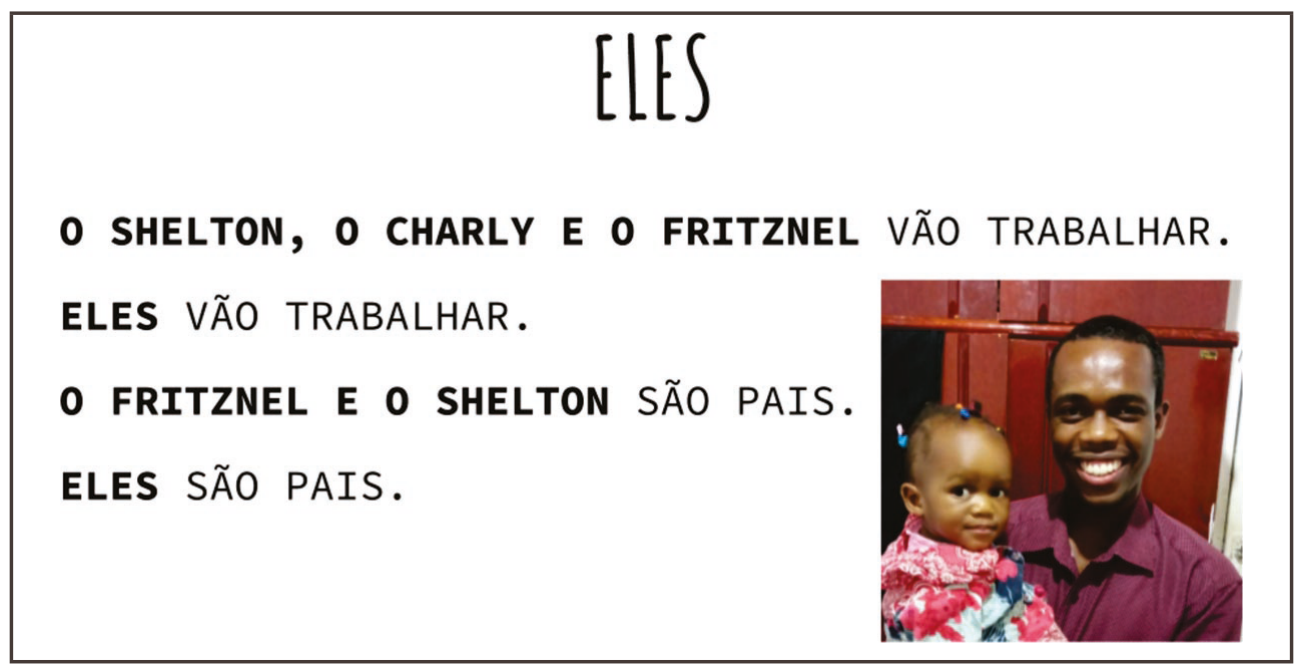

Fonte: Banco de dados do projeto MoVe.

Na continuidade, o segundo capítulo do livro didático Pode Entrar traz uma atividade que visa trabalhar os sentimentos e as características físicas das pessoas. Entretanto, as imagens são, em nossa opinião, pouco atrativas. Decidimos, então, colocar imagens representativas dos sentimentos e das características físicas, seguidas do conceito. Embora soubéssemos que seria difícil para eles compreenderem os conceitos a partir da leitura em português, consideramos que a língua de ancoragem poderia ser nosso apoio e daríamos aos alunos mais insumos linguísticos de português, como "Alegre/feliz' - a alegria e felicidade são sentimentos de prazer de viver, satisfação nas pessoas, costumam ser expressos por meio de sorrisos". Nos recortes próximos apresentamos parte do plano de aula, um exemplo de slide utilizado e o trecho da interação entre os licenciandos regentes e a aluna Cherna. 
Figura 3. Recorte do plano da aula 18 - 11 de setembro de 2020

\begin{tabular}{|c|c|c|}
\hline Estágio & Tempo & \multicolumn{1}{c|}{ Atividades e tarefas } \\
\hline Introdução de \\
conteúdo novo & $\mathbf{3 0 m}$ & $\begin{array}{l}\text { Etapa 2: } \\
\text { Isaque, a partir dos slides, trabalhará a parte secundária } \\
\text { do tópico 2.5 "Como me sinto e como sou..." da unidade 2 } \\
\text { da apostila "Pode entrar". Mostrando aos alunos caracterís- } \\
\text { ticas físicas de gente idosa (o), gorda(o), magra(o) e criança. } \\
\text { Kamilla, em seguida, fará um exercício de fixação "Co- } \\
\text { mo eu sou" com os alunos, que consiste em descrever os } \\
\text { colegas de turma, os professores regentes e algumas cele- } \\
\text { bridades aleatórias, previamente selecionadas. }\end{array}$ \\
\hline
\end{tabular}

Fonte: Banco de dados do projeto MoVe.

Figura 4. Slide 18 da apresentação da aula 18 - 11 de setembro de 2020

\section{Cherna}

- Alta

- Morena

- Cabelo preto

- Cabelo crespo

Fonte: Banco de dados do projeto MoVe.

[8]

[Transcrição de um trecho da décima oitava aula, 11 de setembro de 2020] Isaque: E essa moça?

Cherna: (...) Menina canta bonito

Isaque: É. Você conhece ela? É a Isa.

Cherna: É a Isa.

Isaque: Isso! Ela é o quê?

Cherna: Ela é cabelo preto, negra também (...) mais alta também (...) tem alegria também.

Com a nossa convivência com os alunos, aprendemos bastante sobre eles e decidimos aprofundar nos conteúdos abordados trazendo a temática feira de rua, um 
evento muito comum em Goiânia e, pelas nossas observações, frequentado pelos alunos. Nessa aula, apresentamos o vídeo "Feira livre: Mohamad dá dicas de como (re) aproveitar os alimentos e economizar | Mohamad no Nhac", disponível na plataforma YouTube.

O propósito do vídeo era apresentar uma feira, espaço de convivência social comum no Brasil, e averiguar se os alunos já conseguiam entender uma apresentação oral em português, com vocabulário mais informal. Além da apresentação do vídeo, realizamos uma atividade de feira on-line, a partir da qual trabalhamos o valor da moeda real, a ação de comprar, pagar e receber troco, como nos mostram as Figuras de 5 a 7.

Figura 5. Trecho do plano de aula 16 - 28 de setembro de 2020

\begin{tabular}{|c|c|l|}
\hline Estágio & Tempo & \multicolumn{1}{c|}{ Atividades e tarefas } \\
\hline $\begin{array}{l}\text { Introdução de } \\
\text { conteúdo novo }\end{array}$ & $\mathbf{4 0 m}$ & $\begin{array}{l}\text { Etapa 3: } \\
\text { Isaque realizará um questionário de múltipla escolha } \\
\text { para reafirmar o conteúdo "Pronomes Pessoais", "Adjeti- } \\
\text { vos Possessivos" e incluirá ao questionário o novo conte- } \\
\text { údo "Verbos" com ênfase no tópico 1.8 verbos 'Estar e Ir', } \\
\text { por meio de sentenças utilizadas em feiras livres. } \\
\text { Kamilla conduzirá com os alunos uma feira on-line, uti- } \\
\text { lizando uma tabela que consistirá em Quem? (a pessoa que } \\
\text { está vendendo), O quê? (o produto a ser comercializado), } \\
\text { Valor da compra (quanto vale aquele produto), Pagou com } \\
\text { (valor em dinheiro) e Troco. }\end{array}$ \\
\hline
\end{tabular}

Fonte: Banco de dados do projeto MoVe.

Figura 6. Feira on-line aula 16 - 28 de agosto de 2020

\begin{tabular}{|l|l|l|l|l|}
\hline \multicolumn{1}{|c|}{ Quem? } & O quê? & Valor da compra: & Pagou com: & Troco: \\
\hline Isaque & & & & \\
\hline Kamilla & & & & \\
\hline Cherna & & & & \\
\hline Fritznel & & & & \\
\hline Charly & & & & \\
\hline Shelton & & & & \\
\hline Pharex & & & & \\
\hline Widley & & & & \\
\hline
\end{tabular}

Fonte: Banco de dados do projeto MoVe. 
Figura 7. Feira on-line aula 16 - 28 de agosto de 2020

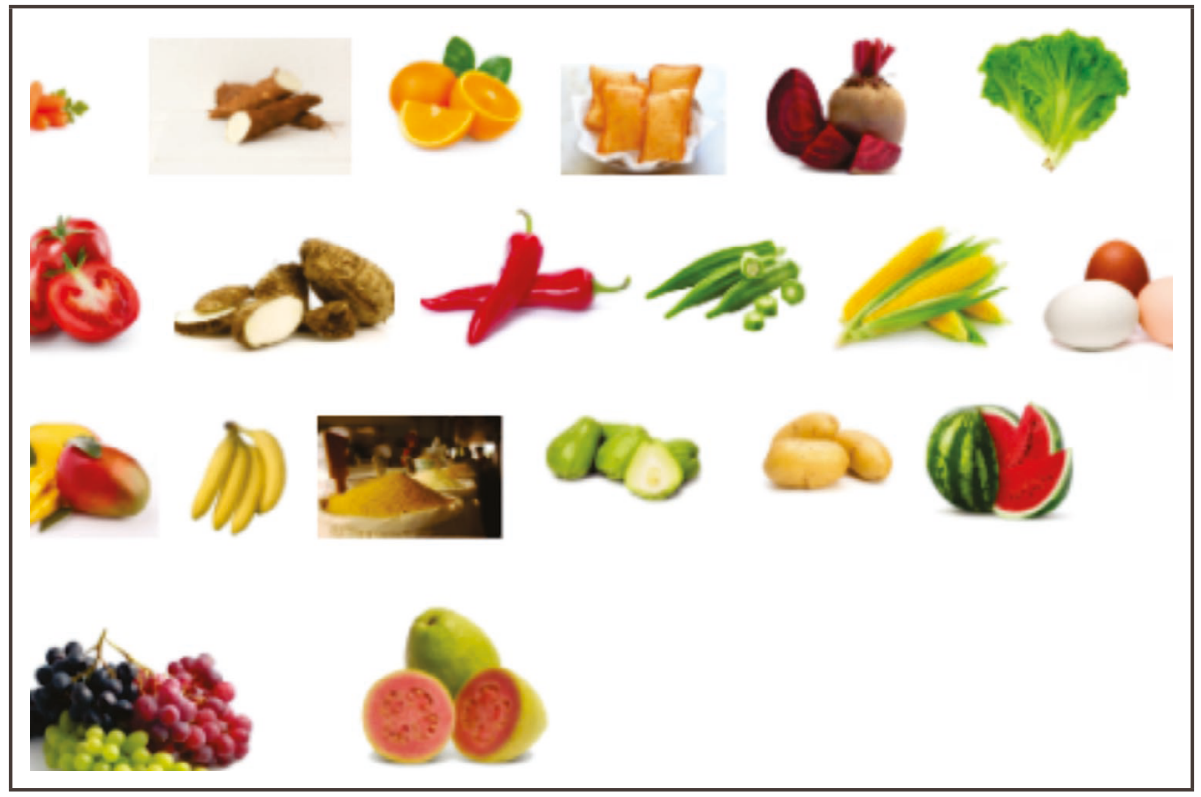

Fonte: Banco de dados do projeto MoVe.

Acrescentamos ainda nessa aula um material didático construído no aplicativo Word on-line, no formato de questionário, com sentenças preestabelecidas e com três possibilidades de respostas para a proposição, na modalidade arrasta e solta. A intenção era que o aluno escolhesse o pronome pessoal correto a partir da flexão do verbo e nós o arrastaríamos para dentro do par de chaves, soltando-o para que ele compusesse a sentença, como nos mostra a ilustração a seguir.

Figura 8. Exercício sobre o uso de pronomes pessoais da aula 16 - 28 de agosto de 2020

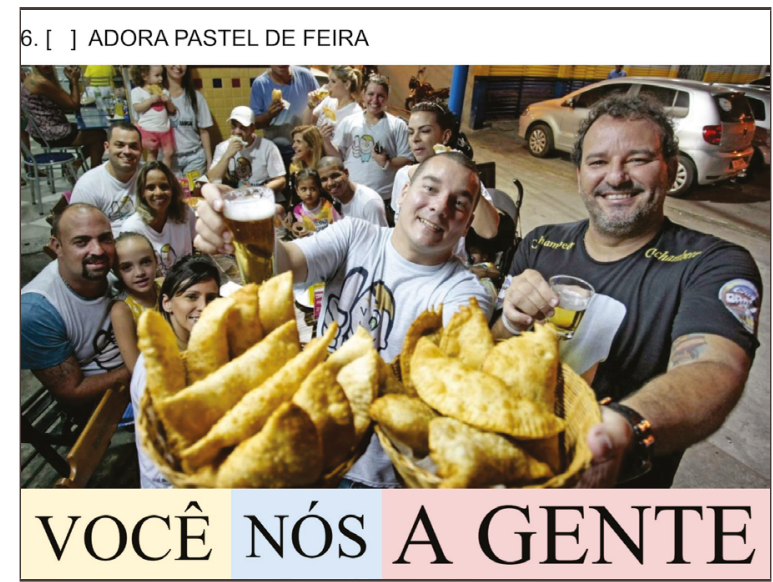

Fonte: Banco de dados do projeto MoVe. 
Contudo, no decorrer da atividade, percebemos que os alunos ainda não conseguiam definir a escolha do pronome pessoal considerando a declinação do verbo. De imediato, no curso da ação, ressignificamos o exercício e independentemente de qual pronome pessoal o aluno escolhesse, nós declinávamos o verbo para a flexão de pessoa e número corretos. Essa interação pode ser conferida no recorte 9, a seguir.

[9]

[Transcrição de um trecho da décima sexta aula, 28 de agosto de 2020]

Isaque: Aí Cherna, oh.

Cherna: Você gosta de pastel [lendo o slide]

Kamilla: Olha o pastel!

Isaque: [...] aqui óh... você adora pastel de feira.

Charly: Você adora pastel de feira.

Cherna: Você adora pastel de feira.

Isaque: Você adora, Cherna. Só que eu também gosto de pastel, e aí fica: Nós adoramos pastéis de feira. Charly?

Charly: Oi?

Isaque: Como é que ficou a sentença?

Charly: Nós adoramos pastéis de feira.

Isaque: Tem como também colocar "a gente". Aí ficaria a gente adora pastel de feira.

Charly: A gente adora pastel de feira.

Cherna: A gente adora pastel de feira.

A tomada de decisão na ação de mudar a perspectiva proposta para o exercício não só nos possibilitou trabalhar mais uma vez o uso de pronomes pessoais de acordo com o verbo, retomando o conteúdo, como também valorizar o nível de conhecimento do aluno da língua portuguesa, possibilitando-lhe ser o maestro de seu próprio processo de aprender, em que a estrutura linguística foi trabalhada a partir da perspectiva do aluno e não do planejamento do professor. Tal fato mostrou que incluir o aluno não é pressupor o que ele já internalizou, mas permitir-lhe mostrar o que ainda não aprendeu e o que ele pode aprender. O recorte na sequência mostra como Cherna compreendeu a flexão verbal e como Charly ainda está no processo de compreendê-la.

[10]

[Transcrição de um trecho da décima sexta aula, 28 de agosto de 2020]

Isaque: E agora, Charly?

Charly: Estão na banca de laranja.

Isaque: Quem estão na mesa de laranja?

Cherna: Ela.

Isaque: Eles, eles estão na banca de laranja. Se fosse eu, como ficaria Charly?

Cherna: Eu estou.

Isaque: Isso, Cherna! Eu estou na banca de laranja. É isso! 
[11]

[Transcrição de um trecho da sessão reflexiva sobre a décima sexta aula, 28 de agosto de 2020]

Isaque: Foi muito legal, porque a gente já trabalhou a questão do verbo, mesmo que não explicando o que é a conjugação. Então mudou de pessoa, e como é que fica? Teve uma hora que a Cherna já estava falando, sabe? colocando a conjugação correta, e assim... eu fiquei muito animado!

A observação de Isaque coaduna com a perspectiva reflexiva dos licenciandos docentes, na qual o processo de ensino-aprendizagem possui o foco no aluno, considerando o nível de aprendizagem dele e o movimento que ele está desenvolvendo para aprender o português.

Nessa perspectiva, os licenciandos regentes passaram a realizar na ação, não só a reflexão sobre o que estava ou não atendendo os alunos, como também a mudança no direcionamento da aula, no material didático, por fim, no modo de acolher um aluno de PLAc. É nesse sentido que apresentamos as considerações finais deste capítulo, aqui renomeadas para considerações reflexivas.

\section{Considerações finais}

Nossas considerações reflexivas iniciam-se com mudanças pontuais no material didático como a adoção definitiva de uso de letras em caixa alta para os slides ou em qualquer outra atividade que trazia texto escrito, evitar, na oralidade, o uso de palavras como 'isso', 'correto' e 'sim', quando o aluno acertava o que lhe era solicitado, pois os alunos as repetiam como se fossem parte das sentenças que estávamos trabaIhando, fazer uso de canções cuja letra trouxesse não apenas os termos que estavam sendo abordados, mas a temática, como a canção 'Meu bem, meu mal', de Caetano Veloso, abordando descrição subjetiva de pessoas e o uso de adjetivos possessivos, nas aulas 13, 14 e 15. 'Normal É Ser Diferente', do grupo Grandes Pequeninos, que também trouxe a temática características físicas, assunto também presente na aula 18. 'Família', do grupo Titãs, mencionando os componentes familiares, tema das aulas 21 e 22.

Passamos a utilizar jogos de combinação de imagens e texto escrito, como o arrasta-solta mostrado na atividade com pronomes pessoais e flexão verbal, jogos de roleta, nos quais o aluno contemplado fala uma palavra que tenha a letra inicial sorteada, jogos de abrir a caixa, em que o aluno escolhe um número e depara-se com pronomes, adjetivos descritivos de emoções ou de características físicas e precisa falar uma frase a partir do termo encontrado, e jogos de cartas aleatórias, cuja face das cartas apresenta uma pergunta, iniciada por um pronome interrogativo e o aluno precisa respondê-la. Todos esses jogos foram criados por meio da plataforma Wordwall.net. 
Em uma perspectiva mais ampla, refletir sobre o ensino de PLAc nos fez mudar a aula de quarta-feira para segunda-feira, respeitando a liberdade religiosa, visto que as quartas-feiras são dias de culto e os alunos frequentam assiduamente esse evento. Assumimos que mesmo quando o aluno está com problemas no microfone por não conseguir acioná-lo ou está sem um fone, ele é mencionado na aula, as atividades são dirigidas a ele, mesmo sem nenhum retorno de áudio dele.

Revisitar os arquivos das aulas nos fez refletir sobre a nossa condição de professores regentes e como esse processo é determinante para repensar e nos afirmarmos como sujeitos, numa via dupla, pois, na função de professores de língua, nós estamos também aprendendo. Houve situações em que os alunos estavam em locais incomuns para uma sala de aula na concepção de um ambiente escolar, como no supermercado, no automóvel ou na residência de amigos e, para não perderem a oportunidade de acompanhar as aulas, conectavam-se com os seus celulares e se faziam presentes na sala de aula virtual.

Nossa experiência, desde o início do projeto, pode ser representada por uma diversidade de emoções. Sentimo-nos alegres, tristes, tensos, calmos, eufóricos, mas o que o Projeto de Ensino-extensão 'MoVe' mais nos proporcionou aprender até o momento é justamente como fortalecer a relação conosco mesmo e com o outro. Choramos bastante, rimos mais e sabemos que a jornada da turma Acolher A1 apenas começou. Nós achávamos que tínhamos o controle do que e como ensinar, mas aprendemos que controle não existe. Não há como prever aonde cada aluno pode chegar no processo de aprendizagem de PLAc e nem em como vamos nos construindo como professores. Aprendemos que precisamos nos permitir alçar voos. Hoje, não somos mais os mesmos, nós podemos até nos comparar ao que já fomos, mas nunca voltar a ser o que éramos.

\section{Referências}

FEITOSA, J. et al. Pode Entrar: Português do Brasil para refugiadas e refugiados. São Paulo, 2015.

FIGUEIREDO, F. J. Q. de. Aprendendo com os erros: uma perspectiva comunicativa do ensino de línguas. 3. ed. Goiânia: Editora UFG, 2015.

LUVIZARI-MURAD, L. H. Aprendizagem de alemão e português via teletandem: um estudo com base na teoria da atividade. 2011. 204 f. Tese (Doutorado em Estudos Linguísticos) - Instituto de Biociências, Letras e Ciências Exatas, Universidade Estadual Paulista, São José do Rio Preto, 2011. 
SILVA, S. V. da. O processo ensino-aprendizagem de línguas em teletandem: um estudo na área de Turismo. 2012. 293 f. Tese (Doutorado em Letras e Linguística) - Faculdade de Letras, Universidade Federal de Goiás, Goiânia, 2012.

SILVA, S. V.; F. F. J. Q. A telecolaboração como um recurso para o processo de aprendizagem de línguas em contextos tecnológicos. In: V CLAFPL (V Congresso Latino-Americano de Formação de Professores de Línguas), 2015, Goiânia. Anais [...]. Goiânia: Gráfica da UFG, v. 1. p. 49-58, 2015.

VYGOTSKY, L. S. A formação social da mente: o desenvolvimento dos processos psicológicos. São Paulo: Martins Fontes, 1998. 


\section{O ACOLHER E O SABER: EXPERIÊNCIAS COM O ENSINO DE PLAC MEDIADO POR TECNOLOGIA DIGITAL PARA MIGRANTES HAITIANOS}

Hamayana Silva Melo Suelene Vaz da Silva
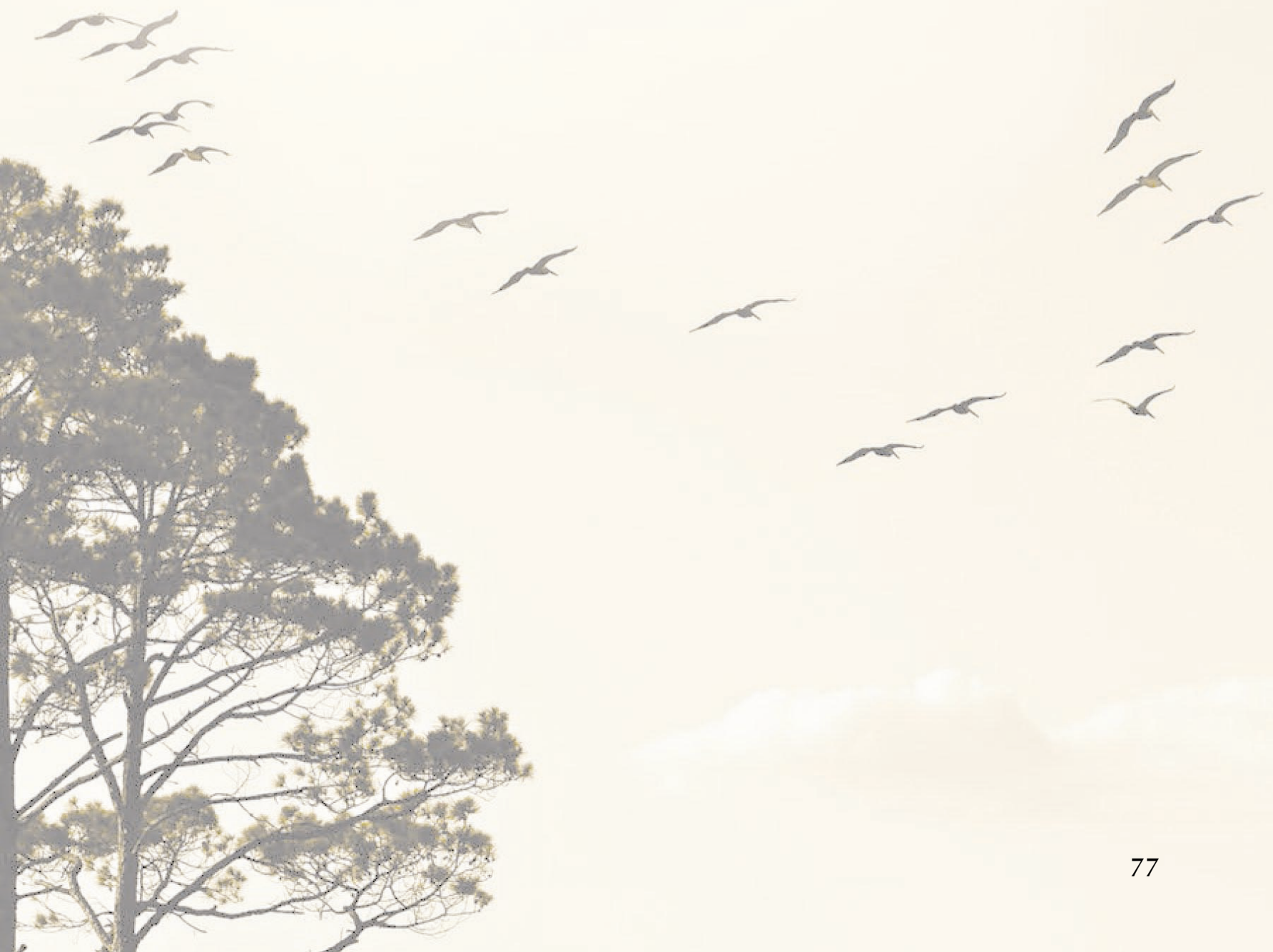
Resumo: Este artigo tem por objetivo apresentar alguns aspectos do percurso de formação a partir do ensino do ensino de Português como Língua de Acolhimento (PLAc) na ação advinda do projeto de Ensino-extensão 'Movimentos migratórios em $\mathrm{V}$ : ensino-aprendizagem de português para falantes de outras línguas'. As aulas são ministradas para um grupo de 19 haitianos, residentes em Goiânia, às segundas e sextas-feiras, das $19 \mathrm{~h}$ às 20h30, na modalidade síncrona, via plataforma de webconferência Google Meet. Ao Google Meet somam-se a plataforma Google Classroom, utilizada como ambiente assíncrono para a disposição das tarefas construídas para os alunos a partir do conteúdo trabalhado nas aulas síncronas, e o aplicativo WhatsApp, como meio midiático para comunicação entre regentes e alunos, para a prática das habilidades de produção e de compreensão oral e escrita e para promover a aproximação afetiva entre regentes e alunos. A abordagem adotada segue metodologias ativas de ensino-aprendizagem de línguas ao mesmo tempo que trabalha o PLAc como meio para a integração dos alunos haitianos à comunidade goiana. O conteúdo segue a distribuição das temáticas e de estruturas linguísticas do livro Pode Entrar, elaborado pela equipe do Cursinho Popular Mafalda, com o apoio da Cáritas Arquidiocesana de São Paulo. Contudo, o conteúdo é ressignificado sob a orientação de uma professora orientadora para melhor se adequar ao nível de língua portuguesa dos alunos, bem como à perspectiva do acolhimento.

Palavras-chave: Experiência docente. Ensino-aprendizagem de PLAc. Haitianos. Tecnologias digitais.

\section{O trabalho docente em ambiente virtual}

Darticipar da etapa virtual do ensino de Português como Língua de Acolhimento (PLAC) na modalidade de ensino remoto no projeto de Ensino-extensão 'Movimentos Migratórios em V: ensino-aprendizagem de português para falantes de outras línguas - MoVe' tem tido um significado ímpar na formação docente dos alunos de Licenciatura em Letras: Língua Portuguesa, do Instituto Federal de Educação, Ciência e Tecnologia de Goiás (IFG), câmpus Goiânia. Embora a razão de as aulas estarem ocorrendo em contexto virtual de ensino seja devido à pandemia causada pela Covid-19, tal experiência docente em contexto de ensino virtual seria dificilmente contemplada no curso de Letras. Assim, neste capítulo, abordamos a alegria pelo trabalho desenvolvido entre uma aluna de licenciatura e a orientadora no processo de planejar aulas e de ensinar Português como Língua de Acolhimento (PLAc) para uma turma de migrantes haitianos denominada Acolher A2 +.

Trabalhar com o ensino de PLAc não é uma novidade para alguns dos licenciandos em Letras do IFG, pois essa perspectiva de ensino, em contexto presencial, iniciou-se em agosto de 2018. Nesse período, os migrantes estavam no mesmo espaço geográfico que os regentes, o que possibilitava um contato mais direto com eles e, por conseguinte, perceber quais eram suas necessidades em relação à aprendizagem de português. Entre as dificuldades enfrentadas pelos alunos no período de aulas presenciais, destacamos duas que mais desencadearam a ausência deles nas 
aulas: acesso ao câmpus Goiânia, local onde as aulas aconteciam e horários de trabalho ou de eventos na igreja, que os alunos frequentavam, coincidindo com os horários das aulas.

No ambiente virtual, a mobilidade de deslocamento e de horários pode ser mais bem flexibilizada, porém outros fatores passaram a interferir no bom andamento das aulas, como a ausência de um computador em casa, celulares com baixa interatividade para aplicativos, dados insuficientes para acessar a internet, letramento digital quase inexistente e ainda a própria rotina da casa, que passou a fazer parte da sala de aula de Plac. Por essas razões, aprendemos que, no contexto de ensino remoto, os problemas situam-se em outras esferas e requerem uma atenção redobrada do professor para outras vulnerabilidades dos alunos, as quais também se relacionam às questões sociais e econômicas.

O projeto MoVe, nesse sentido, revelou-se na oportunidade de problematizar o ensino de PLAc em uma situação social, que trazia à tona não só a necessidade de letramento digital e de atenção ao aluno como um sujeito, que deseja aprender, mas que precisa superar barreiras, muitas vezes impostas pela própria condição de sujeito à margem dos benefícios necessários para viver bem na comunidade de acoIhimento.

\section{Os alunos}

A princípio, a Turma Acolher A2 + possuía dez alunos haitianos adultos matriculados. Essa realidade mudou quando percebemos que havia outros alunos assistindo às aulas por meio do compartilhamento de um mesmo equipamento. Assim, a turma passou a ser composta por 19 alunos, de nacionalidade haitiana, todos residentes na região metropolitana de Goiânia. São 14 homens e cinco mulheres, falantes de português nível A2, tendo como referência as competências descritas no Quadro Comum Europeu de Referência para Línguas (CEFR). O símbolo + foi acrescido para diferenciar essa turma de outra turma da ação de ensino de PLAc do MoVe, que também foi classificada no nível A2.

A maioria dos alunos trabalhava no período diurno e, à noite, por fazerem parte de uma comunidade religiosa, assistem aos cultos da igreja. Tivemos, por essa razão, que adequar as aulas para os dias e horários em que eles tinham disponibilidade para estar em casa ou na casa de um amigo e acessar o ambiente virtual para as aulas. Alteramos os horários de sábados, das $18 \mathrm{~h}$ às $20 \mathrm{~h}$, quando presenciais, para as segundas e sextas-feiras, das $19 \mathrm{~h}$ às $20 \mathrm{~h} 30$.

O maior problema enfrentado pelos alunos para efetivar esse acesso relaciona-se a uma internet sem qualidade suficiente para sustentar uma conexão de uma hora e trinta minutos, duas vezes por semana, e ainda um pacote de dados suficientes para acesso a outros ambientes virtuais na modalidade assíncrona. Esses fatores são os que 
mais interferiram no bom andamento das aulas e causaram a ausência dos alunos em muitas delas. Na tentativa de atenuar essa dificuldade, o IFG aprovou uma ajuda de custo de R\$10,00, por aula síncrona assistida, para subsidiar o pacote de dados de internet e, assim, viabilizar a participação dos alunos nas aulas, mas problemas de baixa qualidade dos aparelhos ainda causaram interferências no áudio e acabaram por prejudicar a compreensão das falas, por conseguinte, dos conteúdos.

Mesmo assim, esse é um problema que se situa em um âmbito maior, ainda distante de soluções por parte da equipe do projeto. Em contrapartida, os alunos raramente faltavam às aulas, mesmo tendo que deixar as câmeras fechadas para economizar dados de internet, eles se faziam presentes e se dedicavam ao aprimoramento do conhecimento da língua portuguesa. São essas dimensões que nos motivaram a seguir em frente e fazer o nosso melhor pelo acolhimento dos alunos.

\section{O material de base para as aulas e os recursos digitais utilizados}

As regências no projeto nos meses de agosto e setembro foram desenvolvidas juntamente com o colega licenciando do curso de Letras do $3^{\circ}$ período, Adão Martins dos Santos. Essa parceria aconteceu durante a construção dos planos de aula, a elaboração de materiais didáticos e as execuções das aulas nos dois momentos: síncrono, utilizando o Google Meet (GMeet), e assíncrono, por meio do Google Classroom (GClass), com o auxílio do WhatsApp (Wpp).

O material de apoio escolhido pelo projeto para dar suporte à construção e elaboração das aulas foi o livro Pode Entrar, produzido pela equipe do Cursinho Popular Mafalda, com o apoio da Cáritas Arquidiocesana de São Paulo. As aulas, embora pautadas nesse livro, foram pensadas para atender às necessidades dos alunos e elaboradas de maneira que promovessem o uso da língua em interação a partir de seu uso real e significativo. A escolha da temática das aulas apoiava-se nos temas propostos no livro de apoio. Fazíamos a pesquisa de imagens na internet para ilustrar a temática e buscávamos enriquecer o desenvolvimento do tópico com a inserção de músicas, contos e/ou poemas, sempre considerando o que melhor se adequasse ao assunto e também à realidade e necessidade dos alunos. Na elaboração do material, atentávamo-nos ainda para questões de estética e de apresentação do material, como a qualidade das imagens e dos vídeos, as cores e o tamanho da fonte para os textos escritos que estariam dispostos na tela dos celulares dos alunos.

Para ampliar os recursos oferecidos pelo GMeet, a execução das aulas também foi planejada com a utilização de outras ferramentas on-line como (1) o Google Slides Apresentações, utilizado para a elaboração de material com imagens, vídeos e para inserir informações sobre o conteúdo apresentado; (2) o Questionários e/ou Formulários Google, usado para a criação de questionários de múltipla escolha ou de respostas curtas, no formato de pergunta-resposta; (3) o CrossLabs e o Wordwall, como 
apoio para a inserção de ludicidade nas aulas por meio da criação de caça-palavras, jogos de adivinhações, de memória, forca, etc.; e (4) o YouTube, utilizado para o compartilhamento de vídeos, principalmente de curtas, videoclipes de músicas, propagandas e documentários. Todos esses recursos propiciaram o enriquecimento das aulas e as tornaram mais dinâmicas e interativas.

Sobre o papel do professor(a) Santos (2018, p. 30) afirma que:

É fundamental que o professor exerça o papel de facilitador e mediador no processo de ensino e aprendizagem e faça uso dos avanços trazidos pelas tecnologias, tais como a constante e rápida comunicação entre as pessoas, que interferem na vida cotidiana e em todas as ações, nas condições de pensar e de representar a realidade.

Apesar do pouco letramento dos nossos alunos e da dificuldade que apresentaram ao lidar com as ferramentas digitais, uma vez que dispunham apenas de um aparelho celular e com poucos recursos para ampliar o letramento digital, eles mantiveram uma atenção singular nas aulas. Por esse motivo, a nossa preocupação com a seleção e produção dos materiais de aula, como: criar tutoriais, selecionar músicas, escolher vídeos, pesquisar poemas que atendessem ao conteúdo apresentado, elaborar atividades e pensar a execução das aulas, mesmo que apoiados no material didático e os recursos digitais que iríamos trabalhar na sala de aula, e com pouco recurso de dados, permitiram que o aluno fosse alcançado em suas competências comunicativas. Nessa perspectiva, trabalhamos a oralidade com a leitura de poemas, contos, crônicas e letras de música.

\section{As aulas e as estratégias de Ensino}

O início do trabalho veio acompanhado de muitas perguntas, uma delas era como seria ensinar português na perspectiva de PLAc na modalidade do ensino remoto. A princípio, as dificuldades que se apresentaram foram tecnológicas: estudar sobre as plataformas, compreender o funcionamento e aplicabilidade de algumas ferramentas encontradas no ambiente virtual associadas ao GClass e ao GMeet. Criar tutoriais para auxiliar os alunos nas plataformas que seriam usadas nas aulas. Com o caminhar, os desafios tomaram outras dimensões: idealizar, planejar e executar as aulas nesses ambientes não familiares para nós ou para os alunos.

Iniciamos o período letivo contatando os alunos via mensagem em um grupo compartilhado entre a professora, a orientadora e os alunos da turma por meio da ferramenta de Wpp. Nessas mensagens, além de lhes dar as boas-vindas às aulas de PLAc, postamos um material de apoio explicando como acessar a plataforma que seria utilizada para as aulas síncronas, o GMeet. Esse material constituiu-se em um tutorial, no formato de vídeo, gravado via aplicativo Az Screen Recorder, disponibilizado 
na playstore de celular Android. O aplicativo possibilita ao usuário gravar a tela do celular simultaneamente à narrativa oral. Esse vídeo foi fundamental para os alunos acessarem o ambiente de aula e, assim, minimizar possíveis dificuldades de primeiro acesso.

A primeira aula foi destinada ao acolhimento dos alunos. Nós os recepcionamos e apresentamos as principais plataformas que nos acompanhariam no processo de ensino on-line. Reforçando o conhecimento prévio que eles obtiveram assistindo ao vídeo, explicamos o passo a passo já enviado para eles no grupo de Wpp. Desde o primeiro contato, percebi que o filtro afetivo reduzido (KRASHEN, 1985) entre alunos/professora era evidente. Os alunos são sempre receptivos e preocupados em participar das aulas mesmo com as dificuldades de acesso à internet. Infelizmente, esse acesso foi um dos maiores problemas encontrados no decorrer das aulas.

O conteúdo trabalhado na primeira aula abordou cumprimentos básicos, utilizados em situações formais e informais, com ênfase maior em expressões de saudações mais utilizadas em ambientes formais, considerando que os alunos já estão há algum tempo no Brasil e, portanto, acostumados com algumas expressões informais de cumprimentos. Para ilustrar essa aula, apresentamos um trecho do diálogo entre um aluno e a professora, o qual mostra o nível de fluência de português de JJ, quanto ao uso de cumprimentos informais, bem como um problema na conexão dele com o GMeet, o que atrapalhou o fechamento da tarefa.

\section{[1]}

[Aula síncrona, 8 de julho de 2020]

JJ: Bom dia, Sr! Meu nome é JJ, eu tô aqui pa fazer uma entrevista com você.

Professora: Você vai me chamar de Sr?

JJ: Não sei. (aluno riu).

Professora: Pode ser assim: Tudo bem com a sra. ou tudo bem com você?

JJ: Ok. Pode ser assim, pode ser assim.

(falha no áudio do aluno)

[...]

JJ: Muito obligada. Ficô um plazer pla mim pla conversá com você.

Intervenção da professora: Muito obrigado. Isso mesmo! E eu vou falar: Eu que agradeço!

Seguimos o trabalho com a língua portuguesa abordando descrições de pessoas, com o objetivo de auxiliar os alunos na compreensão de como fazer a descrição por uma abordagem mais subjetiva e que eles pudessem fazê-la sem a intervenção do professor. Para isso, utilizamos um material a partir de situações reais, que pudessem desencadear o interesse nos alunos. O resultado foi positivo, pois eles acabaram conectando seus sentimentos com o que fora apresentado e houve desde euforia à melancolia, pois sentimentos como saudade e alegria estiveram presentes na aula. 
Figura 1. Material elaborado para a aula
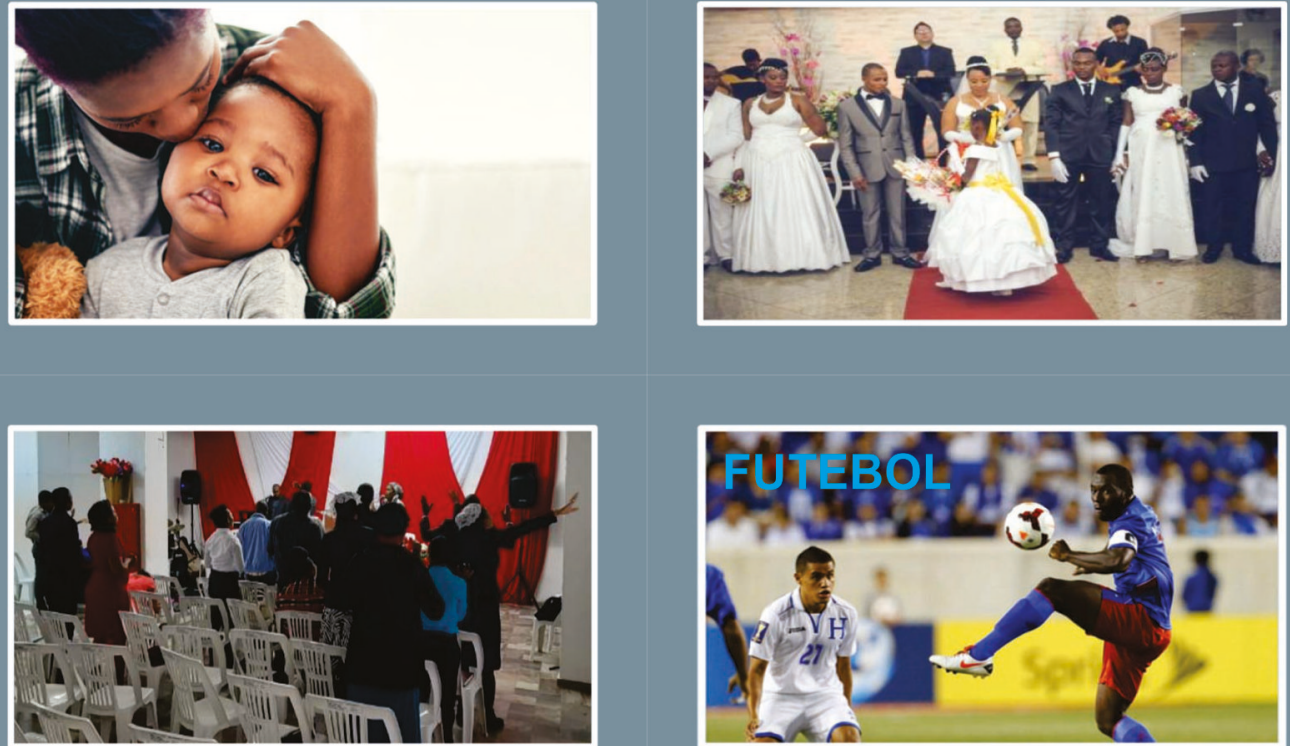

Fonte: Dados deste estudo.

Solicitamos, então, para a prática do conteúdo trabalhado, uma tarefa em que os alunos tinham que produzir um vídeo apresentando suas características pessoais e uma outra tarefa escrita, na qual eles deveriam descrever alguém que eles admiravam. Nessa tarefa, pudemos perceber que existem problemas na estrutura da língua, mas o nosso foco era na competência comunicativa, por esse motivo, deixamos nossos alunos se expressarem livremente, pois acreditamos que esses desvios seriam reduzidos à medida que as interações em sala de aula fossem ocorrendo. A imagem a seguir exemplifica essa tarefa.

Figura 2. Texto da tarefa sobre descrição

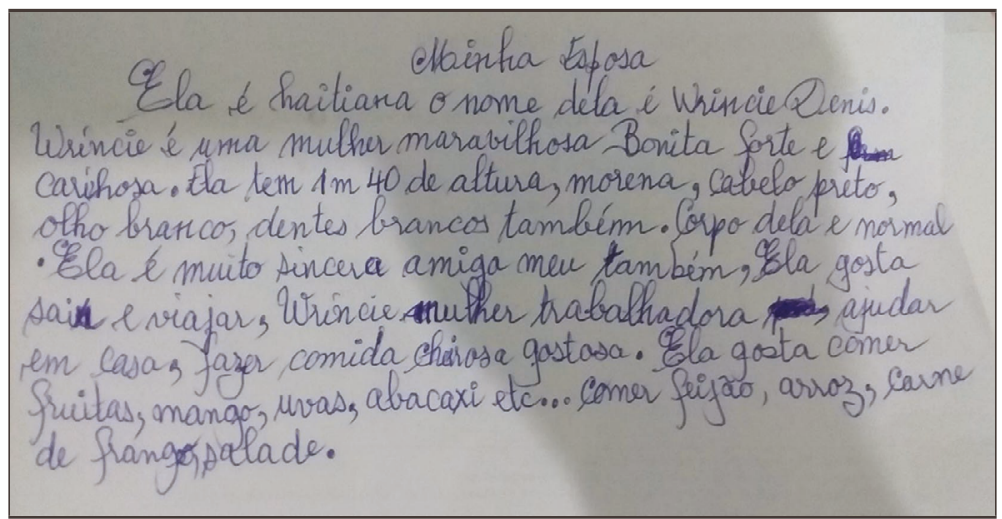

Fonte: Dados deste estudo. 
Somente 11 alunos conseguiram fazer a tarefa solicitada e, destes, apenas nove a anexaram na plataforma CClass e dois alunos ficaram no status de tentativas. Mesmo com o nosso auxílio, observamos que alguns alunos ainda encontravam dificuldades para enviar a tarefa pelo GClass. Com base nas anotações que fizemos sobre essas dificuldades a partir de uma conversa com os alunos, planejamos a nossa aula tentando acrescentar mais estratégias, fizemos slides com prints do passo a passo para acesso à Plataforma, bem como o texto escrito. Ainda acrescentamos outro vídeo em forma de tutorial, assim eles tiveram acesso à imagem, à leitura e ao áudio e vídeo. Algumas dessas imagens são:

Figura 3. Material elaborado para a aula

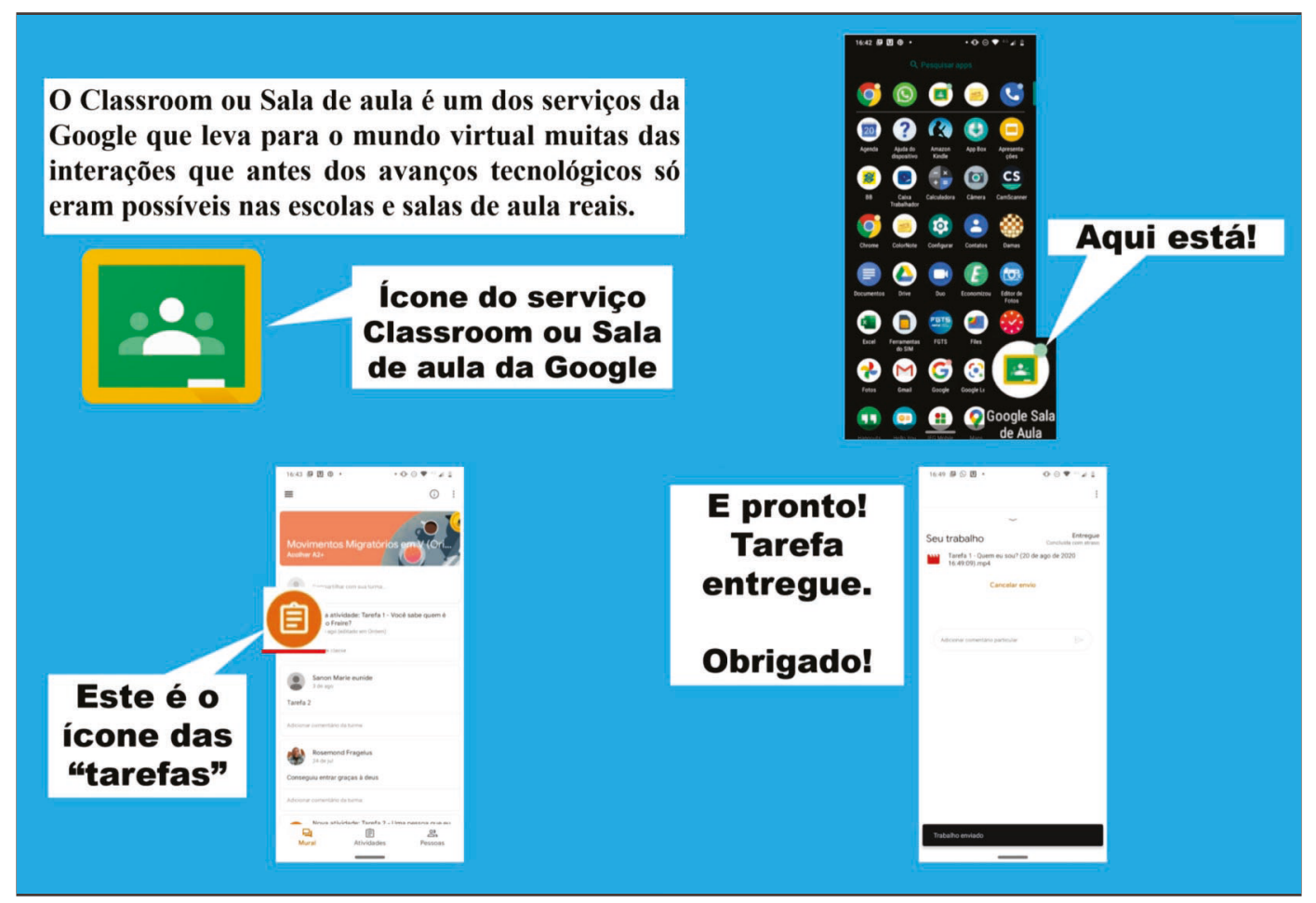

Fonte: Dados deste estudo.

Naquele momento, sentimos que nossos recursos se esgotaram e alguns alunos ainda encontravam dificuldades para acessar a plataforma das aulas assíncronas. Então, propusemos auxílio individual a cada aluno em horários diferentes das aulas síncronas para fazer o passo a passo sobre o uso do GClass. Dessa maneira, esperávamos alcançar o aluno e ajudá-lo de maneira mais efetiva no seu letramento digital. Contudo, essa intervenção não resultou em acesso à plataforma por eles. Enquanto lidávamos com esse problema, ainda nos sentíamos um pouco perdidos no processo de planejamento das aulas, pois o material muitas vezes parecia visar apenas a um trabalho mais pontual com a estrutura gramatical do português, abordando aspectos co- 
mo uso de artigos, pronomes, advérbios e locuções adverbiais. Na aula em que abordamos descrição de cenas e cenários, as falas dos alunos focaram mais na descrição dos objetos específicos, sem suscitar neles a relação desses objetos com os cenários ou mesmo com as cenas apresentadas nas imagens. A figura e o excerto da interação na aula ilustram nossa observação.

Figura 4. Print de tela da aula

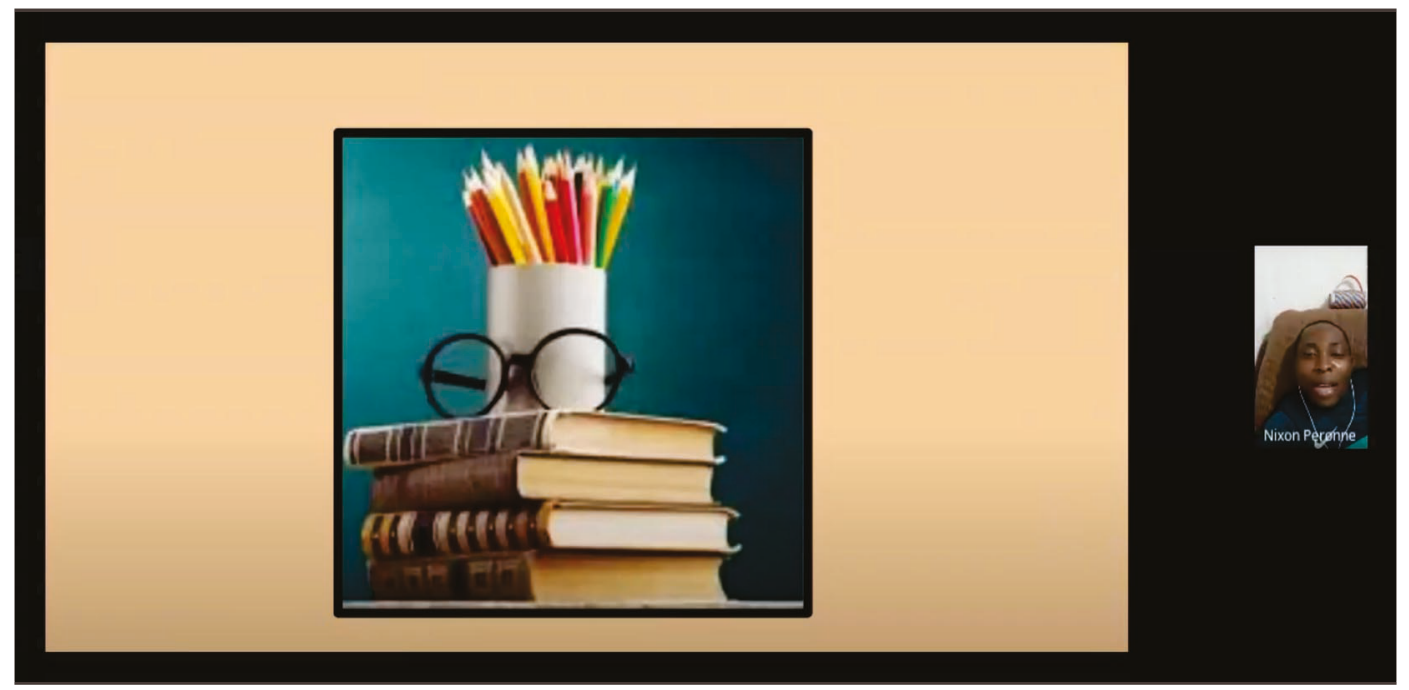

Fonte: Dados deste estudo.

[2]

[Transcrição da aula 7, dia 27 de julho de 2020]

Hana: Nessa foto o que vocês veem?

LR: Tem lápis, copos, óculos e livros.

NX: Tem lápis... tem os copos... e livros.

SM: Tem lápis e livros.

Hana: Onde estão os lápis?

LR: Os lápis estão... estão em cima dos livros.

NX: Em cima dos... livros.

SM: Assim...

Hana: Ahhh, eu tenho também o quê? Vocês falaram outra coisa que eu não escutei direito. Esses redondinhos aí é o quê?

NX: Um copo

RF: Um copo

É um óculos?

NX: óculos... um copo.

Hana: E o óculos está onde?

NX: Em cima dos livros

LR: Sobre os livros.

Hana: Está sobre os livros ou em cima dos livros, muito bem! 
Embora a descrição de objetos tenha dominado a produção oral dos alunos, percebemos que eles haviam entendido o uso de termos no singular e plural, bem como de vocábulos referentes à localização espacial. Todavia, essa aula nos fez refletir que precisávamos dar mais autonomia para o aluno no uso da oralidade, pois a fala espontânea poderia ultrapassar o uso puro do português em função de um item gramatical para a utilização da língua para a comunicação, com função real na comunidade, conforme defende o PLAc (GROSSO, 2010; SÃO BERNARDO, 2016). Percebemos o quanto a forma como abordamos a temática e as perguntas que fazemos são importantes para uma aula de cunho comunicativo.

Na sessão reflexiva, a orientadora auxiliou-nos na reflexão sobre o papel do professor e do aprendiz de PLAc, especificamente em como o foco da aprendizagem é o aluno, sendo o professor o mediador, apoiando o aluno na construção do conhecimento, pois ele próprio é capaz de realizar essa construção. Assim, auxiliar o aluno na sala de aula com perguntas fechadas, esperando deles respostas também fechadas não é mediar. A sessão de reflexão propiciou-nos ainda o entendimento da diferença entre a ação de conduzir, levar e a de mediar, pois é fundamental oportunizar ao aprendiz que ele próprio faça suas descobertas, sem decidir por ele.

Outro ponto que nos fez refletir foi o formato das aulas. Estávamos muito limitados na construção e elaboração do material a ser apresentado na aula. Diante disso, mais uma vez foi preciso entender que o ensino não era pautado apenas em elementos gramaticais, mas por questões que sempre colocam o aluno no centro da aprendizagem. O que queremos fazer nas nossas aulas? O que queremos levar para nosso aluno? Diante disso, retomamos as palavras de Barbosa e Amaral (2014, p. 269), as quais nos ajudaram a compreender que:

[a]prender a língua do país de acolhimento favorece a inclusão social e profissional dos imigrantes em geral. Esse conhecimento gera maior igualdade de oportunidades para todos, facilita o exercício da cidadania e potencia qualificações enriquecedoras para quem chega e quem acolhe.

À medida que as aulas foram acontecendo, observamos que as sessões reflexivas estavam gerando resultados. Buscou-se atender à perspectiva mais crítica na elaboração e execução das aulas. Criamos um material trazendo a temática sociedade e educação, a partir da proposta do livro Pode Entrar, no capítulo 3, que enfoca a função da educação para uma sociedade mais humanizada. Levamos para a sala de aula a problematização acerca do papel do sujeito, enquanto cidadão dotado de direitos e deveres, pertencente a uma sociedade socioculturalmente construída. Trabalhamos o poema do educador Paulo Freire 'A escola', e os alunos puderam ler e interpretá-lo.

Em continuidade ao nosso trabalho, no que compete ao pensar, elaborar e executar o material didático, buscamos fazer um material com cenas que se aproxi- 
massem da realidade dos alunos. O nosso esforço trouxe-nos muitas alegrias. No decorrer da aula, os alunos, ao perceberem a imagem de uma sala de aula com alunos haitianos, ficaram surpresos e ao mesmo tempo tentaram se reconhecer na imagem. O sentimento de pertencimento, de fazer parte, fazia com que se sentissem acolhidos e esse foi um momento de felicidade para ambos os lados. Tal sentimento ficou explícito, como nos mostra o próximo excerto, que traz a imagem e a interação entre a professora e três alunos.

Figura 5. Imagem ilustrativa de uma sala de aula

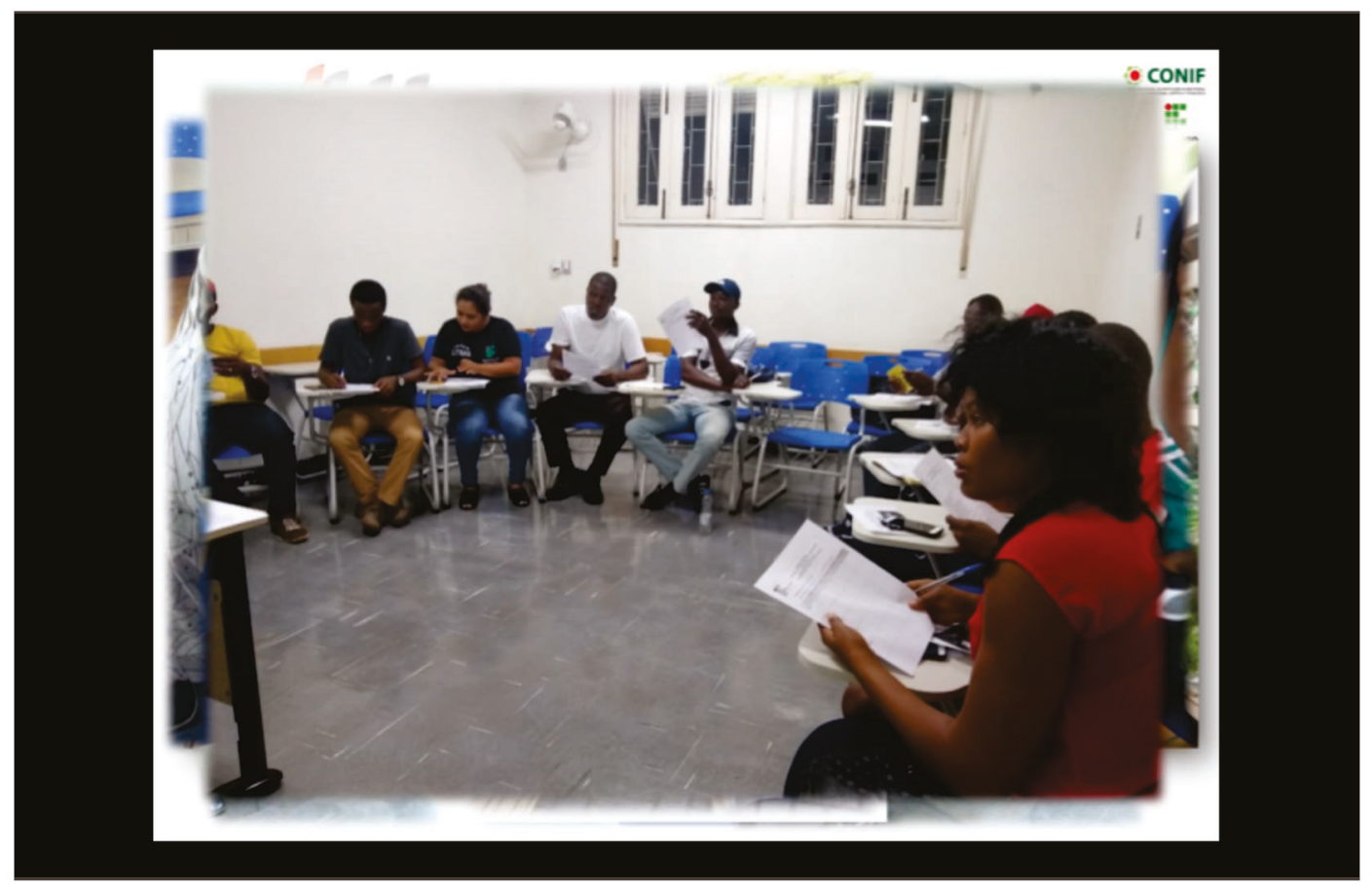

Fonte: Dados deste estudo.

Considerando que o foco das aulas é a comunicação oral, para promover debates fizemos o uso de letras de músicas que trouxessem temáticas que se relacionam com o assunto proposto. A música 'Tocando em frente', do cantor Almir Sater, por exemplo, foi utilizada para a temática de migração, enfocando os lugares por onde as pessoas passam, as experiências que vivenciam, sejam negativas ou não, e o que elas aprendem, constroem e levam para a vida. Cantar e interpretar a letra da música foi um momento muito bonito e de descontração da nossa aula. Os alunos acompanharam atentamente, assim como participaram de forma ativa. Como essa foi a primeira apresentação de música na sala de aula, ficamos felizes com a receptividade dos alunos e decidimos que levaríamos esse recurso em aulas futuras. A seguir, apresentamos a fala de um aluno sobre a interpretação de um trecho da música. 
Figura 6. Texto da canção 'Tocando em frente'

Tocando em frente - Almir Sater Ando devagar porque já tive pressa E levo esse sorriso

Porque já chorei demais Hoje me sinto mais forte Mais feliz, quem sabe Só levo a certeza

De que muito pouco sei

Ou nada sei

Conhecer as manhas e as manhãs

O sabor das massas e das maçãs

É preciso amor pra poder pulsar

É preciso paz pra poder sorrir

É preciso a chuva para florir

Penso que cumprir a vida

Seja simplesmente
Compreender a marcha

$E$ ir tocando em frente

Como um velho boiadeiro

Levando a boiada

Eu vou tocando os dias

Pela longa estrada, eu vou

Estrada eu sou

Conhecer as manhas e as manhãs

O sabor das massas e das maçãs

É preciso amor pra poder pulsar

É preciso paz pra poder sorrir

É preciso a chuva para florir

Todo mundo ama um dia

Todo mundo chora

Um dia a gente chega

E no outro vai embora

Cada um de nós...

Fonte: Dados deste estudo.

[3]

[Transcrição da aula 6, 24 de julho de 2020]

LR: Nessa estrofe: Pra ela, pra essa pessoa, tudo isso que ela já passou não é nada![...] Além de tudo que ela passou ainda ficar feliz, venceu as barreiras dificuldades e hoje essa pessoa se sente mais forte.

O nível de compreensão dos alunos sobre a letra da música nos fez refletir sobre como trabalhar temáticas que envolvessem questões voltadas para a vivência dos alunos no Haiti ou no Brasil. Definimos, assim, por acrescentar mais textos que instigassem a produção oral em uma perspectiva mais crítica, já que o conhecimento de vocabulário parecia estar bastante amplo. Para aprimorar o trabalho com estruturas morfossintáticas vinculadas ao uso significativo da língua, ousamos com propostas de aulas que encorajassem o desencadeamento de discussões mais crítico-reflexivas entre os alunos.

Entendemos que o professor precisa ser criativo e ter habilidades para propor aulas abertas, que podem ser reconstruídas no próprio fazer pedagógico, conforme as necessidades que os alunos vão apresentando. Por fim, sabemos que o aprendizado não nasce com o sujeito, ele é construído. E nós, como docentes, também estamos nos construindo e sendo construídos nas nossas experiências como professores ainda durante nossa formação docente.

\section{Considerações finais}

Participar do projeto na modalidade de ensino remoto permitiu que a sensibilidade e compreensão do que é ensinar português em um contexto de acolhi- 
mento fossem ampliadas. Compreendemos que no momento das aulas estávamos entrando na casa de cada aluno e fazendo parte de alguma maneira da vida de cada um deles.

À medida que as aulas foram acontecendo, sentíamos que precisávamos crescer enquanto professores, buscar mais conhecimento e entender como é ser migrante em um país que, muitas vezes, não está preparado para receber uma pessoa de outro território, com línguas e culturas diferentes das presentes no país de acolhimento. Às vezes, o sentimento de insegurança e, com ele, as frustrações, assolavam nossos corações, principalmente após aulas que não saíam como planejado ou em momentos em que os problemas com a internet impossibilitavam não só os alunos, mas também os professores, de se fazerem presentes no GMeet.

Outro ponto que nos chama a atenção é a reciprocidade entre os alunos. Muitos deles assistiram às aulas compartilhando um mesmo aparelho celular com outra pessoa da família, ou com um amigo. Assim, mesmo encontrando dificuldades com o uso dos aparelhos e com os provedores de internet, eles sempre demonstraram interesse e comprometimento com as aulas. Cada um aprendendo no seu tempo e respeitando e ajudando de acordo com nosso alcance.

Os desafios que foram surgindo ao longo do processo contribuíram para uma formação docente em um contexto de ensino de português como língua não materna, para migrantes em situação de vulnerabilidade, especialmente na modalidade remota de ensino. Aprendemos sobre letramento digital, como dar suporte on-line, criar materiais didáticos interativos, lidar com dificuldades dos alunos ante as tecnologias e mediar conflitos culturais em sala de aula.

\section{Referências}

BARBOSA, L. M. A.; SÃO BERNARDO, M. A. de. Português para refugiados: especificidades para acolhimento e inserção. In: SIMÕES, D. M. P.; FIGUEIREDO, F. J. Q. de (org.). Metodologias em/de linguística aplicada para ensino e aprendizagem de línguas. Campinas, SP: Pontes Editores, 2014. p. 269-278.

CROSSLABS. Disponível em: https://crosswordlabs.com/. Acesso em: 20 ago. 2020.

GOOGLE WORKSPACE. Google Classroom. Disponível em: https://classroom.google.com/. Acesso em: 26 jun. 2020.

GOOGLE WORKSPACE. Google Meet. Disponível em: https://meet.google.com/. Acesso em: 17 jun. 2020. 
GOOGLE WORKSPACE. Google Slides Apresentações. Disponível em: https://docs. google.com/presentation/d/11 pp2ac7_e_swiWD4eyCgmVs9eDrHIDdliWoliEpWsiw/edit Acesso em: 17 jun. 2020.

GOOGLE WORKSPACE. Questionários/Formulários Google. Disponível em: https:// docs.google.com/forms/d/1vPnn_r4y-FyEQM77lqfflE1UMbhx0WcnNu3icnmzdaM/ edit. Acesso em: 17 jun. 2020

GROSSO. M. J. Língua de acolhimento, língua de integração. Horizontes de Linguística Aplicada, Belo Horizonte, v. 9, n. 2, p. 61-77, 2010. Disponível em: https:// www.academia.edu/6956350/L\%C3\%ADngua_de_acolhimento_1\%C3\%ADngua_ de_integra\%C3\%A7\%C3\%A3o. Acesso em: 22 jan. 2021.

KRASHEN, S. The Input Hypothesis: issues and implications. 4. ed. New York, Longman, 1985.

QUADRO Europeu Comum de Referência para Línguas (CEFR). Disponível em: https://www.britishcouncil.org.br/quadro-comum-europeu-de-referencia-para-linguas-cefr. Acesso em: 17 jun. 2020.

SANTOS, E. B. dos. Português língua de acolhimento: interação e inserção social de imigrantes por meio do whatsapp. 2018. 138 f. Dissertação (Mestrado em Linguística Aplicada)-Universidade de Brasília, Brasília, 2018. Disponível em: http://bdtd. ibict.br/vufind/Record/UNB_60259b1f829e5ab558abc124f127ea10. Acesso em: 2 abr. 2021.

SÃO BeRnardo, M. A. Português como Língua de Acolhimento: um estudo com imigrantes e pessoas em situação de refúgio no Brasil. 2016. 206 f. Tese (Doutorado) - Universidade Federal de São Carlos, São Carlos, 2016. Disponível em: https://repositorio.ufscar.br/handle/ufscar/8126. Acesso em: 31 out. 2020.

SILVA, S. V. da. Movimentos Migratórios em V: ensino de português para falantes de outras línguas. IFG - Projeto de Ensino-extensão vinculado ao projeto IFG - Saberes Inter/transdisciplinares, cadastrado no câmpus Goiânia, via SUAP, processo n ${ }^{\circ}$ 23373.001757/2020-30. IFG/câmpus Goiânia, 2020.

WORDWALL. Disponível em: https://wordwall.net/pt. Acesso em: 20 out. 2020. 


\section{UMA LICENCIANDA ENSINANDO PORTUGUÊS PARA ESTRANGEIROS: RELATO DE UMA EXPERIÊNCIA DE ENSINO DE PLAc A DISTÂNCIA}

Milena de Oliveira Gomes Liberato Santos da Silva

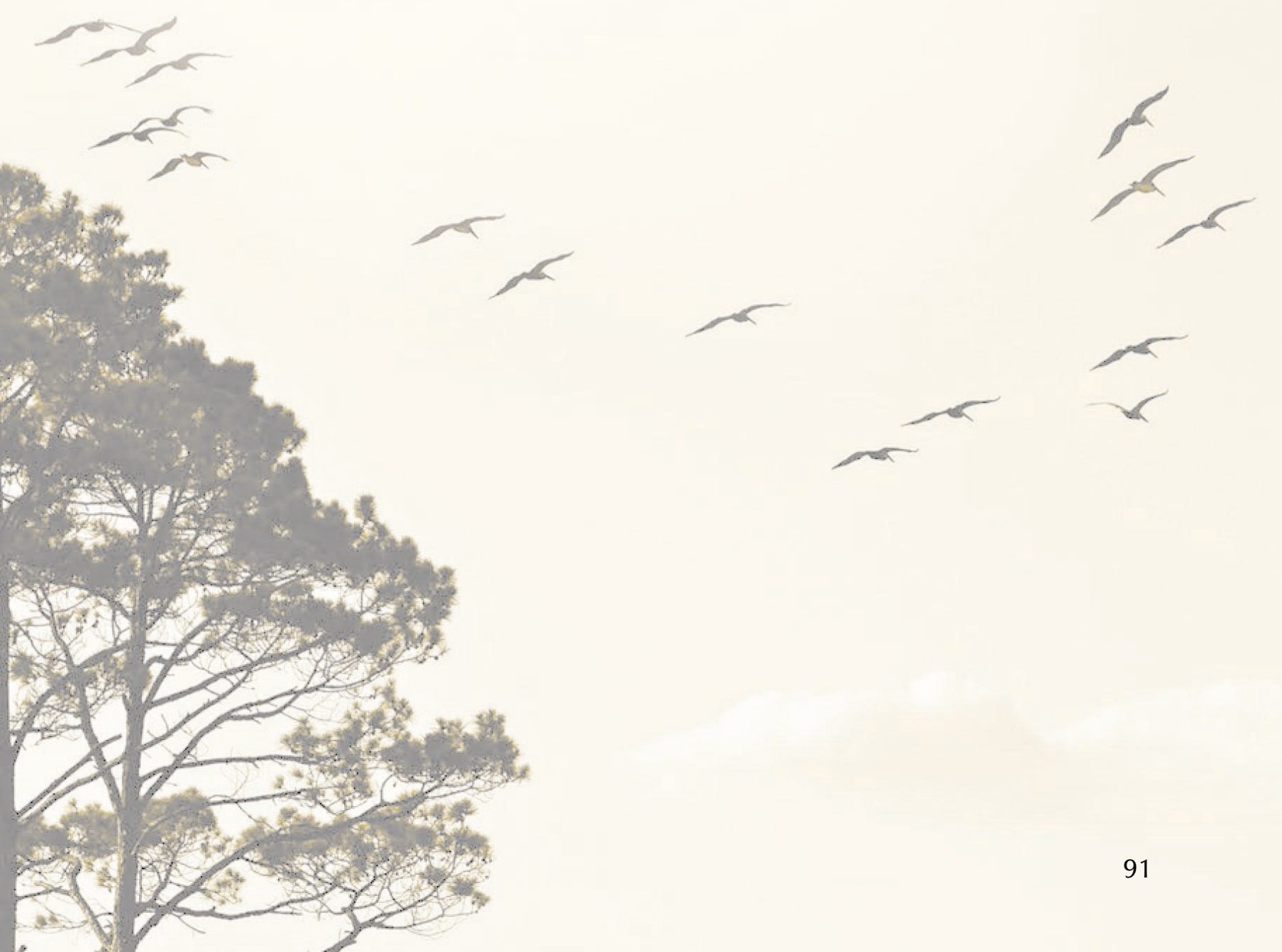


Resumo: Neste relato, uma licenciada em Letras Português descreve sua experiência como professora regente em um curso de PLAc para uma turma de alunos de origem haitiana. A regente comenta como o curso se desenvolveu durante as onze semanas de duração do primeiro módulo e explora os desafios, avanços, aprendizados e resultados obtidos.

Palavras-chave: PLAc. Ensino-aprendizagem de português. Tecnologia Digital. Aprendizes haitianos.

\section{Introdução}

Este texto tem como propósito relatar a experiência de uma integrante da

Eequipe de licenciandos regentes que, orientada por um professor do curso de Letras Português do Instituto Federal de Goiás (IFG), câmpus Goiânia, ministrou aulas para um grupo de alunos haitianos dentro do projeto de ensino e extensão "Movimentos migratórios em V: ensino-aprendizagem de Português para falantes de outras línguas", também conhecido pelo acrônimo MoVe, de Movimentos em V.

$\mathrm{O}$ projeto tem o intuito de ensinar português como língua de acolhimento (PLAc) para imigrantes e refugiados residentes na região metropolitana de Goiânia. Em seus dois anos de existência, o MoVe já atendeu alunos haitianos, jamaicanos e venezuelanos e também acolheu um grupo de alunos indígenas brasileiros, que ainda não haviam sido letrados em língua portuguesa.

Com o tempo e a experiência, a equipe de coordenação geral do projeto passou a formar turmas com alunos que compartilham a mesma língua materna e possuem níveis similares de proficiência em língua portuguesa. Além disso, os licenciandos e seus professores orientadores foram aconselhados a formarem equipes com dois ou mais licenciandos sob a supervisão de um professor, para que eles pudessem compartilhar as responsabilidades de planejamento de aulas, regência, apoio à regência e escolha e elaboração de materiais didáticos. De acordo com essas orientações, a equipe de que trata este relato foi inicialmente formada por quatro licenciandos regentes e um professor orientador do curso de Letras Português do IFG.

\section{Aulas online e questões tecnológicas, financeiras e de letramento}

Até o final do ano de 2019, as aulas de PLAc eram ofertadas presencialmente no câmpus do IFG localizado na região central da cidade de Goiânia, Goiás. Em 2020, porém, o contexto de distanciamento social imposto pela pandemia causada pela Covid-19 obrigou a coordenação geral do projeto a migrar as aulas para o formato online. Dentro deste novo formato, passaram a ser ofertadas duas aulas online semanais, cada uma com 90 minutos de duração. Essas aulas síncronas (em tempo real) são realizadas por meio da ferramenta de videoconferência Google Meet, que 
alunos e professores podem acessar a partir de seus telefones celulares, computadores, tablets ou similares.

Além das aulas síncronas, o projeto prevê que os alunos realizem atividades assíncronas, em seu próprio tempo, utilizando a plataforma Google Classroom, na qual a equipe docente pode postar atividades. Na prática, porém, os alunos desta turma reportaram que o aplicativo WhatsApp, que todos já possuíam em seus celulares, era a única outra tecnologia, além do Google Meet, que eles teriam condições de acessar para se comunicar com os professores. Essa informação dada pelos alunos à equipe docente no início das aulas estava em sintonia com as informações disponíveis no formulário de inscrição para o curso, no qual todos os alunos haitianos desta turma informaram que acessariam as aulas síncronas utilizando seus celulares, já que não tinham acesso a computadores ou tablets.

Esse relato dos alunos revelou três tipos de limitações enfrentadas por eles, a saber: limitações tecnológicas, no caso de alunos que possuíam celulares com tecnologias defasadas e pouca memória de processamento; limitações financeiras, já que cada novo aplicativo instalado em um celular demanda um uso maior do pacote de dados que os alunos têm que comprar para acompanhar as aulas online; e limitações de letramento tecnológico, com alguns alunos se mostrando resistentes a terem que aprender a utilizar tecnologias além das que já estavam acostumados a usar.

\section{Planejamento inicial e verificação do nível de proficiência dos alunos}

Esta equipe docente iniciou as aulas de PLAc para alunos haitianos no dia 14 de julho de 2020. Antes, porém, o primeiro passo tomado foi o de realizar reuniões online para planejar a aula inaugural. A equipe definiu que a melhor estratégia para esse primeiro encontro seria realizar atividades interativas e comunicativas com o objetivo de fazer com que os alunos se sentissem à vontade para participar ativamente dos encontros seguintes. Além disso, havia o interesse dos docentes de utilizar a aula inaugural para verificar o nível de proficiência dos alunos. Essa verificação poderia orientar a equipe na elaboração de conteúdos e atividades e no estabelecimento de metas de aprendizagem compatíveis com o nível de proficiência em língua portuguesa dos alunos.

Incialmente, a equipe docente havia sido informada pela coordenação geral do projeto que a turma seria composta por alunos com nível B1 de proficiência em língua portuguesa, utilizando a nomenclatura de níveis disponibilizada no Quadro Comum Europeu de Referência para Línguas (BRITISH COUNCIL, 2020; CONSELHO DE EUROPA, 2001; VILLAÇA, 2006). É importante ressaltar que o entendimento do termo "nível de proficiência" dentro deste projeto é o de que ao informar, por exemplo, que uma turma é de nível B1, o que se está dizendo é que este é o nível-alvo ou nível de chegada. Em outras palavras, B1 é o nível de proficiência que os alunos atingirão ao concluírem um ou mais módulos de curso dentro do nível indicado. Assim, uma turma nível B1 tem, na realidade, alunos B1 e também alunos nível A2 com 
forte tendência para progredirem para o nível B1 e capacidade de acompanharem os alunos de nível B1.

Ao longo das duas primeiras semanas, porém, ficou evidente que havia uma diferença expressiva no nível de conhecimento da língua portuguesa entre os alunos. Enquanto uma parcela da turma conseguia desenvolver suas ideias em língua portuguesa e executar as atividades propostas, a outra era composta por alunos que, perceptivelmente, tinham muitas dificuldades em acompanhar ou sequer compreender as explicações e o conteúdo.

Orientados pelo professor, os licenciandos regentes começaram a organizar uma divisão dos alunos em dois níveis de proficiência. Essa organização foi realizada de maneira negociada entre os licenciandos, à medida que interagiam com os alunos durante as aulas síncronas e observavam, em tempo real, as respostas orais e escritas dos alunos quanto à riqueza de vocabulário, complexidade sintático-gramatical e pronúncia em língua portuguesa.

A partir da terceira semana de aulas, a equipe conseguiu dividir os alunos em duas turmas, cada uma sob a regência de dois licenciandos. Dois regentes passaram a trabalhar com uma turma de nível A2 (iniciantes) com quatro alunos; e os outros dois ficaram responsáveis pelo trabalho com uma turma de nível B1 (intermediário) com cinco alunos. Essa divisão não interferiu no formato das aulas, que mantiveram a mesma duração e continuaram sendo ministradas nos mesmos dias e horários estabelecidos no início do curso. O professor orientador, no entanto, passou a ter que observar e monitorar as duas turmas simultaneamente, em sua função de supervisão e apoio às aulas síncronas.

Em decorrência dessa divisão, obtivemos uma relevante otimização do ensino. Com duas turmas e tendo alunos em número reduzido em relação à turma original, os regentes conseguiram identificar melhor as dificuldades de cada aluno e trabalhá-las a cada novo encontro com as atividades específicas que desenvolviam.

Neste relato, será dado destaque para a turma B1, visto que a coautora esteve à frente desta turma e pôde acompanhar de perto os desafios e avanços desse grupo de alunos. Ela faz, também, uma reflexão sobre sua própria evolução na posição de professora regente do projeto.

\section{Evolução dos planos de aula}

As aulas decorreram com constantes ajustes, com a regente sempre buscando aperfeiçoar suas práticas de ensino. No início do módulo, o professor orientador solicitou que os licenciandos elaborassem planos de aula utilizando um modelo com o qual já estivessem habituados. Apesar de conseguirem atender o propósito geral, os planos inicialmente utilizados pelos licenciandos eram muito sintetizados e pouco estruturados (ver Apêndice A). Com o avanço das aulas e o conhecimento prático adquirido com o auxílio do professor orientador, os licenciandos conseguiram reestrutu- 
rar os planos de aula, tornando-os mais precisos e completos. Sobretudo, foi possível segmentar a forma como os conteúdos seriam trabalhados em cada turma, adequando-os aos níveis iniciante e intermediário.

Em sua segunda versão (ver Apêndice B), os planos de aula também sofreram alterações relacionadas aos seus elementos constitutivos, que passaram a ser divididos em seis seções: (1) Tema, na qual é listado o conteúdo a ser trabalhado na aula; (2) Referência, com informações bibliográficas de livros didáticos e outros materiais de ensino utilizados; (3) Objetivos, indicando o que os licenciandos esperam alcançar com a aula; (4) Justificativa, seção na qual é explicada a relevância do conteúdo selecionado para o aprendizado dos alunos; (5) Recursos didáticos, com a descrição dos instrumentos que os licenciandos desejam utilizar para ministrarem as aulas; e (6) Procedimento, com o detalhamento e a sequência das ações de ensino previstas para a aula.

A construção do plano de aula, conforme descrito acima, foi essencial para nortear e facilitar o avanço dos licenciandos dentro do projeto. Comparando o plano de aula inicial com sua segunda versão, é perceptível a evolução principalmente nos quesitos relativos à estrutura e à didática (ver Apêndices 1 e 2). A modificação no plano de aula também conferiu maior clareza à instrução dos conteúdos ministrados em sala de aula, direcionando o foco dos licenciandos para trabalhar as habilidades comunicativas dos alunos. Levando isso em consideração, os licenciandos priorizaram elaborar atividades em que os alunos participassem de forma ativa e dinâmica, dialogando com os colegas e com os professores regentes.

\section{Atividades comunicativas}

Dentre as atividades realizadas que objetivaram colocar em prática o ensino comunicativo de línguas, é possível destacar: o trabalho com diálogos do dia a dia; a apresentação de seminários; a realização de atividades explanativas e demonstrativas, como na ocasião em que foi proposto, como atividade para casa, que os alunos gravassem um vídeo preparando uma comida típica do seu país de origem e descrevessem os ingredientes da receita e todo o processo de preparo.

Outra atividade prática, que vale ressaltar, foi a aula de Língua Brasileira de Sinais (Libras). Esse tema estava proposto no material didático dos alunos, porém era abordado de forma breve e concisa. A licencianda, coautora deste artigo, decidiu dedicar um tempo maior da aula para trabalhar este tema, buscando salientar aos alunos a importância da inclusão social, já que Libras é a segunda língua oficial do Brasil. Ademais, havia o entendimento de que abordar esse tema poderia gerar uma aula prática, dinâmica e bastante instrutiva.

Para a realização da aula de Libras, foi convidada uma colega licencianda em Letras que é capacitada pelo Curso de Libras para Ouvintes oferecido pelo Centro de 
Capacitação de Profissionais da Educação e de Atendimento às Pessoas com Surdez (CAS), da Secretaria de Estado da Educação do Governo de Goiás (CAS, 2020). Durante a aula os alunos haitianos aprenderam o conceito de Libras, o alfabeto manual e alguns cumprimentos usuais. Durante toda a aula foi solicitado aos alunos que repetissem os sinais. A princípio, eles se mostraram inibidos e estranharam a linguagem pelo fato de a comunicação ser realizada apenas pelo uso das mãos. Porém, com os estímulos adequados, eles logo perderam a timidez e participaram ativamente da aula, declarando, ao final, que a acharam muito interessante e divertida.

\section{Material didático, recursos tecnológicos e desafios}

O principal material de apoio utilizado nas onze semanas de curso foi o livro didático Pode Entrar (FEITOSA et al., 2015), que foi entregue a cada um dos alunos em versão impressa para que eles pudessem acompanhar o conteúdo enquanto assistiam às aulas síncronas usando seus celulares. Entretanto, em alguns casos, o conteúdo do livro para a turma B1 não estava compatível com o nível de proficiência dos alunos. Sendo assim, em alguns casos fizemos adaptações nos exercícios para calibrar o nível de dificuldade, ou então elaboramos atividades complementares.

A incompatibilidade de algumas atividades do livro didático com o nível de proficiência dos alunos foi um dos desafios que enfrentamos nos dois meses e meio de trabalho no projeto. Algumas dificuldades tecnológicas também se apresentaram, dada a necessidade de oferecer o curso na modalidade de ensino a distância como alternativa de ensino possível em meio à pandemia da Covid-19. Alguns alunos, porém, não possuíam letramento adequado para realizar aulas a distância e, por isso, foi necessário ensiná-los a usar os recursos da ferramenta Google Meet. Por exemplo, tivemos que os ensinar a ativar e desativar a câmera e o microfone e a utilizar o chat (bate-papo) da ferramenta.

Outra dificuldade que tivemos que contornar foi a falta de recursos financeiros dos alunos para adquirir pacotes de dados e manter a internet móvel em seus apareIhos telefônicos. Como consequência, alguns alunos faltavam às aulas síncronas e outros acessavam a sala no Google Meet, mas logo eram desconectados. Sensibilizada com a história, uma aluna da instituição, que atua como voluntária em projetos sociais, mobilizou colegas voluntários e conseguiu arrecadar uma modesta quantia em dinheiro para comprar pequenas quantidades de créditos para os alunos conseguirem seguir participando do curso.

Houve desafios também para os licenciandos regentes que, em alguns momentos, sofreram bloqueio criativo e não conseguiam planejar aulas que eles considerassem comunicativas, relevantes e pertinentes aos alunos. A equipe também precisou se familiarizar com os recursos tecnológicos necessários para ministrar aulas a distância e com outros recursos para desenvolver aulas mais interessantes e dinâmicas. 


\section{Trabalho em equipe e primeiros passos na formação docente}

O projeto 'Movimentos Migratórios em V' foi, para a licencianda coautora deste artigo, a primeira oportunidade de entrada na docência. Dentro dessa experiência, destaca-se a sua percepção quanto à importância do trabalho em equipe.

Uma questão importante nesse quesito foi o apoio do professor orientador que, durante todo o processo, esteve sempre pronto para auxiliar os regentes no planejamento, na supervisão das aulas síncronas, na resolução de problemas técnicos e no apoio aos licenciandos a todo momento. Além disso, o orientador fez revisões construtivas nos planos de aula e materiais didáticos utilizados nas aulas.

Durante onze semanas de ensino a distância, a equipe de licenciandos se manteve conectada por meio de reuniões semanais síncronas pré e pós-aula realizadas pelo Google Meet, nas quais todos contribuíam trocando ideias, compartilhando experiências de erros e acertos em cada turma e aula, pontuando os exercícios em que os alunos deram um bom retorno e realizando revisões dos planos de aulas uns dos outros. Uma das aprendizagens foi a de que em uma equipe de professores em que há trabalho coletivo, é possível desenvolver aulas mais interessantes e mais bem elaboradas. Trabalhando juntos, os membros da equipe superaram desafios, contornaram imprevistos e alcançaram os objetivos traçados.

\section{MoVirtual: Seminário de Experiências Docentes}

O primeiro módulo do curso foi finalizado com a realização do I Seminário Movimentos Migratórios em V: experiências com o ensino aprendizagem de português para falantes de outras línguas - MoVirtual I. O evento tinha como objetivo proporcionar a licenciandos regentes e professores orientadores um espaço para relatarem suas experiências durante o projeto.

O seminário contou com a participação de diversos convidados que dialogaram sobre o ensino de língua estrangeira e, mais especificamente, PLAc. Os alunos do curso de PLAc também foram convidados a participar, seja como ouvintes ou palestrantes. Eles ficaram muito honrados com o convite e demonstraram grande comprometimento e apreço em participar do evento e serem professores por um dia.

Para que tivessem um bom desempenho na palestra e na oficina que ministrariam no I MoVirtual, os alunos haitianos participaram de ensaios supervisionados pelos licenciandos das turmas B1 e A2 durante as duas semanas que antecederam o evento, sendo auxiliados na produção e apresentação do conteúdo. Trabalharam arduamente e entregaram uma palestra bem-organizada e emocionante, além de realizarem uma oficina interessante e divertida.

Na palestra intitulada Conhecendo o Haiti: País, Povo e Cultura (ver Figura 1), alguns alunos da turma B1, que aceitaram o convite para serem palestrantes, discorreram sobre a história do Haiti, lugares turísticos, política e ritmos de dança. 
Figura 1. Slide da palestra Conhecendo o Haiti: País, Povo e Cultura

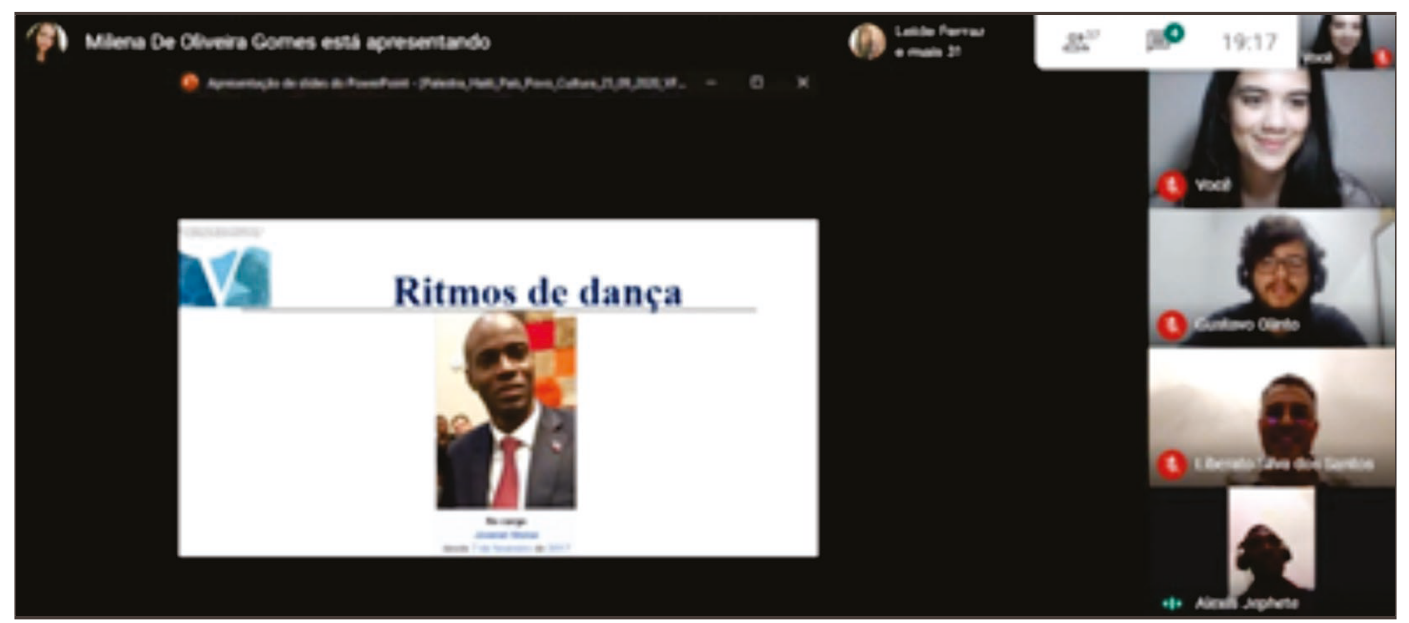

Fonte: Banco de dados do projeto MoVe.

Ainda dentro do I MoVirtual, alguns alunos da turma B1 ministraram uma oficina nomeada Oficina de Crioulo: Aprenda e pratique frases básicas em crioulo haitiano (ver Figura 2), na qual ensinaram aos participantes brasileiros os pronomes pessoais e algumas contrações e frases básicas na língua haitiana.

Figura 2. Oficina de crioulo haitiano no evento I MoVirtual

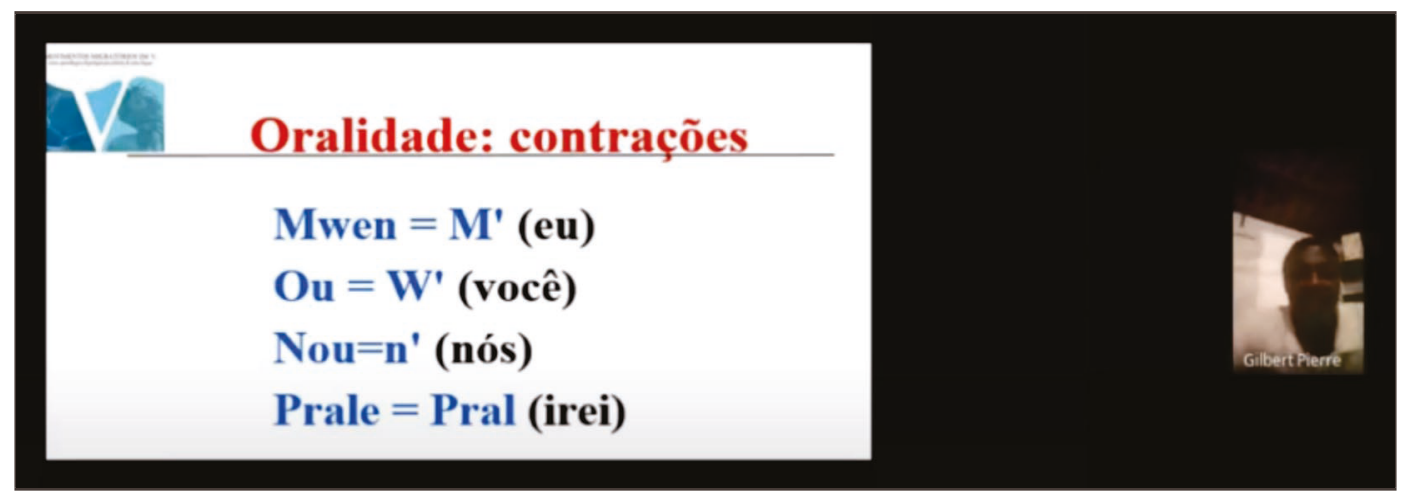

Fonte: Banco de dados do projeto MoVe.

Durante a explanação dos alunos, ficaram perceptíveis o patriotismo e a paixão que eles sentem por seu país de origem. Os regentes já haviam sentido isso no início do curso quando, por sugestão do orientador, abriram espaço nas aulas para que os alunos trocassem de lugar com os licenciandos e ensinassem algumas palavras e frases em sua língua materna. Foi como a inclusão da língua e cultura do país de origem no planejamento das aulas teve um poder motivacional extraordinário para os alunos se manterem comprometidos com a continuidade de sua aprendizagem de português e sua permanência no projeto. 


\section{Considerações finais}

Ficou evidente, para os licenciandos regentes, o cuidado que é preciso ter ao trabalhar o PLAc para imigrantes e refugiados. Ensinar uma língua envolve falar sobre os aspectos culturais e sociais em que essa língua está contextualizada. Caso contrário, corre-se o risco de sobrepor ou, ainda, anular a cultura de origem dos alunos migrantes e refugiados. $\mathrm{O}$ acolhimento, portanto, deve abranger vários aspectos e não somente o linguístico.

Concluindo, o Projeto Movimentos Migratórios em V forneceu aos licenciandos uma grande bagagem teórica e prática, contribuindo com sua formação como professores de português para estrangeiros. Da mesma forma, a licencianda coautora deste artigo espera estar fazendo diferença na vida de seus alunos, acolhendo-os, auxiliando-os e facilitando sua transição de vida e sua morada em um país estrangeiro.

\section{Referências}

BRITISH COUNCIL. Resumo do Quadro Comum Europeu de Referência para Línguas. São Paulo: British Council, 2020. Disponível em: https://www.britishcouncil.org.br/quadro-comum-europeu-de-referencia-para-linguas-cefr. Acesso em: 7 jul. 2020.

CAS. Curso de LIBRAS para ouvintes. Centro de Capacitação de Profissionais da Educação e de Atendimento às Pessoas com Surdez (CAS). Goiânia: Secretaria de Estado da Educação do Governo de Goiás, 2020. Disponível em: https://casgoiania.blogspot. com/p/nossos-cursos.html. Acesso em: 11 ago. 2020.

CONSELHO DE EUROPA. Quadro europeu comum de referência para as línguas: aprendizagem, ensino, avaliação. Porto: Edições ASA, 2001. Disponível em: http:// www.dge.mec.pt/sites/default/files/Basico/Documentos/quadro_europeu_comum_ referencia.pdf. Acesso em: 7 jul. 2020.

FEITOSA, J.; MARRA, J.; FASSON, K.; MOREIRA, N.; PEREIRA, R.; AMARO, T. Pode entrar: português do Brasil para refugiadas e refugiados. 1. ed. São Paulo: Edição dos autores, 2015. Disponível em: https://www.acnur.org/portugues/wp-content/uploads/2018/02/Pode_Entrar_ACNUR-2015.pdf. Acesso em: 7 jul. 2020.

VILAÇA, M. L. C. Conhecendo o quadro comum europeu de referência para línguas: fundamentos, objetivos e aplicações. Revista Eletrônica do Instituto de Humanidades da Unigranrio, Universidade Federal Fluminense, Rio de Janeiro, v. 5, n. 17, abr./jun. 2006. 


\section{APÊNDICES}

\section{Apêndice A - Formato e conteúdo da primeira versão do plano de aula}

Plano para a Aula 06 - Data: 31/07/2020 - Horário: 19h às 20h30 (1h30)

Alunos e Alunas da Turma: Acolher B1-B2

Equipe docente e discente escalada para esta aula:

\begin{tabular}{|l|l|}
\hline $\begin{array}{l}\text { Licenciandos regentes: Shirley Dias (IFG), Gustavo Olinto (IFG) e Milena Gomes (IFG) } \\
\text { Licencianda regente de apoio: Bruna Araújo (IFG) } \\
\text { Professor orientador: Liberato Santos (IFG) }\end{array}$ \\
\hline Remas & Revisão unidades 1, 2 e 3 \\
\hline Referência & $\begin{array}{l}\text { Capítulos 1, 2 e 3 do livro Pode Entrar: Português do Brasil para Refugia- } \\
\text { das e Refugiados. São Paulo: Edição dos Autores, 2015. } \\
\text { Link para acessar a referência, caso esteja disponível: } \\
\text { https://www.acnur.org/portugues/wp-content/uploads/2018/02/Pode_En- } \\
\text { trar_ACNUR-2015.pdf }\end{array}$ \\
\hline \multirow{5}{*}{ Conteúdo } & $\begin{array}{l}\text { Alunos B1-B2 } \\
\text { Pronomes pessoais (p. 12) } \\
\text { Adjetivos possessivos (p. 12) } \\
\text { Adjetivos pessoais (p. 19) } \\
\text { Pronomes interrogativos (p. 21) } \\
\text { Alunos A1-A2 } \\
\text { Alfabeto } \\
\text { Números e contas em português (p. 10) } \\
\text { Nacionalidades e bandeiras (p. 17) } \\
\text { Objetos comuns em casa e na sala de aula (p. 25) } \\
\text { Conjugação de verbos (p. 30) }\end{array}$ \\
\hline $\begin{array}{l}\text { Alunos e Alunas B1-B2 } \\
\text { Saber utilizar na comunicação escrita e oral: pronomes pessoais, adjetivos } \\
\text { possessivos, adjetivos pessoais e pronomes interrogativos. }\end{array}$ \\
$\begin{array}{l}\text { Alunos e Alunas A1-A2 } \\
\text { Dialogar com uma pessoa e responder sobre coisas básicas relacionadas } \\
\text { a si mesmo. } \\
\text { Tornar os alunos aptos a utilizar o alfabeto romano e os números na lín- } \\
\text { gua portuguesa. Também irão aprender a conversar e escrever sobre pa- } \\
\text { íses, nacionalidades, objetos de uso pessoal (escolar e doméstico) utili- } \\
\text { zando artigos definidos e indefinidos; e conjugar verbos para facilitar a } \\
\text { comunicação. }\end{array}$ \\
\hline \multirow{5}{*}{ Objetivos }
\end{tabular}




\begin{tabular}{|c|c|}
\hline Justificativa & $\begin{array}{l}\text { Alunos e Alunas (B1-B2) } \\
\text { Durante a reunião dos regentes com o orientador foi notada a necessi- } \\
\text { dade de realizar uma revisão com os alunos, com o objetivo de consta- } \\
\text { tar se houve êxito no aprendizado quanto ao conteúdo trabalhado até o } \\
\text { momento. } \\
\text { Alunos e Alunas (A1-A2) } \\
\text { Durante a reunião dos regentes com o orientador foi notada a necessida- } \\
\text { de de realizar uma revisão com os alunos, com o objetivo de constatar } \\
\text { se houve êxito no aprendizado quanto ao conteúdo trabalhado até o mo- } \\
\text { mento. }\end{array}$ \\
\hline $\begin{array}{l}\text { Recursos } \\
\text { Didáticos }\end{array}$ & $\begin{array}{l}\text { - Aula online síncrona pelo aplicativo Google Meet } \\
\text { - Cópia impressa das atividades do capítulo } 3 \text { do livro Pode Entrar, para } \\
\text { alunos/as que têm e preferem usar o livro impresso. } \\
\text { - Cópia digital (em Word ou PDF) das atividades do capítulo } 3 \text { para alu- } \\
\text { nos/as que preferem usar materiais em formato digital. } \\
\text { - Apresentação de slides em PowerPoint via Google Meet. } \\
\text { - Computadores para regentes e orientador acessarem e gerenciarem a au- } \\
\text { la online no Google Meet. } \\
\text { - Celulares para alunos e regentes se comunicarem via Google Meet e } \\
\text { acessarem materiais no Google Classroom. } \\
\text { - Pasta no Google Drive com materiais didáticos em formato digital. } \\
\text { - Atividades postadas em sala online no Google Classroom. }\end{array}$ \\
\hline Procedimentos & $\begin{array}{l}\text { (1) Aguardar a entrada das alunas e alunos na sala de aula online (5 min). } \\
\text { (2-B1-B2) Solicitar aos alunos que compartilhem a resposta da atividade } \\
\text { de casa (Google Classroom) (10 min). } \\
\text { (3-B1-B2) Dar exemplos e depois explicar o tema Pronomes Pessoais (p. } \\
\text { 12) (10 min). } \\
\text { (4-B1-B2) Pedir para realizarem a atividade proposta sobre o tema Prono- } \\
\text { mes Pessoais (p. 13) (5 min.). } \\
\text { (5-B1-B2) Dar exemplos e explicar o tema Pronomes Interrogativos (p. 21) } \\
\text { (10 min). } \\
\text { (6-B1-B2) Pedir para realizar a atividade proposta sobre o tema Pronome } \\
\text { Interrogativo (5 min). } \\
\text { (7-B1-B2) Dar exemplos e explicar o tema Adjetivos Pessoais (p. 19) (10 } \\
\text { min). } \\
\text { (8-B1-B2) Pedir para realizar a atividade proposta sobre o tema Adjetivo } \\
\text { Pessoais (p. 19) (5 min). } \\
\text { (9-B1-B2) Dar exemplos e explicar o tema Adjetivos Possessivos (p. 12) } \\
\text { (10 min). } \\
\text { (10-B1-B2) Pedir para realizar a atividade proposta sobre o tema (p. 12) } \\
\text { (5 min). } \\
\text { (2-A1-A2) Apresentar em slide o alfabeto romano (p. 9) (5 min). } \\
\text { (3-A1-A2) Apresentar em slide um diálogo para que cada aluno leia e } \\
\text { complete sentenças, interpretando um papel (p. 9) (10 min). }\end{array}$ \\
\hline
\end{tabular}




\begin{tabular}{|l|l|}
\hline (4-A1-A2) Ensinar a contar os números de 1 a 100 e praticar matemática, fa- \\
zendo contas de adição, subtração, multiplicação e divisão (p. 10) (20 min). \\
(5-A1-A2) Apresentar exemplos de diálogos como os presentes na ativida- \\
de 2.1 do livro didático, e aplicar uma atividade em uma apresentação de \\
slide referente a este conteúdo (p. 9) (15 min). \\
(6-A1-A2) Apresentar em slide bandeiras de países e seus respectivos no- \\
mes para praticar a oralidade (p. 17) (5 min). \\
(7-A1-A2) Reapresentar as bandeiras, desta vez sem seus nomes, para pra- \\
ticar a fala e reforçar o aprendizado (p. 17) (10 min). \\
(8-A1-A2) Apresentar em slide a imagem de cada objeto junto da palavra \\
que o representa e repetir com os alunos as suas pronúncias (p. 25 e 28) \\
(10 min). \\
(8-A1-A2) Apresentar em slide verbos e conjugar juntamente dos discen- \\
tes os verbos: ter, ver, perder, buscar, encontrar, vir, ser, estar, ir, vir, gos- \\
tar (p. 30) (10 min).
\end{tabular}

Apêndice B - Formato e conteúdo da versão revisada e melhorada do plano de aula

Plano para a Aula 18 - Data: 11/09/2020 - Horário: 19h às 20h30 (1h30)

Aprendizes de PLAc das Turmas: Acolher A2 e Acolher B1

Equipe escalada para esta aula:

\begin{tabular}{|c|c|c|}
\hline \multicolumn{2}{|c|}{$\begin{array}{l}\text { Licencianda(o)(s) regentes, turma Acolher A2 Gustavo } \\
\text { Olinto (IFG) } \\
\text { Apoio: Prof. Liberato Santos (IFG) }\end{array}$} & $\begin{array}{l}\text { Licencianda(o)s regentes, turma } \\
\text { Acolher B1 Milena Gomes (IFG) } \\
\text { Apoio: Prof. Liberato Santos (IFG) }\end{array}$ \\
\hline \multicolumn{3}{|c|}{ Orientador(a): Prof. Liberato Santos (IFG) } \\
\hline $\begin{array}{l}\text { Temas } \\
\text { (Conteúdo) }\end{array}$ & $\begin{array}{l}\text { Turma Acolher A2 } \\
\text { - Verbos reflexivos (p. 70) } \\
\text { - Revisão sobre } \\
\text { *advérbios de intensidade (p. 77) } \\
\text { *Advérbios de tempo (p. 69) } \\
\text { * Adjetivos possessivos (p. 12) } \\
\text { *Pronomes possessivos (p. 45) } \\
\text { *Pronomes oblíquos (p. 37) }\end{array}$ & $\begin{array}{l}\text { Turma Acolher B1 } \\
\text { - Direitos Humanos } \\
\text { - Família } \\
\text { - Revisão sobre: } \\
\text { *Apresentação Pessoal }\end{array}$ \\
\hline Referência & $\begin{array}{l}\text { Turma Acolher A2 } \\
\text { Capítulos } 9 \text { e } 10 \text { do livro Pode } \\
\text { Entrar: Português do Brasil pa- } \\
\text { ra Refugiadas e Refugiados. São } \\
\text { Paulo: Edição dos Autores, } 2015 .\end{array}$ & $\begin{array}{l}\text { Turma Acolher B1 } \\
\text { Capítulos } 1 \text { e } 12 \text { do livro Pode } \\
\text { Entrar: Português do Brasil pa- } \\
\text { ra Refugiadas e Refugiados. São } \\
\text { Paulo: Edição dos Autores, } 2015 .\end{array}$ \\
\hline
\end{tabular}




\begin{tabular}{|c|c|c|}
\hline Referência & $\begin{array}{l}\text { Link para acessar a referência, ca- } \\
\text { so esteja disponível: } \\
\text { https://www.acnur.org/por- } \\
\text { tugues/wp-content/uploa- } \\
\text { ds/2018/02/Pode_Entrar_AC- } \\
\text { NUR-2015.pdf }\end{array}$ & $\begin{array}{l}\text { Link para acessar a referência, ca- } \\
\text { so esteja disponível: } \\
\text { https://www.acnur.org/por- } \\
\text { tugues/wp-content/uploa- } \\
\text { ds/2018/02/Pode_Entrar_AC- } \\
\text { NUR-2015.pdf } \\
\text { Unicef: Declaração Universal } \\
\text { dos Direitos Humanos } \\
\text { Link: https://tinyurl.com/ } \\
\text { yyfw57ln }\end{array}$ \\
\hline $\begin{array}{l}\text { Objetivos } \\
\text { - Comunicativos; e } \\
\text { - de Aprendizagem: } \\
\text { Ao final desta aula, } \\
\text { os/as aprendizes de- } \\
\text { verão ser capazes } \\
\text { de... }\end{array}$ & $\begin{array}{l}\text { Turma Acolher A2 } \\
\text { Ao final desta aula, os/as apren- } \\
\text { dizes deverão ser capazes de: } \\
\text { (1) falar e escrever sobre... } \\
\text { - Si mesmos e a comunidade em } \\
\text { que estão inseridos } \\
\text { (2) utilizar os seguintes recursos } \\
\text { linguísticos: } \\
\text { - Verbos reflexivos } \\
\text { - Advérbios de tempo e de inten- } \\
\text { sidade } \\
\text { - Adjetivos possessivos } \\
\text { - Pronomes possessivos } \\
\text { - Pronomes oblíquos }\end{array}$ & $\begin{array}{l}\text { Turma Acolher B1 } \\
\text { Ao final desta aula, os/as apren- } \\
\text { dizes deverão ser capazes de: } \\
\text { (1) falar e escrever... } \\
\text {-se apresentando } \\
\text {-sobre os direitos humanos } \\
\text { - membros da família } \\
\text { (2) utilizar os seguintes recursos } \\
\text { linguísticos: }\end{array}$ \\
\hline Justificativa & $\begin{array}{l}\text { Turma Acolher A2 } \\
\text { Percebemos nas aulas anteriores } \\
\text { que os/as aprendizes estão neces- } \\
\text { sitando aprender: } \\
\text { - Pronunciação } \\
\text { Para auxiliá-los neste sentido, ire- } \\
\text { mos realizar as seguintes ações: } \\
\text { - Trabalhar conteúdo de cunho } \\
\text { gramatical para dar base a con- } \\
\text { versações futuras em seus coti- } \\
\text { dianos pessoais e a aulas futuras } \\
\text { com temas voltados à pronúncia. }\end{array}$ & $\begin{array}{l}\text { Turma Acolher B1 } \\
\text { *Apesar de terem nível de profi- } \\
\text { ciência B1, percebemos, nas au- } \\
\text { las anteriores, que os/as aprendi- } \\
\text { zes estão necessitando aprender: } \\
\text { - Como se apresentar } \\
\text { - Direitos humanos que possuem } \\
\text { - Membros da família } \\
\text { Para auxiliá-los neste sentido, ire- } \\
\text { mos realizar as seguintes ações: } \\
\text { - Exemplificar como se apresentar } \\
\text { - Listar os direitos humanos } \\
\text { - Apresentar o vocabulário de } \\
\text { membros da família }\end{array}$ \\
\hline
\end{tabular}




\begin{tabular}{|c|c|c|}
\hline $\begin{array}{l}\text { Recursos } \\
\text { Didáticos }\end{array}$ & $\begin{array}{l}\text { Turma Acolher A2 } \\
\text { - Google Meet (GM) p/ aula sín- } \\
\text { crona. } \\
\text { - Cópia impressa do livro Pode } \\
\text { Entrar. } \\
\text { - Cópia digital (Word ou PDF) do } \\
\text { livro. } \\
\text { - PowerPoint (slides para orientar } \\
\text { aula). } \\
\text { - Computadores e celulares para } \\
\text { regentes e orientador gerencia- } \\
\text { rem a aula no GM. } \\
\text { - Celulares para alunos interagi- } \\
\text { rem com regentes e orientador } \\
\text { no GM. } \\
\text { - Google Drive com materiais di- } \\
\text { dáticos. }\end{array}$ & $\begin{array}{l}\text { Turma Acolher B1 } \\
\text { - Google Meet (GM) p/ aula sín- } \\
\text { crona. } \\
\text { - Cópia impressa do livro Pode } \\
\text { Entrar. } \\
\text { - Cópia digital (Word ou PDF) do } \\
\text { livro. } \\
\text { - PowerPoint (slides para orientar } \\
\text { aula). } \\
\text { - Computadores e celulares para } \\
\text { regentes e orientador gerencia- } \\
\text { rem a aula no GM. } \\
\text { - Celulares para alunos interagi- } \\
\text { rem com regentes e orientador } \\
\text { no GM. } \\
\text { - Google Drive com materiais di- } \\
\text { dáticos. }\end{array}$ \\
\hline $\begin{array}{l}\text { Procedimentos } \\
\text { (dos Regentes) }\end{array}$ & $\begin{array}{l}\text { Turma Acolher A2 } \\
\text { OBS.: os tempos indicados em } \\
\text { parênteses são tempos aproxima- } \\
\text { dos. } \\
\text { Procedimento (1): } \\
\text { Abertura } \\
\text { (1) Aguardar a entrada dos/das } \\
\text { aprendizes no Word (5 min) } \\
\text { Procedimento (2): } \\
\text { Aquisição e/ou Consolidação } \\
\text { Orientar as/os aprendizes para } \\
\text { que realizem as atividades indi- } \\
\text { cadas a seguir: } \\
\text { 1. Receber e conversar sobre a } \\
\text { atividade sobre verbos no pre- } \\
\text { sente do indicativo (p. 13, 14), } \\
\text { futuro do presente (p. } 77,78) \text { e } \\
\text { pretérito perfeito (p. } 61 \text { ), que foi } \\
\text { passada para casa na última au- } \\
\text { la. (10 min) } \\
\text { 2. Explicar e apresentar verbos re- } \\
\text { flexivos (p. } 70 \text { ) (5 min) }\end{array}$ & $\begin{array}{l}\text { Turma Acolher B1 } \\
\text { OBS.: os tempos indicados em } \\
\text { parênteses são tempos aproxima- } \\
\text { dos. } \\
\text { Procedimento (1): } \\
\text { Abertura } \\
\text { (1) Aguardar a entrada dos/das } \\
\text { aprendizes no Word (5 min) } \\
\text { Procedimento (2): Aquisição } \\
+ \\
\text { Procedimento (3): Consolidação } \\
\text { Orientar as/os aprendizes para } \\
\text { que realizem as atividades indi- } \\
\text { cadas a seguir: } \\
\text { 1. Retomar a discussão com as } \\
\text { questões sobre o tema "Direitos } \\
\text { Humanos" (anexadas abaixo) S.3- } \\
\text { 4 (10min) } \\
\text { 2. Apresentar alguns direitos hu- } \\
\text { manos aos alunos S.5-9 (5min) }\end{array}$ \\
\hline
\end{tabular}




\begin{tabular}{|c|c|c|}
\hline $\begin{array}{l}\text { Procedimentos } \\
\text { (dos Regentes) }\end{array}$ & $\begin{array}{l}\text { 3. Praticar conjugação de verbos } \\
\text { reflexivos pedindo para as alu- } \\
\text { nas conjugarem um verbo refle- } \\
\text { xivo no presente do indicativo. (5 } \\
\text { min) } \\
\text { 4. Revisão: mostrar novamente os } \\
\text { advérbios de intensidade e con- } \\
\text { versar com as alunas sobre eles; } \\
\text { pedindo para que utilizem esses } \\
\text { advérbios em algumas frases que } \\
\text { estão disponíveis no slide. (p. } 77 \text { ) } \\
\text { (10 min) } \\
\text { 5. Apresentar e explicar os advér- } \\
\text { bios de tempo (p. } 69 \text { ) (10 min) } \\
\text { 6. Pedir para as alunas que fa- } \\
\text { çam a atividade sobre advérbios } \\
\text { de tempo presente no tópico "8.7 } \\
\text { Gramática" da página } 69 \text { do livro } \\
\text { didático e auxiliá-las com o que } \\
\text { for necessário (10 min). } \\
\text { 7. Apresentar, conversar e expli- } \\
\text { car sobre adjetivos possessivos } \\
\text { (p. 12) (5 min). } \\
\text { 8. Apresentar, conversar e expli- } \\
\text { car sobre pronomes possessivos } \\
\text { (p. } 45 \text { ) (5 min). } \\
\text { 9. Apresentar em slides ativida- } \\
\text { de sobre pronomes possessivos } \\
\text { (5 min). }\end{array}$ & $\begin{array}{l}\text { 3. Solicitar a leitura do texto } \\
12.4 \text { p. } 99 \text { ( } 10 \text { min) } \\
\text { 4. Apresentar as diferentes for- } \\
\text { mas de famílias } \mathrm{S} .12-18 \text { ( } 5 \mathrm{~min}) \\
\text { 5. Explicar aos alunos sobre ca- } \\
\text { ça-palavras tema "Família" S.11- } \\
18 \text { (5min) } \\
\text { 6. Pedir aos alunos para encon- } \\
\text { trarem as palavras no caça-pa- } \\
\text { lavras do tema "Família" S.19 } \\
\text { (5min) } \\
\text { 7. Pedir para que respondam à } \\
\text { questão sobre o tema "Família" } \\
\text { p. } 99 \text { (10min) } \\
\text { 8. Solicitar aos alunos a leitura } \\
\text { do diálogo } 1.1 \text { p. } 9 \text { (5min) } \\
\text { 9. Pedir que os alunos se apre- } \\
\text { sentem uns para os outros S. } 23 \\
\text { (5min) } \\
\text { 10.Apresentar aos alunos cum- } \\
\text { primentos p. } 10 \text { (5min) } \\
\text { 11.Pedir aos alunos que treinem } \\
\text { com os colegas o uso do vocabu- } \\
\text { lário aprendido no procedimento } \\
\text { anterior (5min). }\end{array}$ \\
\hline
\end{tabular}




\title{
MEDIAÇÃO NO PLAc COMO ESTRATÉGIA DE ENSINO DE PORTUGUÊS BRASILEIRO PARA HAITIANOS: UM INTERCÂMBIO CULTURAL
}

\author{
Clara Oliveira Campos \\ Ana Cristina de Moura dos Santos \\ Cleide Araújo Machado
}

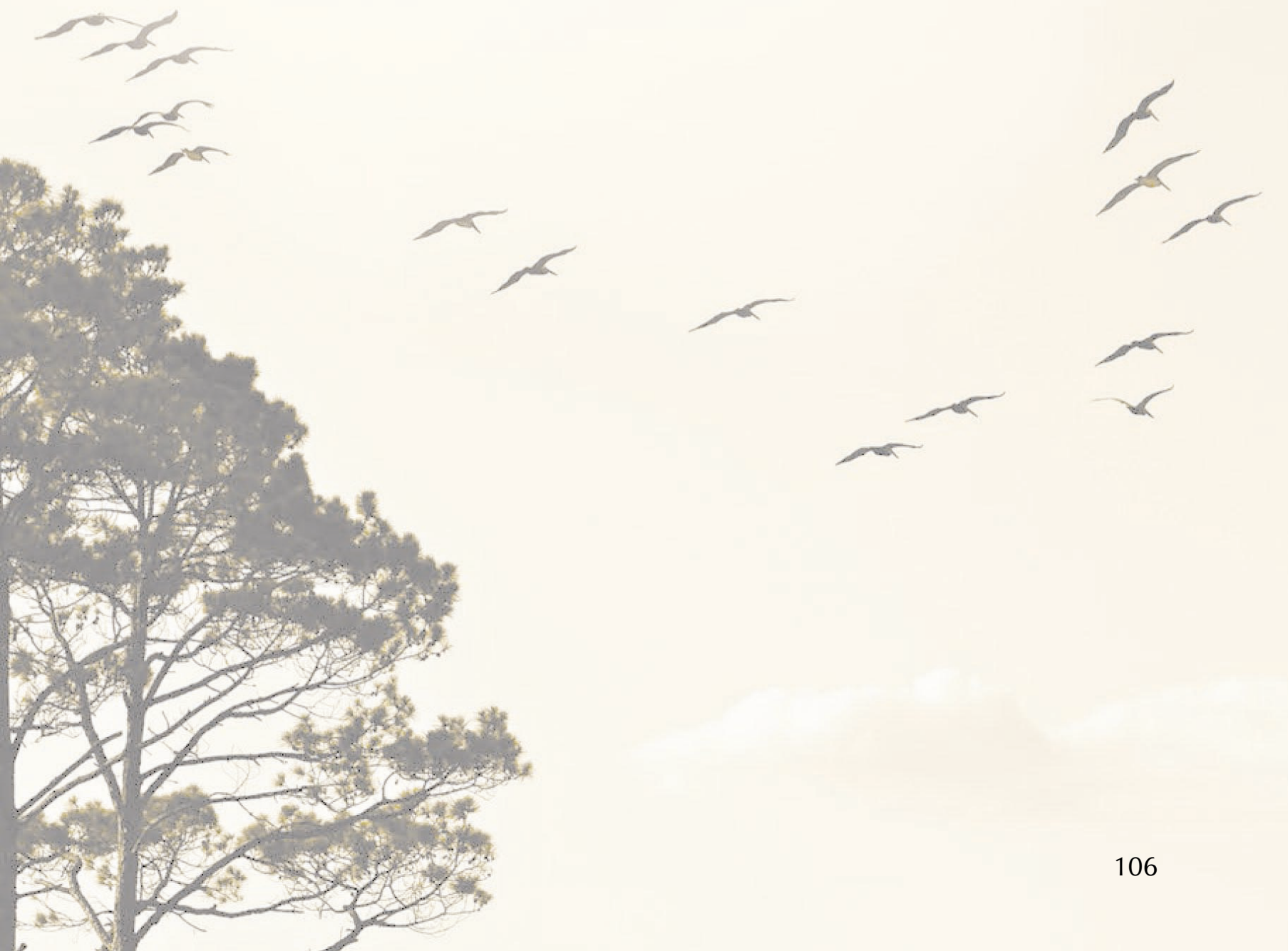


Resumo: Este relato aborda a mediação como um recurso estratégico no ensino de PLAc (Português como Língua de Acolhimento). A palavra mediação aqui está sendo usada como uma disposição de tratar a língua e a cultura do Outro como patrimônios que favoreçam o enriquecimento cultural de todos que participem no processo de ensino e aprendizagem no grupo de trabalho, ou seja, os(as) alunos(as) haitianos(as) e as professoras brasileiras, ensinam e aprendem simultaneamente. O acolhimento para nós transpassa níveis linguísticos, promovendo uma maior aproximação ao real contexto em que o(a) aluno(a) está inserido(a). Essa prática possibilita, além da fluência em uma nova língua, a ruptura de barreiras xenofóbicas e a construção de pontes humanizadoras para a convivência. Nossa prática didática é eclética, mas segue os princípios do trabalho colaborativo e o ensino Para Fins Específicos, dentro da Abordagem Comunicativa. Trabalhamos as habilidades de compreensão e expressão oral, compreensão e expressão escrita, bem como desenvolvemos a interação comunicativa a partir de temas que vão sendo delimitados de acordo com o direcionamento que os(as) próprios(as) alunos(as) vão sinalizando como sendo importantes para eles(as). Também trabalhamos numa perspectiva de preparação para processos seletivos como o CELPE Bras e vestibulares/ENEM, cuja finalidade é favorecer a continuidade dos estudos dos(as) nossos(as) alunos(as) para que eles(as) tenham melhores oportunidades para alavancar suas condições sociais e profissionais.

Palavras-chave: Ensino e aprendizagem de PLAc. Mediação cultural. Migrantes. IFG-Goiânia.

\section{O acolhimento na perspectiva legal}

ngressamos no projeto de extensão, como voluntárias, no primeiro semestre de 2019, quando o nome era "Acolher, ensinar e aprender: português para imigrantes", e o público-alvo, em grande parte, era de haitianos que estão no Brasil, como portadores de visto humanitário. Há uma diferença importante entre os termos "portador de visto humanitário" e "refugiados", assim, esclarecemos que no Brasil os pedidos de refúgio são regidos pela Lei 9.474/97, que diz:

Art. $1^{\circ}$. Será reconhecido como refugiado todo indivíduo que:

I - devido a fundados temores de perseguição por motivos de raça, religião, nacionalidade, grupo social ou opiniões políticas encontre-se fora de seu país de nacionalidade e não possa ou não queira acolher-se à proteção de tal país;

II - não tendo nacionalidade e estando fora do país onde antes teve sua residência habitual, não possa ou não queira regressar a ele, em função das circunstâncias descritas no inciso anterior;

III - devido a grave e generalizada violação de direitos humanos, é obrigado a deixar seu país de nacionalidade para buscar refúgio em outro país.

O que está previsto na lei que regula a entrada de estrangeiros como refugiados não se aplica aos haitianos, que é a nacionalidade com a qual trabalhamos no projeto de extensão. No caso destes, o Comitê Nacional para os Refugiados (Conare) do Ministério da Justiça e Segurança Pública (MJSP) entende que se trata de acolhimento. 
Nesse sentido, o Conselho Nacional de Imigração, por meio da Resolução Normativa 97/2012, criou uma modalidade de visto permanente, por razões humanitárias, concedido aos haitianos na Embaixada Brasileira em Porto Príncipe. A acolhida humanitária foi concedida devido às graves crises ambientais e econômicas no Haiti. Muitos haitianos haviam perdido suas casas, seus bens, seus parentes, empregos e acesso a alimento e saneamento básico, ou seja, eles foram vítimas de uma catástrofe natural que agravou os problemas de cunho econômico e social que já assolavam o Haiti.

De acordo com Verdélio (2016):

Com 229.699 mortes ao longo dos últimos 20 anos, o Haiti é o país com o maior número de vítimas fatais por catástrofes naturais, segundo relatório da Organização das Nações Unidas (ONU) [...]. O desastre mais mortal dos últimos 20 anos foi o terremoto de janeiro de 2010, que matou mais de 220 mil pessoas.

Diante disso, Luiz Paulo Barreto, do Conare, de acordo com Lima (2019), explicou que "o acolhimento deles tem que ser diferenciado. Nós temos que dar condição de que ele se reconstrua, não reconstruir por aqui a sua vida, mas que ajude a reconstruir o seu país. E que a contribuição brasileira seja no sentido de ele voltar para o país dele".

O projeto de extensão "Movimentos migratórios em V: ensino-aprendizagem de português para falantes de outras línguas - MoVe", proposto pelas professoras Suelene Vaz da Silva e Cleide Araújo Machado, e desenvolvido no Instituto Federal de Educação, Ciência e Tecnologias de Goiás, câmpus Goiânia (IFG), por colaboradores(as) voluntários(as) tem contribuído nesse sentido, pois oportuniza a aprendizagem da língua, literatura e cultura do Brasil, favorecendo a inserção dos aprendizes nos cursos regulares de ensino fundamental e médio, por exemplo, nos cursos técnicos e superiores do próprio IFG, bem como em cursos de graduação de outras instituições públicas de ensino. Espera-se que eles se profissionalizem e se sintam preparados e motivados a voltarem ao Haiti para trabalhar na reconstrução do país, pois eles, costumeiramente, declaram saudade e orgulho da terra natal.

\section{O acolhimento nas perspectivas social e financeira}

Nós, como colaboradoras voluntárias na regência, temos trabalhado com abordagens ecléticas, não nos filiando a uma única metodologia de ensino para favorecer a permanência e êxito dos alunos no curso de extensão. Os alunos são consultados em todos os encontros sobre a relevância do tema, das atividades propostas, sobre o grau de dificuldade, sobre a distância ou proximidade com as experiências culturais do Haiti e sobre outros conhecimentos que eles já tinham em relação ao que vai sendo posto para reflexão. 
Nos semestres anteriores, já trabalhávamos com o máximo de recursos tecnológicos que conhecíamos e dos quais dispúnhamos no espaço físico do IFG, mas em 2020 foram necessários outros conhecimentos para atender às demandas pontuais das aulas no modo remoto, pois, com a pandemia de Covid-19, as aulas presenciais foram suspensas por tempo indeterminado.

As aulas, que eram realizadas semanalmente aos sábados das $18 \mathrm{~h}$ às $20 \mathrm{~h}$, passaram a acontecer duas vezes na semana (segundas e quartas-feiras) das 19h30 às $21 \mathrm{~h}$ pelo Google Meet. Fizemos tentativas de utilização do Classroom e não tivemos sucesso devido às dificuldades dos alunos com os pacotes de internet, ou pela qualidade digital, ou por obsolescência dos aparelhos que alguns deles utilizavam.

O que não conseguíamos realizar com qualidade pelo Google Meet, enviávamos por WhatsApp. Os discentes têm idade e escolaridade variada, de 14 a 54 anos e a maioria é masculina. Alguns alunos não finalizaram o ensino médio e outros já estão no ensino superior, e essa variação do público discente também ajuda a justificar a diferença das estratégias de aprendizagem, bem como maior ou menor facilidade em lidar com tecnologias.

O objetivo da diversidade de metodologias, métodos e técnicas de ensino-aprendizagem aplicada foi tentar não deixar ninguém pelo caminho. Apesar dos esforços da equipe de regência, alguns alunos tiveram dificuldades para acompanhar as aulas. Entre os motivos estão: falta de letramento digital; incompatibilidade de horário de trabalho com as aulas no projeto; estudos regulares em outros cursos de ensino médio ou superior no mesmo turno das aulas no curso de extensão. Por esse fito, alguns desistiram ou assistiam só parcialmente às aulas.

Para amenizar as dificuldades financeiras, o IFG disponibilizou um subsídio de $R$ \$ 10,00 por presença, que era pago no mês seguinte ao da frequência diretamente em uma agência do Banco do Brasil. Os alunos que trabalhavam em horário comercial acabaram não conseguindo receber os valores para ajuda de custo, pois não conseguiam liberação do trabalho para irem a uma agência fazer a retirada. Aos olhos externos esse valor pode ser pouco, mas para os alunos representava uma possibilidade de seguir estudando.

Apesar de as trocas culturais e de experiências terem aumentado, há também os desafios em que muitos alunos precisam se acostumar com as tecnologias atreladas ao ensino-aprendizagem. No início, a adaptação aos recursos tecnológicos foi um tanto complicada, como utilizar as plataformas ou entregar tarefas dentro de um prazo determinado.

Como regentes, fomos adaptando as estratégias e procedimentos de ensino para facilitar a aprendizagem da maneira mais adequada aos alunos, para que tudo fosse mais leve e que não desmotivasse ninguém. Além disso, é possível notar a empatia que os alunos possuem reciprocamente quando compartilham os aparelhos celulares 
para assistir às aulas, a motivação que eles promovem entre si, e, por fim, a disponibilidade para auxiliarem uns aos outros nas atividades de casa. Tal empatia pode ser fruto da convivência em comunidade no grupo religioso que os acolhe, na relação de pertencimento a um grupo social e em função do vínculo afetivo, que foi se consolidando entre alunos(as) e professoras no projeto de extensão MoVe.

No começo, com os desafios impostos pela tecnologia, os alunos e alunas não interagiam muito, por ser tudo novo para todos e todas, mas com o tempo e com incentivo metódico isso mudou e eles voltaram a interagir mais. Para isso, o estímulo precisa ser constante e em decorrência dessa necessidade é preciso mandar mensagens no WhatsApp, conversar com eles, trazê-los de volta para a aula, ajudá-los com as tecnologias, com a conexão de internet, etc.

Enfim, é indispensável sempre dar o apoio necessário para que o aluno não desista do curso, posto que este pode servir de apoio para alcançarem melhores oportunidades de vida no Brasil. Sobre os conteúdos, é importante destacar que buscamos abranger temas linguísticos (gramaticais e funcionais), culturais (costumes, comidas, festas típicas, expressões idiomáticas), históricos (datas comemorativas, acontecimentos relevantes, questões políticas, questões de racismo), legais (direito do migrante, do consumidor, da mulher), etc. Isso parece ter promovido um envolvimento dos alunos, mesmo no modo remoto, pois as aulas não perderam sua qualidade, apenas tivemos que nos adaptar ao novo contexto que estávamos vivenciando naquele momento.

\section{O acolhimento como atitude de reciprocidade}

Quando entramos no projeto em 2019, de início houve um entusiasmo enorme, visto que se tratava de uma oportunidade nova para professoras em formação, cursando ainda o segundo período do curso de Licenciatura em Letras: Língua Portuguesa. Ao mesmo tempo surgiram inseguranças, já que nunca havíamos estado em sala de aula desempenhando a função de professoras. Inspiramo-nos naqueles mestres e mestras que admiramos como alunas e tentamos repassar aos nossos alunos aquela mesma sensação que sentíamos quando discentes: de estarmos acolhidas, de podermos nos expressar em sala de aula, de não nos acanharmos quando houvesse dúvidas. Em relação a esse processo, concordamos com Freire (1996, p. 12), quando diz que:

Ensinar inexiste sem aprender e vice-versa e foi aprendendo socialmente que, historicamente, mulheres e homens descobriram que era possível ensinar. Foi assim, socialmente aprendendo, que ao longo dos tempos mulheres e homens perceberam que era possível - depois, preciso - trabalhar maneiras, caminhos, métodos de ensinar. Aprender precedeu ensinar ou, em outras palavras, ensinar se diluía na experiência realmente fundante de aprender. 
Assim, o primeiro contato com a sala de aula no projeto foi mais leve e o acoIhimento citado foi mútuo, a relação de ensino-aprendizagem tornou-se muito mais proveitosa, pois os alunos, mesmo com suas longas jornadas de trabalho, estavam ali dispostos para aprender o conteúdo sem perder o entusiasmo, uma vez que eles precisavam aprender a língua do país em que se encontravam.

Nesse sentido, devemos mencionar Almeida Filho (2002) quando explica que o(a) licenciando(a) já sabe o que é ser professor(a) pela experiência de ter sido aluno(a). O autor usa o termo "competência implícita" para designar o acúmulo de experiências vividas na profissão em momento anterior à graduação universitária e acrescenta que essa é a competência mais básica, constituída de intuições, crenças e experiências.

No planejamento e na execução das aulas, tivemos que desconstruir e reconstruir muitas crenças, uma delas foi a compreensão de que o professor não tem que saber tudo, porque ele vai aprendendo à medida que vai sendo questionado. Outro aprendizado foi entender que o aluno é o centro do processo e não o professor, então é preciso ir ampliando os turnos de fala dos alunos. Mas esse também tem sido um aprendizado difícil para o aluno haitiano que se acostumou à obediência e ao silêncio em sala de aula.

Nosso esforço, atualmente, é conseguir deter no máximo 30\% do turno de fala num encontro, o restante do tempo deve ser dos alunos, para que possam exercitar a língua, além de demonstrar suas dúvidas, suas experiências, seu aprendizado, seja por meio da leitura, da escrita, da compreensão oral ou da interação oral comunicativa. Nosso papel é mediar culturalmente a aprendizagem, apresentar estruturas funcionais e esclarecer questões gramaticais para que eles possam se desenvolver na comunicação oral e escrita. O protagonismo deve ficar com eles e não conosco, e isso não significa negar a exposição de temas ou exercer o papel tradicional de professoras, mas instigar a curiosidade constante para que eles possam ser autônomos e reflexivos para além da sala de aula.

O projeto de extensão de português para estrangeiros surgiu como uma grande oportunidade para exercer a profissão de professoras dentro da sala de aula. Porém, o português na perspectiva de língua de acolhimento (PLAc) possui um "toque especial" que sensibiliza todos os envolvidos naquela situação. É um abrir os olhos para um mundo novo, o mundo do outro e ao mesmo tempo seu. É poder compartilhar conteúdos diversos com os alunos, mas também aprender sobre a visão dos migrantes que aqui se encontram.

Há uma troca cultural gigantesca e cada aula parece um intercâmbio entre países, costumes e culturas. Além disso, transformações internas ocorrem em todos os envolvidos, conseguimos nos analisar e perceber como atuar em sala de aula, fazendo adequações em nossas metodologias e práticas, ademais da prática humanizadora 
de se emocionar com o progresso dos alunos, de nos sentirmos responsáveis por fazermos parte da formação de um outro indivíduo.

Em relação às transformações que ocorrem nos alunos é preciso destacar o choque cultural e seu constante progresso na aprendizagem de um novo idioma, porém o processo não abrange apenas o descobrimento de uma nova língua, mas todo o contexto por trás desta: novas ideologias, novos indivíduos, culturas, crenças, entre tantas outras coisas. Segundo Vilaseca (2000), quando uma pessoa entra em contato pela primeira vez com uma nova cultura, produz-se um choque cultural. O que significa que essa nova cultura aos olhos de quem está aprendendo outra língua pode representar algo negativo ou positivo.

Essa vertente do trabalho que realizamos foi interessante, pois uma parte dos haitianos do grupo sob nossa regência frequentava a Igreja Metodista e outros não, embora não saibamos precisar o número dos frequentadores da vertente religiosa, era possível observar que a visão cultural deles sobre os temas levados à sala, às vezes, divergia.

Entre os temas que geraram reflexões mais calorosas estava a liberdade de escoIha e de expressão, garantida pela legislação brasileira, por exemplo nas questões da diversidade religiosa e de gênero, os papéis sociais da mulher, seus direitos e os tipos de violência contra ela. Embora tenha havido desconforto para alguns alunos, quando os temas foram estudados, houve a defesa entre eles sobre a compreensão de que Haiti e Brasil são países diferentes com pontos em comum e pontos divergentes e que o respeito ao outro era muito importante para uma boa convivência.

Na visão de Núñez Vázquez (2009), as relações entre culturas ou interculturalidade podem ser compreendidas como sendo uma relação dialógica entre culturas, na qual se busca estabelecer interação, mediação, negociação e não uma absorção total de uma cultura pela outra, chamada de aculturação. Nessa direção, nosso trabaIho ressalta a importância de identificar como são as práticas sociais no Brasil e como são no Haiti de modo a identificar em que se aproximam ou se distanciam. Além disso, frequentemente destacamos que é esperado que haja diferenças entre os povos e isso não representa um problema quando adotamos um comportamento intercultural em lugar de etnocêntrico.

Em nosso primeiro semestre no projeto, ainda na modalidade presencial, trabalhamos com uma turma de adolescentes. Muitos deles já estavam no Brasil há um tempo e estudavam em escolas brasileiras, regularmente matriculados. Assim, observamos que seu desenvolvimento com o português brasileiro era mais rápido, tinham uma maior facilidade para entender os temas abordados em aula, no entanto, as distrações eram mais frequentes, pois eles, muitas vezes, começavam a conversar entre si, contando suas experiências nas escolas brasileiras.

Como alguns temas eram abordados de forma diferente no projeto de extensão e na escola regular, às vezes isso confundia a mente deles, provocando uma reflexão 
entre eles e entre nós sobre "qual o jeito certo de ensinar?". Tal experiência foi muito rica, pois conseguimos apresentar para a turma as diversas formas de aprender e ensinar. Muitas vezes utilizamos recursos tecnológicos e metodologias diversas para envolvê-los cada vez mais na temática da aula.

Já no segundo semestre de 2019, a turma dos adolescentes, devido ao baixo número de integrantes, foi incorporada à turma dos alunos que queriam prestar vestibular. Naquele momento as idades eram diversas e, consequentemente, o nível de envolvimento com a língua portuguesa também. Enquanto os mais velhos utilizavam a língua portuguesa apenas durante o trabalho que tinham aqui no Brasil, as crianças utilizavam em grande parte do tempo: dentro da sala de aula, com os amigos e até entre seus familiares, mesmo que, muitas vezes, fosse solicitado que eles falassem sua língua de herança - o crioulo haitiano.

Abordamos em aula, então, um aspecto muito importante, o de não anular uma língua pela outra, pois o crioulo haitiano é uma língua muito rica e é um traço identitário dos nossos alunos. Assim, passamos a sempre perguntar, no decorrer das aulas de português, algumas palavras e/ou frases na língua deles, nós, professoras, também demonstramos interesse para conhecer a cultura e lugar de origem dos nossos alunos, gerando uma troca cultural muito rica e mútua.

Nas palavras de Freire (1992):

Ensinar e aprender são assim momentos de um processo maior - o de conhecer, que implica re-conhecer. No fundo, o que eu quero dizer é que o educando se torna realmente educando quando e na medida em que conhece, ou vai conhecendo os conteúdos, os objetos cognoscíveis, e não na medida em que o educador vai depositando nele a descrição dos objetos, ou dos conteúdos.

Nesse sentido, fomos aprendendo saudações, equivalências de expressões idiomáticas, maneiras e preferências de preparação de alimentos, ritos de passagem como o casamento, enfim, vocabulário e cultura haitiana. Nosso interesse pela língua e cultura dos haitianos favoreceu uma maior aproximação entre a relação professor-aluno, além de tê-los potencializado a se dedicarem mais nos estudos, a fim de tornar a aprendizagem mais leve e proveitosa. Desse modo, nossa prática não foi conteudista, nem unidirecional, o conhecimento na/da língua e cultura brasileira foi sendo construído junto com a turma.

Eles se alegravam com nosso Bonswa! para começar o encontro ou bon nuit tout moun! ao nos despedirmos. E nós nos sentíamos recompensadas com o empenho e dedicação deles na aprendizagem do português, assim como no esforço para que nós pronunciássemos, adequadamente, as palavras na língua deles. Assim, todos nós, que estivemos na turma, exercitamos todo o tempo o lugar de docentes e de discentes. 


\section{A mediação como recurso estratégico no ensino de PLAC}

O ensino de PLAc pressupõe uma formação específica para o desenvolvimento da percepção sobre o que é mais relevante hierarquicamente para a aprendizagem da língua. Habitualmente no processo de ensino e aprendizagem, o estudante se encontra em situação de fragilização emocional, financeira, social e o professor precisa desenvolver sua capacidade de percepção para as diferentes urgências que podem existir em sua sala de aula.

Não é papel do professor atuar como representante legal desse aluno, nem como psicólogo ou orientador religioso, mas lhe cabe ter a sensibilidade para fazer planejamentos de aulas com temas que possam favorecer o desenvolvimento do discente. Dito isso, é mister recordar que nosso planejamento primou por iniciar as aulas com atividades lúdicas, mas conectadas com o que havia sido trabalhado na aula anterior e com a aula daquele dia.

Consideramos importante que no início de cada aula haja uma atividade de aquecimento, na qual o estudante possa manifestar em língua portuguesa o que já sabe e que o professor possa mapear o que o aluno ainda não produz adequadamente na língua-alvo. Também, observamos nas atividades de aquecimento que, dependendo do que era proposto nos primeiros minutos de aula, o grupo ficava mais ou menos participativo.

Fizemos um esforço coletivo para que o ritmo animado durante um mesmo encontro se mantivesse do início ao final, assim, mesmo nos momentos mais expositivos da aula, os alunos não se dispersavam. Ademais, com o diagnóstico das necessidades mais urgentes do grupo, buscamos fazer uma seleção e um planejamento de atividades que privilegiassem conhecimentos que ultrapassassem questões de língua(gem) e gramática, e que envolvessem a cultura e a literatura brasileira.

Trabalhamos com a gramática contextualizada e focamos nos elementos funcionais, ou seja, ao apresentar uma música, uma poesia, um conto, uma crônica, um anúncio, uma reportagem, entre os objetivos estavam ampliar vocabulário geral, ampliar o repertório sociocultural, estabelecer relações de causa e efeito oriundos de determinados scripts esperados culturalmente, falar dos eventos sociais/culturais mais praticados e seus significados. À medida que íamos apresentando a língua, a literatura e a cultura brasileiras, íamos estimulando os alunos a manifestarem como eram esses mesmos fenômenos no país de origem.

Nem sempre havia equivalência, então identificar as diferenças era surpreendente, sempre. Desse modo, buscamos ter em mente o que dizia Freire (1996, p. 12), no sentido de que o estudante "(...) desde o princípio mesmo de sua experiência formadora, assumindo-se como sujeito também da produção do saber, se convença definitivamente de que ensinar não é transferir conhecimento, mas criar as possibilidades para a sua produção ou a sua construção". 
Simulamos, por meio de atividades lúdicas ou de teatralização de diálogos para situações específicas, muitas circunstâncias que poderiam ocorrer na vida dos alunos, por exemplo, entrevista de trabalho, convivência em sala de aula, realização de compras pedindo descontos. Nem tudo que preparamos saiu como esperávamos, houve momentos de pensarmos que a aula seria muito motivadora e não foi porque eram temas tabus, como ocorreu na abordagem sobre o direito das mulheres ou questões de gênero.

A ideia era trazer para a sala de aula questões com as quais os alunos iriam se deparar mais cedo ou mais tarde no Brasil e que isso pudesse contribuir com a redução de possíveis desconfortos por não compreenderem o contexto. Uma das questões mais intrigantes e impactantes que observamos foi o reconhecimento deles de que no Brasil havia racismo, e que essa temática não era discutida no Haiti. Sentir que a pele retinta poderia representar obstáculo para alcançar sucesso profissional ou inserção social foi uma experiência muito triste. Desse modo, fomos tentando trazer para a sala os discursos empoderadores, por meio da reflexão, da compreensão dos direitos das pessoas no Brasil, das lutas que precisam ser enfrentadas por todos.

Acreditamos no que diz Freire (2000, p. 13) ao defender que:

[u]ma das primordiais tarefas da pedagogia crítica radical libertadora... é trabalhar contra a força da ideologia fatalista dominante, que estimula a imobilidade dos oprimidos e sua acomodação à realidade injusta, necessária ao movimento dos dominadores. É defender uma prática docente em que o ensino rigoroso dos conteúdos jamais se faça de forma fria, mecânica e mentirosamente neutra.

Nosso papel preponderante nas aulas foi o de mediadoras, estávamos sempre atentas ao que os alunos já sabiam e ao que iam sinalizando que precisavam aprender. Sobre o que precisavam aprender, nos baseamos nas necessidades específicas que eles iam nos apresentando e na experiência que temos sobre o que é ser brasileiro, adepto a determinadas religiões, pertencente a determinados estratos sociais, pelos traços físicos característicos, pelo gênero, etc.

Sobre a mediação é preciso retomar Vygotsky, que, de acordo com Oliveira (1993, p. 28), se trata de um "processo de intervenção de um elemento intermediário numa relação; a relação deixa, então, de ser direta e passa a ser mediada por esse elemento". Nesse sentido, a reflexão sobre assuntos variados possibilitou que eles pudessem conhecer vertentes do comportamento cultural brasileiro que ainda não tinham identificado. $\mathrm{E}$ ao conhecer novas facetas dos costumes, mesmo não tendo enfrentado concretamente alguns dos aspectos que fomos problematizando, puderam se instrumentalizar de língua(gens) que os protegessem e os empoderassem, fazendo valer o imperativo de que respeitar e ser respeitado é um direito.

Ainda, apoiando-nos em Oliveira (1993, p. 37), é importante destacar que a: 


\begin{abstract}
Capacidade de lidar com representações que substituem o próprio real é que possibilita ao homem libertar-se do espaço e do tempo presentes, fazer relações mentais na ausência das próprias coisas, imaginar, fazer planos e ter intenções. (,,, Essas possibilidades de operação mental não constituem uma relação direta com o mundo real fisicamente presente; a relação é mediada pelos signos internalizados que representam os elementos do mundo, libertando o homem da necessidade de interação concreta com os objetos de seu pensamento.
\end{abstract}

Ao pesquisar na internet o significado de "mediar", o Dicionário Online de Português (Dicio) abrange a seguinte definição: "tratar ou discutir como mediador, mediatizar. Estar no meio; distar igualmente". Sendo assim, procuramos abordar esse sentido como fundamental nas aulas de ensino do PLAc, pois o aluno não deve ser visto como uma espécie de "recipiente" em que o professor deposita o conhecimento. $\mathrm{O}$ ato de educar deve prever interação, argumentação, contestação e posicionamento crítico. O aluno constrói o conhecimento juntamente com o professor e com os colegas, assim deve haver a troca de conhecimento.

Durante as aulas procuramos trazer temas amplos, normalmente culturais, sobre os quais os alunos possuem um maior conhecimento para que pudessem assumir o papel de nos ensinar. Fizemos perguntas constantes, tais como: "como isso funciona no Haiti?", "quais são as lendas mais comuns no país de vocês?", "quais são os pratos típicos da culinária haitiana?", "como é o casamento no Haiti?".

Assim, os alunos foram se sentindo mais confortáveis e confiantes para falar de assuntos sobre os quais eles já possuem repertório intercultural. Nessa perspectiva, os temas das aulas são escolhidos com a intenção de que a interação entre os envolvidos no projeto seja significativa. Procuramos assim, que a sala de aula seja, sempre, um ambiente aberto para o diálogo.

Alguns alunos preferem temas culturais, outros nos cobram as regras gramaticais da língua portuguesa e há aqueles que preferem temas relacionados à literatura brasileira. Oferecer brincadeiras/atividades lúdicas como aquecimento é sempre uma boa opção, pois os alunos se envolvem mais com o conteúdo da aula.

Além disso, apresentar músicas, charges e vídeos também cativa a atenção da turma, principalmente se as músicas forem mais animadas, como algumas clássicas da MPB. Já em relação às normas gramaticais, por mais que os alunos afirmem que só conseguem se desenvolver na língua através delas, o conteúdo muito voltado para a gramática fica, às vezes, um tanto enfadonho, por isso nossa decisão foi trabalhar gramática contextualizada nos textos de tipos e gêneros diversificados.

Essa necessidade de estudar gramática numa abordagem mais estruturalista é uma crença carregada pelos alunos e influenciada pela cultura haitiana, pois nas escolas de lá eles aprendiam o francês privilegiando-se as regras gramaticais, da mesma forma que, costumeiramente, aprendemos o português no Brasil durante os anos regulares da escolarização. Porém, o que esquecemos é que estamos em contato com 
a língua o tempo todo, através de nossas relações pessoais, profissionais, sociais, religiosas, culturais, enfim, na vida cotidiana. Desse modo, acreditamos que é preciso apreender a língua para expressar significados identitários, para se representar ideologicamente, para atuar nas transformações do entorno, etc.

\section{Mediação cultural}

Como visto no subitem anterior, a mediação para Vygotsky é o que possibilita a aprendizagem e pode ser o meio no qual o indivíduo se depara com o elemento responsável pela mediação ou com uma pessoa que tenha mais conhecimento e que compartilha de maneira significativa com aquele que sabe menos.

Perrotti (2016 apud RASTELI; CALDAS, 2017, p. 155) acredita que:

Definir a mediação cultural é uma tarefa que se encontra ainda em processo e não se pode afirmar que já se trata, apesar de avanços significativos, de uma noção dotada de estabilidade, referindo-se a realidades e/ou fenômenos tomados em um mesmo e preciso sentido. Entende-se, desse modo, que a mediação cultural pode se tratar de um processo concebido como produção simbólica e material que têm lugar na dinâmica interativa circunscrita em uma relação de sujeito-sujeito-objeto na construção do conhecimento.

E continua (2017, p. 157):

A mediação cultural é uma forma mais recente de atividades culturais elaboradas - tanto em termos de prática profissional e da relação com o público, como o discurso e ações do Estado - por causa de sua importância política e cívica. Com efeito, a mediação cultural, tal como concebida pelos decisores políticos e as partes interessadas culturalmente, pretende trabalhar em conjunto no sentido de (a vida com o pensamento) e ao nível de vida em coletividade. Este método de intervenção cultural destina-se a restabelecer laços sociais e de inventar novas sociabilidades, buscando fazer a ponte entre o indivíduo e a comunidade, cultura e política, arte e sociedade. Isso implica uma transformação das relações sociais, ao mesmo tempo uma evolução significativa das transmissões culturais.

Nessa perspectiva, destacamos o quão gratificante é atuar no papel de professoras mediadoras, inovando nos recursos metodológicos e, consequentemente, no ensino. Assim, o processo de ensino-aprendizagem torna-se mais atrativo e proveitoso, possibilitando uma maior participação da figura fundamental no meio disso tudo: o aluno.

Um exemplo disso foi quando optamos por abordar sobre o racismo, com total cautela, por não se tratar do nosso local de fala e, ao mesmo tempo, proporcionando ao aluno um maior empoderamento sobre si mesmo e seus direitos como cidadão. Esse mesmo empoderamento torna-se visível nas mulheres haitianas que ca- 
da vez mais expressam suas opiniões e posicionamentos durante as aulas do projeto MoVe, visto que, por outro lado, em uma sala no seu país de origem, estas alunas iriam acanhar-se.

Para as reflexões, nos apoiamos em textos de Carolina Maria de Jesus, como o "Quarto de despejo", que inclusive foi explorado em um dos vestibulares do IFG; pinturas ou fotografias expostas em lugares como o Museu de Arte de São Paulo (MASP); músicas; notícias; filmes como "Escritores da Liberdade" e "Histórias cruzadas"; charges, etc.

Já em relação às experiências vivenciadas pelas professoras, é relevante destacar que a atuação como mediadoras pode ser uma experiência transformadora, tendo em vista que em boa parte de nossa vida escolar não recebemos esse destaque, essa oportunidade de poder levantar opiniões, pensamentos e, às vezes, até nossas dúvidas.

Depois de atuarmos no projeto de extensão MoVe, o maior estranhamento que vivenciamos é causado ao nos depararmos com uma sala de aula tradicionalmente brasileira e com os desafios propostos pelos métodos e conteúdos já estabelecidos pela coordenação ou instâncias superiores.

Apesar das dificuldades que enfrentamos nas escolas brasileiras para ensinar português como língua materna é importante insistir nos esforços de inovar, de dar o "pontapé" inicial para que a mudança desejada ocorra e que esta seja transformadora, em outras palavras, que a escola não seja apenas lugar de memorização de regras, mas de compreensão de que somos seres sociais que por meio da língua(gem) podemos agir e construir coletivamente um mundo menos ruim.

A mediação, portanto, possui esse caráter progressista que tem muito a contribuir com todos os envolvidos no processo. $\mathrm{O}$ ato de mediar pode ser visto como também o de humanizar, tanto a si mesmo quanto ao outro. É a capacidade de possibilitar que o mundo seja visto nas diversas perspectivas que o rodeiam.

Segundo os autores Kupiec, Neitzel e Carvalho (2014, p. 165):

[a] mediação cultural circula em torno da necessidade do acesso à arte como componente essencial na humanização do homem, e como possibilidade de ampliação de nossa capacidade perceptiva, expressiva e reflexiva (...). Por isso, a mediação cultural efetuada pelo professor - compreendida como resultante do entrecruzamento de conhecimentos artísticos, estéticos e políticos -, pode potencializar a cultura como fator de desenvolvimento humano.

Por fim, perceber esse desenvolvimento tanto dos alunos quanto das professoras se torna combustível para aprimorar metodologias e proporcionar aos alunos um processo de ensino e aprendizado adequado aos diferentes contextos, que possibilitará uma mudança considerável em sua/nossa realidade. Ademais, trabalhar com o ensino de PLAc resume-se basicamente a isso: promover pontes humanizadoras entre 
o universo da sala de aula e da sociedade como um todo, capacitando todos os envolvidos nesse processo.

\section{Referências}

ALMEIDA FILHO, J. C. P. de. Dimensões comunicativas no ensino de línguas. 3. ed. Campinas, SP: Pontes, 2002.

BRASIL. Congresso Nacional. Lei no 9.474, de 22 de julho de 1997. Disponível em: http://www.planalto.gov.br/ccivil_03/leis/l9474.htm. Acesso em: 8 nov. 2020.

FREIRE, P. Pedagogia da Autonomia. 25. ed. São Paulo: Paz e Terra, 1996.

FREIRE, P. Pedagogia da Esperança: Um reencontro com a Pedagogia do Oprimido. Rio de Janeiro: Paz e Terra, 1992. Disponível em: https:/www.finom.edu.br/assets/ uploads/cursos/categoriasdownloads/files/20190628210617.pdf. Acesso em: 11 nov. 2020.

FREIRE, P. Pedagogia da indignação: cartas pedagógicas e outros escritos. São Paulo: UNESP, 2000.

KUPIEC, A.; NEITZEL, A. de A.; CARVALHO, C. A mediação cultural e o processo de humanização do homem. Revista Antares: Letras e Humanidades, Caxias do Sul, RS, v. 6, n. 11, p. 163-177, jan./jun. 2014. Disponível em: http://www.ucs.br/etc/revistas/ index.php/antares/article/view/2565. Acesso em: 6 dez. 2020.

LIMA, V. Câmera dos Deputados. Radio Câmera. Refugiados - A situação dos haitianos. ed. 33. Set. 2019. Disponível em: https://www.camara.leg.br/radio/programas/354223-refugiados-a-situacao-dos-haitianos-0648/?pagina $=33 \#: \sim$ :text $=$ Eles $\% 20$ eram $\% 20$ v\%C3\%ADtimas \%20de\%20uma,existe \% 20ref\%C3\%BAgio\%20por\% 20causas \% 20 naturais.\%22. Acesso em: 11 dez. 2020.

MARTIN \& Oliveira Sociedade de Advogados. Jusbrasil. Refúgio x Visto Humanitário - Diferenças. Disponível em: https://martinoliveira.jusbrasil.com.br/artigos/ 676648935/refugio-x-visto-humanitario-diferencas, 2018. Acesso em 4 nov. 2020.

NÚÑEZ VÁZQUEZ, I. La adaptación del currículo escolar a la diversidad cultural. Revista Iberoamerciana de Educación, Madrid, España, n. 49/2, p. 1-9, 10 abr. 2009. Disponível em: https://doi.org/10.35362/rie4922102. Acesso em: 3 nov. 2020. 
OLIVEIRA, M. K. Vygotsky: aprendizado e desenvolvimento - um processo sócio-histórico. São Paulo: Scipione, 1993.

RASTELI, A.; CALDAS, R. F. Percepções sobre a mediação cultural em bibliotecas na literatura nacional e estrangeira. Revista TransInformação, Campinas, v. 29, n. 2, p. 151-161, maio/ago. 2017. Disponível em: https://doi.org/10.1590/231808892017000200003. Acesso em: 14 nov. 2020.

VERDÉLIO, A. Agência Brasil. Haiti é o país com maior número de mortes por catástrofes naturais, diz ONU. Publicado em 13 out. 2016. Disponível em: https:// agenciabrasil.ebc.com.br/geral/noticia/2016-10/haiti-e-o-pais-com-maior-numero-de-mortes-por-catastrofes-naturais-diz-onu. Acesso em: 14 out. 2020.

VILASECA, A. O. Hacia la competencia intercultural en el aprendizaje de una lengua extranjera: estudio de choque cultural y los malentendidos. Madrid: Editorial Edinumen, 2000. 
Resumo: Este relato apresenta um recorte das experiências de três regentes, Angélica, Fabiana e Nayara, no Projeto de Extensão "Movimentos migratórios em V: ensino-aprendizagem de português para falantes de outras línguas (MoVe)". Ficamos responsáveis por ministrar aulas de Português como Língua de Acolhimento (PLAc) para dezessete venezuelanos com foco em processos de vestibular e/ou certificado de proficiência em Língua Portuguesa para Estrangeiros (Celpe-Bras). As aulas preparadas com base na indissociabilidade dos aspectos culturais, literários e linguísticos da língua portuguesa do Brasil não se afiliam a uma metodologia de ensino única, são flexíveis e ecléticas, pois, dependendo das necessidades que vão sendo apresentadas durante elas, a escolha de material didático, de temas, de estratégias e procedimentos didáticos vão sendo adequados ao contexto. Os objetivos principais são "acolher", "estabelecer vínculo" e "auxiliar os alunos na aprendizagem e/ou desenvolvimento da comunicação". Vale destacar que as aulas são ministradas de forma a deixar em evidência a necessidade de troca(s) de experiência(s), que se configura $(\mathrm{m})$ no aprendizado mútuo. No ensino remoto, várias foram as dificuldades identificadas e que têm favorecido a desistência de alguns alunos do curso, bem como a oscilação na frequência. O desafio em manter os alunos atentos e presentes nas aulas presenciais não é diferente em aulas remotas. É sobre essas experiências que têm enriquecido nossa formação docente que falaremos, porque acreditamos que, apesar das dificuldades, o que sobressai é a certeza de que as trocas interculturais são as que mais movimentam as aulas e se tornam uma conexão entre regentes e alunos.

Palavras-chave: Experiência docente. Ensino-aprendizagem de PLAc. Ensino remoto. Venezuelanos. Interculturalidade.

\section{O contexto de ensino de português para migrantes em tempos de Covid-19}

ano de 2020 não economizou nas surpresas, tanto em âmbito nacional
quanto no mundial. Santos (2020, p. 5) diz, ainda que em tom de ironia, que:

[se torna] possível ficar em casa e voltar a ter tempo para ler um livro e passar mais tempo com os filhos, consumir menos, dispensar o vício de passar o tempo nos centros comerciais, olhando para o que está à venda e esquecendo tudo o que se quer, mas que só se pode obter por outros meios que não a compra.

No entanto, de encontro ao que diz Santos (2020), as pessoas, em praticamente todas as profissões, em vez de recuperar o direito ao tempo livre, passaram a se dedicar muito mais horas do dia tanto ao aprendizado de recursos para desenvolverem seu trabalho quanto propriamente no desenvolvimento deste.

Uma das surpresas, advindas da pandemia da Covid-19, que afetou o Brasil de maneira mais contundente em 2020, acarretou a migração de muitas atividades de ensino, de diferentes instituições educacionais, para o Ensino Remoto Emergencial (ERE) como medida provisória para evitar o aglomeramento de pessoas, por conseguinte, reduzir a propagação do vírus. Essa migração configurou-se na adoção de aulas síncronas e assíncronas no ambiente virtual, o que provocou uma corrida contra 
o tempo na aprendizagem de ferramentas tecnológicas, por parte dos professores e dos estudantes.

Almeida e Alves (2020, p. 4) enfatizam que: "O conteúdo programático e a informação, que antes estavam concentrados em espaços e dispositivos físicos, como nas bibliotecas, nas escolas e nos livros didáticos, hoje estão disponíveis no ciberespaço". E acrescentam que:

As instituições de ensino, os professores e os próprios estudantes vêm encontrando dificuldades de adaptação ao modelo de ensino remoto devido a questões de acesso às tecnologias digitais de um modo geral, a falta de um ambiente familiar que propicie o aprendizado remoto e a não formação dos alunos e profissionais com os ambientes virtuais devido a questões associadas ao letramento digital. Devido a essas dificuldades, a implantação da educação remota vem evidenciando ainda mais as disparidades socioeconômicas e culturais existentes no nosso país.

Concordamos com as autoras, pois o projeto de Extensão "Movimentos migratórios em V: ensino-aprendizagem de português para falantes de outras línguas - MoVe", que desenvolvemos no Instituto Federal de Educação, Ciências e Tecnologias de Goiás (IFG), câmpus Goiânia, em 2020 deixou de ter aulas de português para migrantes na modalidade presencial e passou a ser totalmente executado em plataformas virtuais. Para a turma abordada neste estudo, migrantes venezuelanos, houve a tentativa de utilizarmos o Google Classroom, porém, apesar dos esforços de todos as professoras regentes no envio de tutoriais e aulas síncronas no intento de auxiliar na aprendizagem dos recursos tecnológicos, muitos alunos não conseguiram se adaptar e desistiram ao longo das aulas.

Almeida e Alves (2020, p. 7) reforçam a ideia de que:

É preciso reconhecer o letramento digital de maneira ampliada, como um conceito associado a práticas sociais que influenciam, também, culturas e pessoas que não dominam a escrita. Ou seja, o letramento digital ultrapassa o âmbito do domínio de técnicas, habilidades e capacidades de uso da leitura e escrita na tela, e passa a ser um processo mais amplo, que atua em diferentes espaços e contextos para além dos muros das escolas.

Assim, entendemos que o trabalho que desenvolvemos no projeto transcende a mera transposição de conhecimentos linguísticos de uma língua de origem a uma língua-alvo, pois se antes já se tratava de forma indissociável língua, cultura e literatura, agora ainda agrega o letramento digital, tão necessário para o mundo do trabalho.

Infelizmente, as limitações sobrepujaram as questões de letramento digital e se justificaram em razão de falta de recursos financeiros para os pacotes de internet, baixa qualidade da internet, obsolescência de aparelhos de celular, incompatibilidade 
de horário de trabalho com o horário das aulas e ambiente familiar com interferências que impossibilitaram vários alunos de seguirem com os estudos.

Por esses motivos, houve um considerável número de desistentes na turma, visto que iniciamos o trabalho de 2020 só em julho. Na expectativa de turma cheia, tivemos dezessete venezuelanos inscritos após a informação de que as aulas seriam somente no modo remoto e, atualmente, contamos com sete matriculados. Havíamos planejado o horário de início às $19 \mathrm{~h} 30$, todavia nossos alunos tinham dificuldade em acessar nesse horário, por trabalhar distante de casa ou por ter que cuidar dos afazeres domésticos, por conseguinte flexibilizamos para iniciar às $19 \mathrm{~h} 50$.

No contexto de pandemia que estamos vivendo, além das diferenças sociais, culturais, econômicas e educacionais, que foram realçadas, há alguns outros fatores que precisam ser considerados como os apontados por Almeida e Alves (2020). Para os autores:

A educação remota vem trazendo um modelo de broadcast, onde os professores transmitem o conteúdo através das plataformas digitais com pouca interação com os alunos, sem se quer ter ideia de como esses sujeitos estão atribuindo sentido aquela determinada temática, configurando o que Jenkins (2009) denominou de unidirecionais. (ALMEIDA; ALVES, 2020, p. 8).

Entendemos e vivenciamos esse tipo de prática como discentes nos nossos estudos de formação inicial ou continuada, mas devemos ressaltar que nossa atuação no projeto, na turma de venezuelanos que acompanhamos, contraria essa tendência atual, dado que, apesar das limitações dos recursos tecnológicos e do distanciamento que está previsto no trabalho por meio de plataformas on-line, as aulas são dialogadas em vez de expositivas; há interação comunicativa aluno-aluno, professor-aluno, professor-professor, professor-orientador e orientador-aluno; há atividades de compreensão e expressão oral, compreensão e expressão escrita nas aulas síncronas; e são trabalhados diferentes gêneros textuais orais e escritos, verbais e não verbais.

Almeida e Alves (2020, p. 13) afirmam que:

[e]nsino remoto nesse contexto não pode ser sinônimo de aula online é necessário que seja adotada metodologias que explorem mais a autonomia e liberdade dos estudantes, aulas que promovam a resolução de problemas, a investigação e a construção cooperativa e colaborativa do conhecimento e a própria valorização do protagonismo desses sujeitos frente ao processo de ensino-aprendizagem.

Ainda que tenhamos enfrentado condições inóspitas para a continuidade do projeto de extensão MoVe, fizemos um movimento de transgressão e resistência e mantivemos as aulas, pois a perspectiva do trabalho é de Português como Língua de Acolhimento - PLAc e essa vertente de atuação docente busca diferentes formas pa- 
ra acolher o estudante, de maneira que se o aluno falta à aula, fazemos contato para identificar a ocorrência, reenviamos material de estudo e atividades de aprendizagem, vídeos de apoio, etc.

Acreditamos que a construção do vínculo afetivo, indispensável no PLAc, no modo remoto acabou sendo mais reforçado que nas aulas presenciais. Apesar do esforço conjunto das professoras na permanência do aluno no curso, vários deles declararam a impossibilidade de continuar no grupo e o desejo de entrar na próxima turma que for aberta. Contudo, nenhuma dificuldade foi capaz de nos desmotivar, pelo contrário, estimulou-nos em relação aos esforços para procurarmos as melhores práticas pedagógicas, visando à melhor aprendizagem da língua.

Fazemos uso da Abordagem Comunicativa Intercultural (ACIN), pois queremos que o estudante desenvolva a competência comunicativa intercultural, que, de acordo com Beneke (2000 apud SÃO BERNARDO, 2016, p. 43), é:

A capacidade de interagir eficazmente com pessoas de culturas que reconhecemos como diferentes da nossa, sabendo que as culturas simultaneamente se assemelham e se diferem em alguns aspectos, como por exemplo crenças, hábitos e valores. Em sentido amplo, competência intercultural é a capacidade de lidar com a própria formação cultural na interação com os outros, interações estas que envolvem o uso de diferentes códigos linguísticos e o contato com pessoas que trazem consigo variados conjuntos de valores e modelos.

Dessa forma, também partimos da perspectiva de uma aprendizagem colaborativa para promover a autonomia e reflexão do aluno, assim como sua responsabilidade pela construção de seu próprio conhecimento, chamando-o para a ação e construção das suas próprias identidades, já em âmbito intercultural, além de poder construir com ele uma interação para desenvolver suas habilidades intelectuais e afetivas (FIGUEIREDO, 2018). Como propulsor do nosso propósito, encontramos os aspectos culturais como aliados no nosso planejamento, é por isso que, desde o início, estamos trabalhando com textos literários, músicas, charges, tirinhas e festividades de cada região.

\section{Valorizando identidades}

Participar do projeto MoVe tem sido um desafio prazeroso, especialmente para nós, professoras voluntárias. É relevante a ampliação da compreensão sobre a importância da formação continuada do docente, visando centrar em cinco grandes linhas, segundo Imbernón (2010), em que o professor precisa refletir sua própria prática através da análise educacional e social de seu país; promover a troca de experiências que possibilitem a atualização em todos os campos de intervenção educacional; unir a 
formação a um projeto de trabalho; utilizar a formação para romper com práticas sociais, como a exclusão e a intolerância; e possibilitar um trabalho colaborativo com a própria instituição.

O exercício docente como regentes voluntárias no PLAc, com foco em processos de vestibular e/ou certificado de proficiência em Língua Portuguesa para Estrangeiros (Celpe-Bras), tem nos feito refletir sobre identidades. Nas palavras de Nóvoa (2000, p. 15), a identidade:

Não é um dado adquirido, não é uma propriedade, não é um produto. A identidade é um lugar de lutas e de conflitos, é um espaço de construção de maneiras de ser e de estar na profissão. Por isso, é mais adequado falar em processo identitário, realçando a mescla dinâmica que caracteriza a maneira como cada um se sente e se diz professor. A construção de identidades passa sempre por um processo complexo graças ao qual cada um se apropria do sentido da sua história pessoal e profissional.

E Moita (2000, p. 115) salienta que:

[n]inguém se forma no vazio. Formar-se supõe troca, experiência, interacções sociais, aprendizagens, um sem fim de relações. Ter acesso ao modo como cada pessoa se forma é ter em conta a singularidade da sua história e sobretudo o modo singular como age, reage e interage com os seus contextos. [...] O processo de formação pode assim considerar-se a dinâmica em que se vai construindo a identidade de uma pessoa. Processo em que cada pessoa, permanecendo ela própria e reconhecendo-se a mesma ao longo da sua história se forma, se transforma em interacção.

Nesse sentido, entendemos que quanto mais praticamos a docência dentro de sala de aula, mais possibilidades de construção de conhecimento acadêmico, social, profissional são suscitadas. E o benefício se estende igualmente entre docentes e alunos, pois no projeto conectamos língua, literatura e cultura. Os venezuelanos nos ensinam sobre seus costumes, músicas, comidas, conflitos, histórias, saudades, e o fazem em língua portuguesa. Assim, à medida que oportunizamos a reflexão ou o desabafo sobre diferentes temas, eles aprendem e nós aprendemos, em outras palavras: intercambiamos conhecimentos que reverberam em nossas identidades.

Ademais, a teoria que fundamenta a prática, estudada na formação inicial, difere-se muito de quando entramos em "ação" com a turma. A experiência in loco nos mostra que devemos estar sempre atentas para possíveis mudanças no que tínhamos planejado ou na maneira que estávamos ministrando o conteúdo, afinal, estamos lidando com pessoas e todos temos uma subjetividade própria. Assim, não temos todas as respostas às perguntas que nos são direcionadas, às vezes, é preciso refletir sobre uma interrogação, não com a finalidade de encontrar soluções, mas com o in- 
tuito de problematizar questões que antes eram invisibilizadas ou naturalizadas entre todos.

O trabalho com PLAc nos prepara para uma nova realidade, posto que ensinar e acolher essas pessoas que se encontram nas mais adversas situações é um desafio constante. Fazemos o nosso melhor para Ihes ensinar a língua portuguesa que, talvez, se viram obrigados a aprender. Entendemos que qualquer um de nós, a qualquer momento, podemos vivenciar o refúgio ou a migração por motivos de força maior e construímos hipóteses sobre a violência que está imbuída nesse processo.

O aprendizado que adquirimos com as trocas culturais é de tanto valor que nos emocionamos. Percebemos que propiciar aos estudantes a oportunidade de falar sobre sua origem, seu país e tudo que isso concerne pode amenizar a dureza do processo de aprender a língua-alvo num movimento de sobrevivência.

Eu, Fabiana Thais Pereira Pedraza, sou boliviana, me identifico com as dificuldades de ter que aprender a língua portuguesa estando já aqui, no Brasil, e tem sido muito gratificante ajudar os venezuelanos nesse processo das dificuldades linguísticas que eu já tive um dia. Isto posto, nós, regentes, procuramos trabalhar na (re)construção da autoestima e do autoconceito dos aprendizes. Defendemos que não existe o falante ideal, ou seja, aquele que não comete equívocos ou que fala como um falante da língua como língua materna, ressaltamos o papel da linguagem como um construtor de identidades, e que ao aprender uma nova língua desenvolvemos a capacidade de remodelar nossa visão de mundo para adicionar a perspectiva do outro, não devemos deixar de mostrar as nossas marcas por meio da identidade linguística, e sim valorizá-la e preservá-la (RAJAGOPALAN, 2003).

\section{A cultura nos planos de aula}

Os elementos culturais têm sido de extrema importância na criação e execução dos planos de ensino, desenvolvidos para as aulas com os alunos venezuelanos. Inicialmente, nosso objetivo, enquanto professoras, era identificar o nível de conhecimento que eles já possuíam da/na língua portuguesa e pontuar algumas dificuldades, com o fito de elaborarmos aulas que atendessem às necessidades específicas do nosso público-alvo. De modo geral, os aprendizes de línguas estrangeiras têm pressa, mas no caso de migrantes e refugiados, a pressa pode significar oportunidades e/ ou sobrevivência.

No processo de aprendizagem de uma nova língua, muitos fatores podem ser facilitadores ou dificultadores e sempre buscamos maneiras de deixar nossos alunos confortáveis durante essa trajetória. A aprendizagem é um processo que pressupõe erros e acertos e é necessário um certo nível de confiança entre os pares, em si mesmo, nas professoras e na metodologia para que a aprendizagem ocorra de forma mais tranquila. 
Nossos alunos são, em sua maioria, adultos e notamos que isso faz com que eles se sintam envergonhados ou inibidos em participar desse processo. $\mathrm{O}$ medo de errar pode impedi-los de tentar e, portanto, de avançar na aprendizagem. Esse medo ou vergonha pode decorrer do filtro afetivo elevado. Para Krashen (1985 apud FIGUEIREDO, 2002, p. 39), o "filtro afetivo é como um bloqueio mental, que impede os indivíduos de utilizarem totalmente o input compreensível que recebem para a aquisição da língua".

Nós, como professoras, nos esforçamos muito para "baixar" esse filtro afetivo e criarmos vínculos de confiança com nossos alunos. Para isso, além das oportunidades de valorização da cultura de origem e da aproximação à cultura brasileira, trabalhamos com atividades lúdicas de aquecimento, priorizamos inicialmente as habilidades de compreensão e expressão oral. Tão logo observamos que se sentem mais confortáveis, vamos introduzindo a compreensão escrita e por último a expressão escrita. A dificuldade vai sendo incrementada de acordo com o consentimento coletivo, de maneira que não seja nem insuficiente, nem excessiva.

As aulas foram ministradas em língua portuguesa desde o primeiro encontro. Em alguns momentos os alunos apresentavam dúvidas ou dificuldades em compreender alguma palavra ou expressão e esgotados os recursos estratégicos sem êxito (exemplificação, sinônimo/antônimo, contextualização, subterfúgios visuais, etc.) nos valíamos da língua de origem, ou seja, do espanhol para esclarecer algumas dessas dúvidas, pois as professoras regentes e a orientadora são falantes de espanhol. Fabiana é boliviana, as demais participantes da equipe são brasileiras, Nayara viajou por diversos países hispânicos, Angélica estudou a língua em nível instrumental e a professora Cleide é graduada em Licenciatura em Letras - Português e Espanhol.

A utilização do espanhol como língua de ancoragem (FIGUEIREDO, 2002) auxiliou na interação inicial e permitiu que estes alunos se sentissem confortáveis em se expressarem conosco, já que quando sentiam dificuldade em falar ou compreender algo se utilizavam do "portunhol" e isso nos dava a oportunidade de apresentar a eles a palavra e expressão pelas quais estavam buscando em português brasileiro.

Os elementos culturais entraram exatamente nessa parte, a de criar um vínculo afetivo. A troca intercultural estimula a interação, o que fez com que nossos alunos se sentissem mais confortáveis para se expressarem verbalmente, além de estimular a participação nas aulas sem o temor de errar. Temas como culinária, festas religiosas e expressões regionais foram de extrema importância para iniciar debates e tornar as aulas cada vez mais interativas.

Nossas aulas seguem uma "estrutura". Buscamos iniciar com algo mais leve, mas que se relacione de alguma maneira com o tema que iremos trabalhar naquela aula. Em uma das aulas, apresentamos uma festa cultural que é muito conhecida na nossa região (Goiás), a Pecuária, e para introduzirmos esse assunto apresentamos 
uma música do gênero sertanejo. Juntamente com a canção também apresentamos a letra para que os alunos pudessem acompanhar conosco. Ao final da música, perguntamos o que eles acharam, se gostaram do ritmo, se compreenderam a letra e naquele momento um dos alunos nos disse que aquela música o fez lembrar de um cantor conhecido na região onde ele morava na Venezuela.

Essa foi a primeira de muitas colaborações que os alunos nos deram em aula. A partir do tema Pecuária, apresentamos alguns pratos típicos da nossa região. Isso os encorajou a falarem dos pratos típicos do seu país de origem e, com a nossa mediação, eles foram os protagonistas dessa interação. Falamos sobre os ingredientes, sobre as semelhanças entres os pratos, sobre o modo de preparo e esses pontos foram cruciais para o diálogo.

Assim como nessa aula, em todas as aulas, a troca foi incrível e essa troca de conhecimento tem sido de extrema importância em nossa formação, enquanto professoras. Vivenciar essa perspectiva de ensino tem ampliado nossa visão sobre ser professoras e temos a certeza de que nos tornará profissionais conscientes de nossa incompletude, ou seja, vamos compreendendo que é ensinando que aprendemos.

A sensação de incompletude que desencadeia a busca constante por novos conhecimentos, novos saberes é, de acordo com Charlot (2003), uma das características que define o homem como "um ser humano", portanto, permeia direta ou indiretamente, o percurso educacional. Para a autora:

- o movimento para aprender é induzido pelo desejo, em razão da incompletude do homem. Esse desejo é desejo de saber, de poder, de ser e, indissociavelmente, desejo de si, desejo do outro (que se procura em si, no outro, no mundo).

- esse desejo não pode jamais ser completamente satisfeito porque, por sua condição, o sujeito humano é incompleto, insatisfeito. Ser completo seria tornar-se um objeto. Nesse sentido, a educação é interminável - jamais será concluída.

- educar é educar-se. Mas é impossível educar-se, se não se é educado por outros homens. A educação é, ao mesmo tempo, uma dinâmica interna (de um ser inacabado), e uma ação exercida do exterior (porque a humanidade é exterior ao homem). Essa relação interna/externa é que define a educação, com todas as consequências que isso traz do ponto de vista pedagógico. (CHARLOT, 2003, p. 32).

Nessa perspectiva, não cabe dúvida de que é na interação social que vamos nos construindo e o trabalho no ensino de PLAc oferece infinitas oportunidades de formação. A aproximação intercultural favorece o ativismo contra injustiças, o entendimento de que a diversidade é benéfica para a evolução humana nas várias áreas do conhecimento, e pode amenizar o risco da repetição de atrocidades históricas.

E nas palavras de Freire (1996, p. 86): 
[v]iver a abertura respeitosa aos outros e, de quando em vez, de acordo com o momento, tomar a própria prática de abertura ao outro como objetivo da reflexão crítica deveria fazer parte da aventura docente. A razão ética da abertura, seu fundamento político, sua referência pedagógica; a boniteza que há nela como viabilidade do diálogo. A experiência da abertura como experiência fundante do ser inacabado que terminou por se saber inacabado. Seria impossível saber-se inacabado e não se abrir ao mundo e aos outros à procura de explicação, de respostas a múltiplas perguntas. O fechamento ao mundo e aos outros se torna transgressão ao impulso natural da incompletude.

O sujeito que se abre ao mundo e aos outros inaugura com seu gesto a relação dialógica em que se confirma como inquietação e curiosidade, como inconclusão em permanente movimento na História.

É assim que nos sentimos e nos posicionamos, isto é, como seres em busca de aperfeiçoamento de saberes que nos favoreça fazer pequenas transformações no mundo, de modo a não concordar silenciosamente com injustiças, com falta de oportunidades que afetem a todos e todas. E acreditamos que por meio da educação, da oportunidade de ensinar e aprender isso pode se tornar realidade.

\section{Socialização dos conhecimentos construídos coletivamente}

No projeto de extensão houve curso de formação nos semestres anteriores, mas ainda não tinha sido realizado um momento de socialização nem entre os membros participantes, de modo oficial, nem com a comunidade acadêmica do IFG. Assim, essa lacuna foi preenchida com o I Seminário Movimentos Migratórios em V: português para falantes de outras línguas, cujo tema foi "Contextos virtuais de formação em movimento - a voz de estudiosos e as experiências de licenciandos regentes como professores de português para falantes de outras línguas", realizado de 19 a 26/09/2020.

Na cerimônia de abertura estavam muitas autoridades da comunidade acadêmica do IFG, do grupo inter-religioso que apoia os migrantes, os professores voluntários (regentes e orientadores), alunos haitianos, venezuelanos e de outras nacionalidades, que estão no programa de intercâmbio do IFG (PRÉ PEC-G), e convidados externos.

A compreensão sobre o que é acolhimento no ensino de idiomas parece ter ficado claro, o modo como se desenvolve o projeto, mesmo sem recursos financeiros adequados, ficou em evidência nos discursos dos convidados que fizeram a abertura oficial. Quem ainda não conhecia o trabalho da equipe aparentou encantamento diante das atividades apresentadas e quem já faz parte do projeto por ter trabalhado em outros anos explicitou sentimentos de gratidão pela oportunidade de realizar um movimento tão significativo socialmente.

O evento focou na troca de experiências incríveis que resultaria em ideias e aulas mais bem preparadas e planejadas, ao longo do semestre, tanto para serem execu- 
tadas no projeto, quanto para trabalharmos em escolas regulares, com alunos brasileiros. Reconhecemos que esse tenha sido o ápice do seminário, as trocas de experiências, cultura e aprendizagem.

O ponto culminante do evento para nós foram as apresentações de professores regentes e alunos (venezuelanos e haitianos). Essa parte foi muito legal porque a partir dali podíamos apresentar o que de fato preparávamos e aplicávamos em sala de aula virtual.

É com certeza um desafio enorme ser professora de português para estrangeiros, posto que estamos diante de pessoas com culturas e hábitos diferentes, principalmente diante de pessoas com idades e experiências diversas, o que torna tudo ainda mais desafiador, mas sem dúvidas o propósito continua sendo o mesmo, ensinar, aprender e acolher.

Os alunos que fazem parte do projeto precisam se aperfeiçoar na língua portuguesa, seja para se inserir social ou profissionalmente, seja para se aprovar em processos seletivos ou de qualificação como os vestibulares, Enem, Celpe-Bras, assim de um modo ou de outro eles têm sonhos e metas aqui no Brasil e fazer parte desses projetos é algo que nos demanda muita responsabilidade, ter esses momentos de partilhar é maravilhoso, pois é quando podemos intercambiar conhecimentos.

Durante todo o seminário, participamos de palestras, mesas-redondas, debates, oficinas e relatos de experiências, voltados para o ensino de português para estrangeiros. Nas palestras, chamou-nos muito a atenção o modo como as professoras que tinham formação específica na área falavam-nos das suas experiências práticas e teóricas e como tudo não era estranho ou desconhecido para nós, pois já executávamos e vivenciávamos muito do que foi mencionado, isso com certeza nos dava ainda mais ânimo para seguir acompanhando e planejando.

Em especial, a palestra que mais nos chamou a atenção foi a da professora Dra. Mirelle Amaral de São Bernardo, com o título "Aprendendo a acolher: ensino de língua para pessoas em vulnerabilidade", que teve como foco o ensino de português para pessoas em situação de vulnerabilidade. Nessa palestra, falou-se como o acolhimento e o envolver a cultura nas aulas são essenciais e deixam os alunos ainda mais envolvidos e animados em participar, pois sabemos das grandes dificuldades de todos em se manterem presentes e atentos.

O engajamento dos alunos na aula, na verdade, é um dos grandes desafios que enfrentamos diariamente, e nosso propósito é o planejamento de aulas envolventes que façam sentido para eles. A perspectiva da aula é justamente orientá-los não só com regras linguísticas, mas com um conteúdo que extrapole a prova que eles precisam fazer. A intenção é apresentar para eles formas diversas de comunicação (oral e escrita) para que desenvolvam habilidades para se comunicarem, tornando-se, portanto, competentes na exploração dos múltiplos sentidos em diferentes contextos e que tudo isso seja mostrado na prática interligando língua, literatura e cultura. 
Almeida Filho e Lombello (1997) ressaltam a grande importância da escolha de textos, diálogos e exercícios que sejam relevantes para a prática da língua que o aluno reconhece como a experiência válida de formação e crescimento intelectual. O que se ensina precisa ser significativo para o aluno, não se pode reduzir o trabalho docente a um mero cumprir de ementa ou de programa curricular. A preocupação constante no planejamento da aula circundava o questionamento sobre como, quando e onde o aluno poderia usar aquele conhecimento que seria socializado na sala de aula. Se não soubéssemos responder à pergunta, então aquilo indicava que o conteúdo não era pertinente.

Nossas aulas foram sempre trocas de experiências e o mais legal é que não só compartilhávamos o pouco que sabemos, mas aprendíamos muito com eles em todas as aulas. E não foi diferente no seminário, tivemos momentos ricos nos quais alunos haitianos e venezuelanos apresentaram para nós um pouco sobre a cultura e língua do seu país. Esse lugar de fala destinado a eles objetivava a sua valorização identitária. Eles se veem num momento histórico que precisam aprender o idioma do país onde estão, mas isso não precisa significar o apagamento de suas identidades, ao contrário, lutamos para que se mantenham vivas a língua e cultura de origem, e que o aprendizado de uma nova língua seja para suprir suas necessidades, estabelecer diálogo e comunicação, desenvolver projetos pessoais e ampliar de modo geral os conhecimentos que vão sendo construídos no país onde estão residindo, por motivo de força maior.

Por fim, tivemos nossas trocas de experiências, momentos de falar e citar um exemplo de aula exitosa em que a didática tenha sido funcional e que tenha ampliado uma perspectiva de ensino dinâmica. Escolhemos apresentar um plano de aula em que tivemos maior resposta dos alunos no que tange à comunicação e ao diálogo entre nós e eles. Falamos sobre o mundo do trabalho, sobre entrevistas e a distância entre os alunos no ensino remoto não representou um entrave na realização da proposta de atividade de interação comunicativa.

Eles gostaram muito desta e de outras atividades propostas para o desenvolvimento da comunicação oral, pois utilizamos dinâmicas que os faziam interagir um com o outro. Nessas experiências, escutamos muitos planos muito bem elaborados e executados. E percebemos o quanto o acolhimento nos demais grupos do projeto eram semelhantes ao nosso. Em síntese, podemos concluir que o projeto é um espaço de ricas experiências tanto para a formação docente, quanto para o aluno, mas, especialmente, para o ser humano se humanizar.

\section{Referências}

ALMEIDA, B. O.; ALVES, L. R. G. Letramento digital em tempos de Covid-19: uma análise da educação no contexto atual. Debates em Educação, Maceió, v. 12, n. 28, 
p. 1-18, set-dez. 2020. Disponível em: https://www.seer.ufal.br/index.php/debateseducacao/article/view/10282. Acesso em: 11 dez. 2020.

ALMEIDA FILHO, J. C. P., LOMBELLO L. C. (orgs.). O ensino de Português para estrangeiros: Pressupostos para o planejamento de cursos e elaboração de materiais. 2. ed. Campinas, SP: Pontes, 1997.

CHARLOT, B. O sujeito e a relação com o saber. Trad. Vicente Emídio Alves. In: BARBOSA, Raquel Lazzari Leite (org.). Formação de educadores: Desafios e perspectivas. São Paulo: UNESP, 2003. p. 23-34.

FIGUEIREDO, F. J. Q. de. A aprendizagem colaborativa de línguas: considerações conceituais e aplicações em distintos contextos. In: FIGUEIREDO, F. J. Q. de. A aprendizagem colaborativa de línguas. Goiânia: Editora UFG, 2018. p. 13-57.

FIGUEIREDO, F. J. Q. de. Aprendendo com os erros. Goiânia: Editora UFG, 2002. p. 24-41.

FREIRE, P. Pedagogia da Autonomia. Digitalizada pelo Coletivo Sabotagem (2002), 1996. Disponível em: http://plataforma.redesan.ufrgs.br/biblioteca/pdf_bib.php? COD_ARQUIVO=17338. Acesso em: 3 dez. 2020.

IMBERNÓN, F. Formação continuada de professores. Porto Alegre: Artmed, 2010.

MOITA, M. da C. Percursos de formação e de trans-formação. In: NÓVOA, A. (org.). Vidas de Professores. Porto, Portugal: Porto, 2000. p. 111-140.

NÓVOA, A. Os professores e as histórias da sua vida. In: NÓVOA, A. (org.). Vidas de professores. Porto, Portugal: Porto, 2000. p. 11-30.

RAJAGOPALAN, K. Por uma Linguística crítica. Linguagem, identidade e a questão ética. São Paulo: Parábola Editorial, 2003.

SANTOS, B. de S. A Cruel Pedagogia do Vírus. Coimbra: Almedina, 2020.

SÃO BERNARDO, M. A. de. Português como língua de acolhimento: um estudo com imigrantes e pessoas em situação de refúgio no Brasil. 2016. 206 f. Tese (Doutorado em Linguística) - Universidade Federal de São Carlos. São Carlos, 2016. Disponível em: https://repositorio.ufscar.br/handle/ufscar/8126?show =full. Acesso em: 19 set. 2020. 


\section{ORGANIZADORAS/AUTORAS}
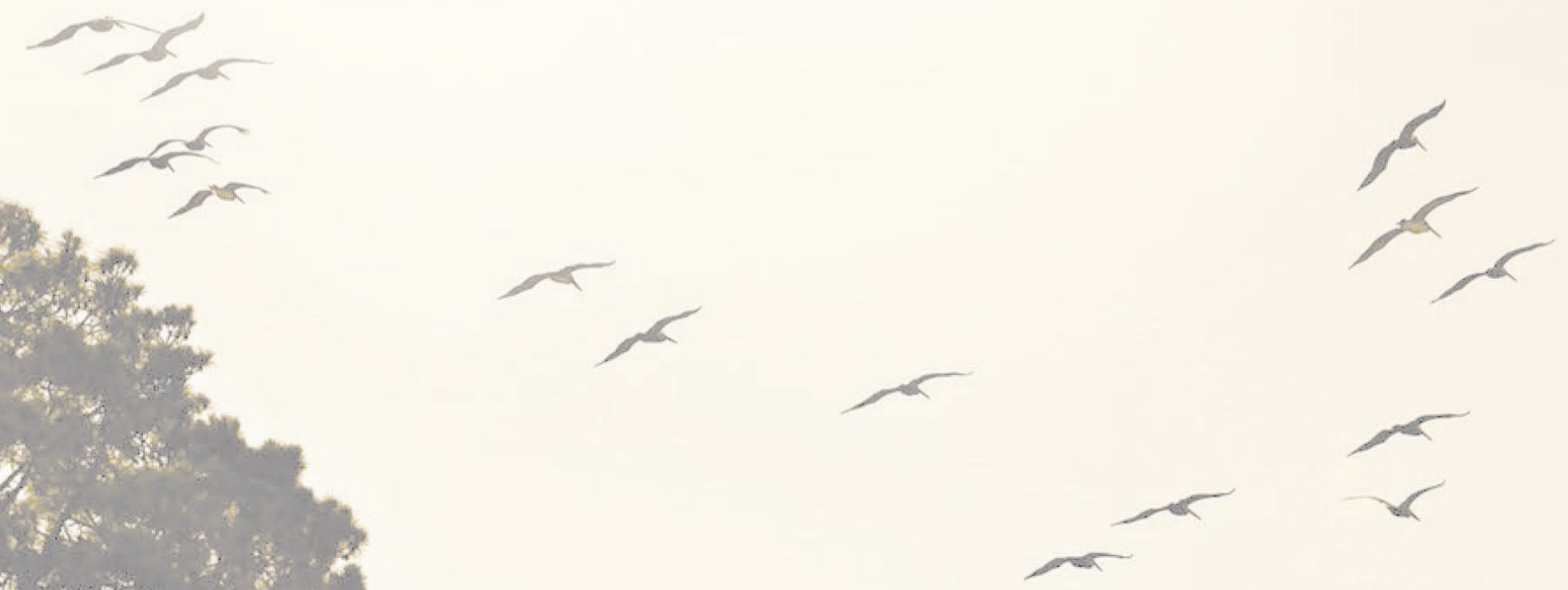

7

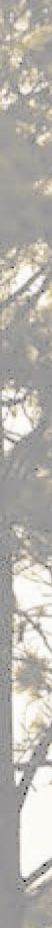




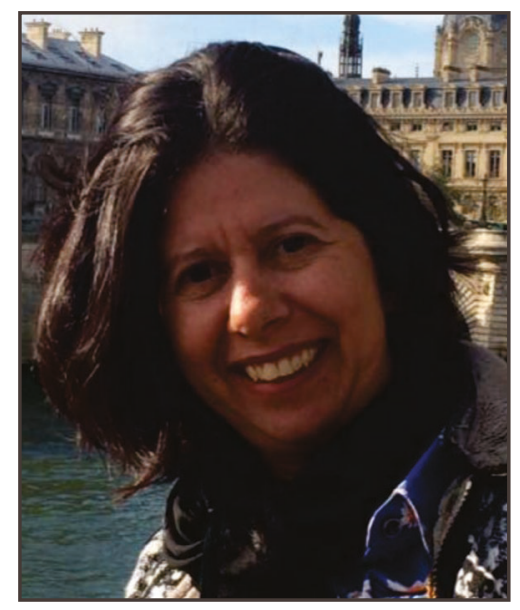

\section{Suelene Vaz da Silva}

Professora efetiva, IFG, câmpus Goiânia, vinculada à Coordenação de Linguagens, Códigos e suas Tecnologias, desde 2007. Coordenadora Geral e orientadora didática no Projeto de Extensão para o ensino de português para imigrantes desde agosto/2017/2. Bacharel e Licenciada em Letras: Português/Inglês (1988), pela Universidade Federal de Goiás. Mestre (2006) e Doutora (2012) em Letras e Linguística, também pela Universidade Federal de Goiás. Membro do Núcleo de Pesquisa e Extensão em Tecnologias de Processos Sustentáveis (NUPTECS), cadastrado no IFG e no CNPq.

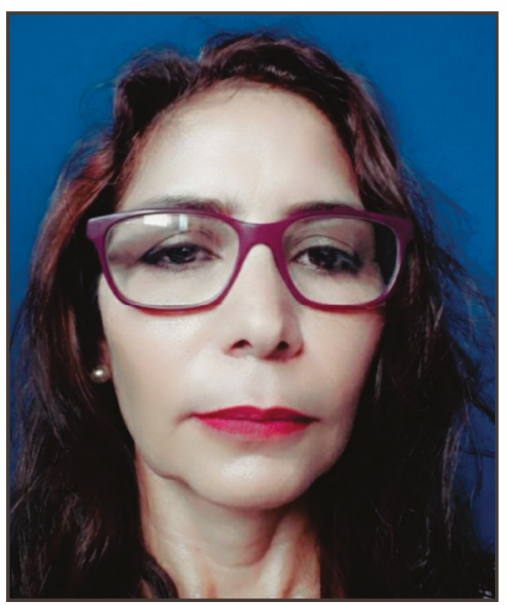

\section{Cleide Araújo Machado}

Professora efetiva, IFG, câmpus Goiânia, vinculada à Coordenação de Linguagens, Códigos e suas Tecnologias, desde 2008. Coordenadora Auxiliar e orientadora didática no Projeto de Extensão para o ensino de português para imigrantes desde agosto de 2018. Graduada em Letras: Português/Espanhol (2003), pela Universidade Federal de Goiás e Mestre em Letras e Linguística (2006), também pela Universidade Federal de Goiás.

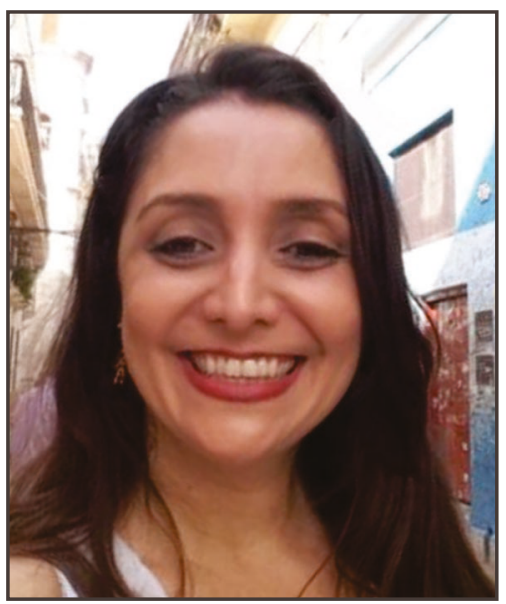

\section{Mirelle Amaral de São Bernardo}

Professora efetiva, IF Goiano, câmpus Ceres, desde 2012. Participante do Projeto de Extensão para o ensino de português para imigrantes edição 2017/22018/1. Graduada em Letras: Português/Inglês (2003), pela Universidade Estadual de Goiás. Mestre em Linguística Aplicada (2011), pela Universidade Federal de São Carlos, e Doutora em Linguística (2016), pela Universidade Federal de São Carlos. 


\section{PROFESSORES ORIENTADORES NO PROJETO MoVe}

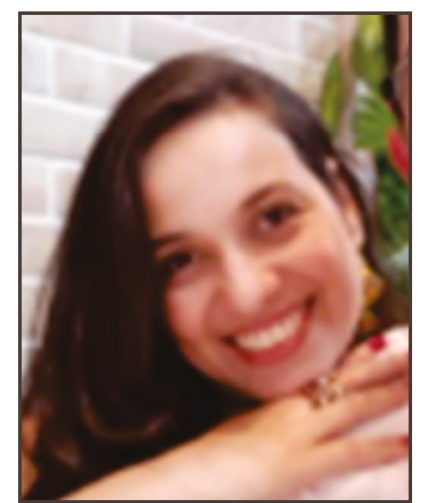

\section{Alita Carvalho Miranda Paraguassú}

Professora efetiva, IFG, câmpus Goiânia, vinculada à Coordenação de Linguagens, Códigos e suas Tecnologias, desde 2013. Orientadora didática no Projeto de Extensão para o ensino de português para imigrantes em 2020. Graduada em Letras (2010), pela Universidade Federal de Goiás. Mestre (2013) e Doutora (2017) em Letras e Linguística, também pela Universidade Federal de Goiás. Líder do Núcleo de Estudos Discursivos e Enunciativos, cadastrado no CNPq.

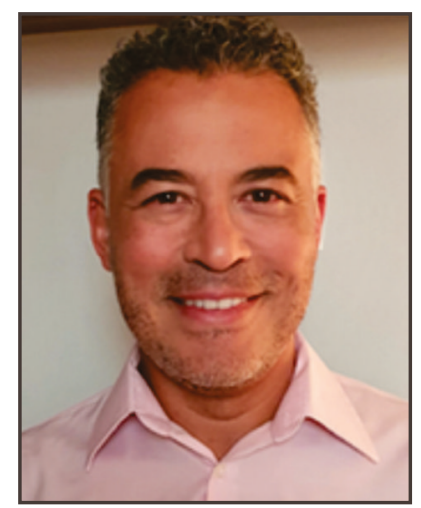

\section{Liberato Santos da Silva}

Professor efetivo, IFG, câmpus Goiânia, vinculado à Coordenação de Linguagens, Códigos e suas Tecnologias, desde 2009. Orientador didático no Projeto de Extensão para o ensino de português para imigrantes em 2020. Graduado em Letras: Português/Inglês (2008), pela Pontifícia Universidade Católica de Goiás, e Mestre em Linguística Aplicada (2010), pela Universidade de Brasília. Doutorando em Linguística Aplicada e Tecnologia, pela lowa State University, IASTATE, Estados Unidos.

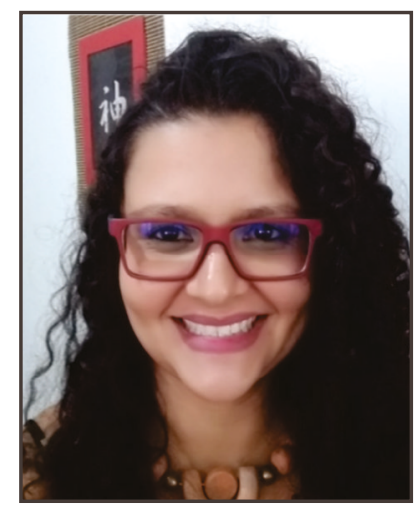

\section{Paula Graciano Pereira}

Professora efetiva, IFG, câmpus Goiânia, vinculada à Coordenação de Linguagens, Códigos e suas Tecnologias, desde 2010. Orientadora didática no Projeto de Extensão para o ensino de português para imigrantes em 2020. Graduada em Letras (2004), pela Universidade Federal de Goiás. Mestre (2007) e Doutora (2013) em Letras e Linguística, também pela Universidade Federal de Goiás. Membro do Núcleo de Pesquisas da Cultura, Linguagem e suas Tecnologias (Necult-IFG), cadastrado no CNPq. 


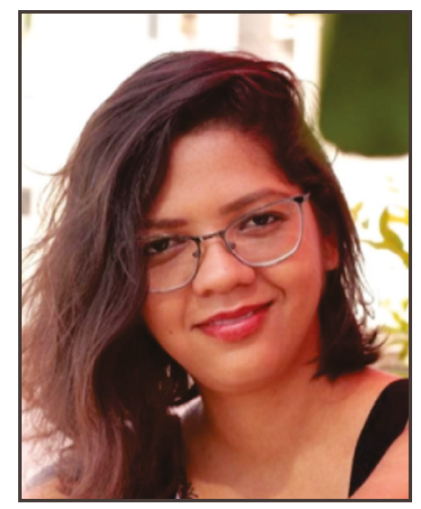

\section{Thaise Monteiro da Silva Melo}

Professora Temporária no IFG, câmpus Goiânia, vinculada à Coordenação de Linguagens, Códigos e suas Tecnologias, desde 2020/1. Orientadora didática no Projeto de Extensão para o ensino de português para imigrantes desde junho/2020. Bacharel em Letras, com habilitação em Estudos Literários (2011) e Licenciada em Letras, com habilitação em Língua Portuguesa (2011), pela Universidade Federal de Goiás. Mestre (2014) e Doutora (2018) em Letras e Linguística, também pela Universidade Federal de Goiás. Escritora e fundadora da Cia de Arte Poesia que Gira, onde atua como atriz, assim como em outros grupos teatrais da capital goiana.

\section{PROFESSORES VOLUNTÁRIOS NO PROJETO MoVe}

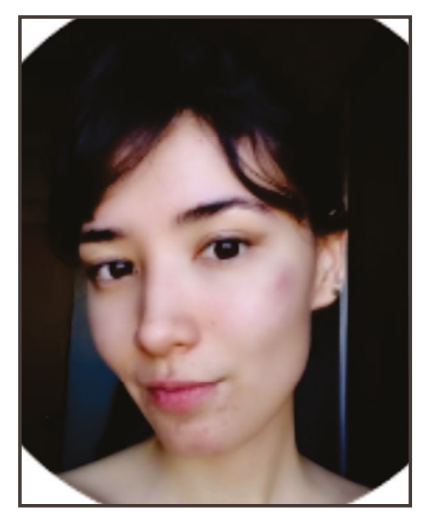

\section{Amanda de Sousa Ywamoto}

Aluna do curso de Licenciatura em Letras: Língua Portuguesa, IFG, câmpus Goiânia, cursando o $7^{\circ}$ período. Professora voluntária no Projeto de Extensão MoVe, edições presenciais, desde agosto de 2019/2 e no MoV(irtual) em 2020.

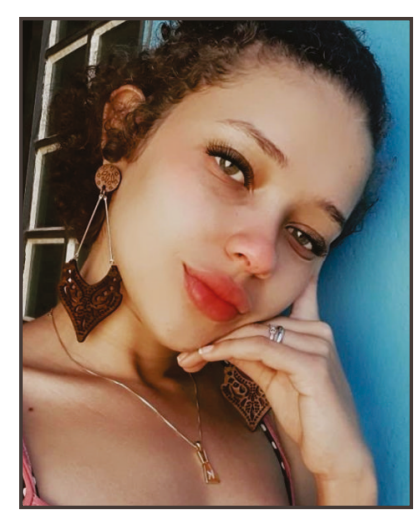

\section{Ana Cristina de Moura dos Santos}

Aluna do curso de Licenciatura em Letras: Língua Portuguesa, IFG, câmpus Goiânia, cursando o $6^{\circ}$ período. Professora voluntária no Projeto de Extensão MoVe, edições presenciais, desde abril de 2019/1 e no MoV(irtual) desde 2020. 


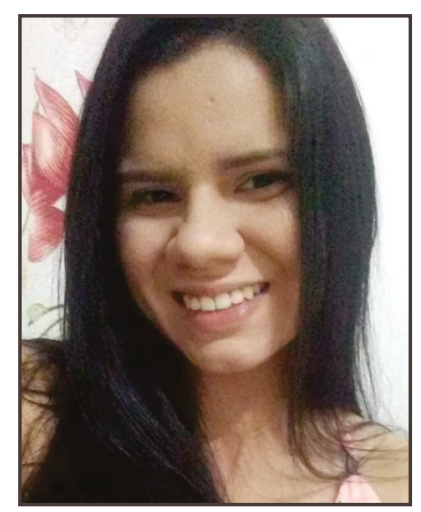

\section{Angélica Maria Lourenço Moreira}

Aluna do curso de Especialização em Docência em Educação e Tecnologia do IFG, câmpus Goiânia Oeste. Egressa do curso de Letras: Língua Portuguesa. Professora voluntária no Projeto de Extensão MoV(irtual), em 2020.

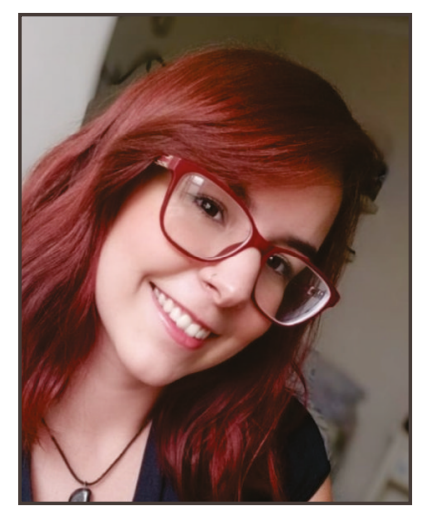

\section{Clara Oliveira Campos}

Aluna do curso de Licenciatura em Letras: Língua Portuguesa, IFG, câmpus Goiânia, cursando o $6^{\circ}$ período. Professora voluntária no Projeto de Extensão MoVe, edições presenciais, desde abril de 2019/1 e no MoV(irtual) desde 2020.

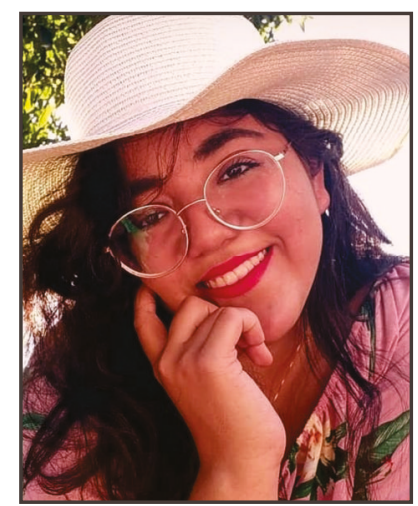

\section{Fabiana Thais Pereira Pedraza}

Aluna do curso de Especialização em Políticas e Gestão da Educação Profissional e Tecnológica do IFG, câmpus Goiânia e do curso de Especialização em Docência em Educação e Tecnologia do IFG, câmpus Goiânia Oeste. Egressa do curso de Letras: Língua Portuguesa. Professora voluntária no Projeto de Extensão MoV(irtual) desde 2020. 


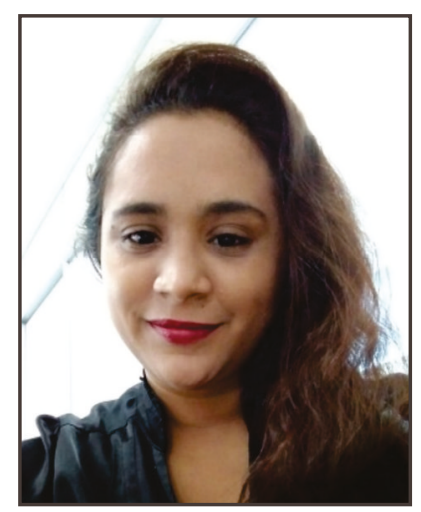

\section{Hamayana Silva Melo}

Aluna egressa do curso de Licenciatura em Letras: Língua Portuguesa, IFG, câmpus Goiânia. Professora voluntária no Projeto de Extensão MoVe, edições presenciais, desde setembro de 2018/2 e no MoV(irtual) em 2020.

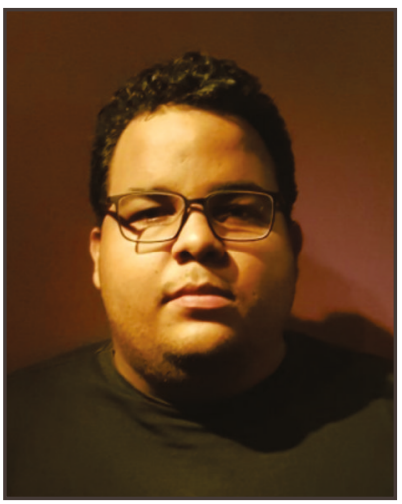

\section{Isaque Lima da Silva}

Aluno do curso de Licenciatura em Letras: Língua Portuguesa, IFG, câmpus Goiânia, cursando o $7^{\circ}$ período. Professor voluntário no Projeto de Extensão MoV(irtual) desde 2020.

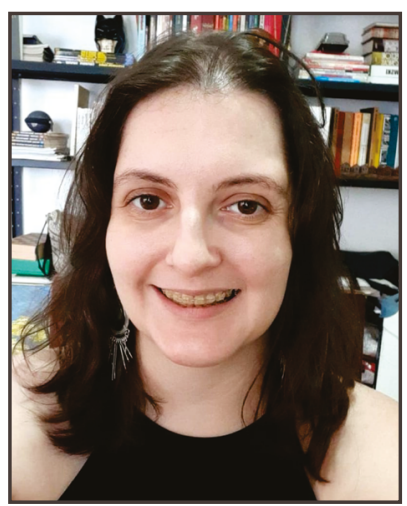

\section{Kamilla Christina Alves}

Aluna do curso de Especialização em Docência em Educação e Tecnologia, IFG, câmpus Luziânia e do curso de Especialização em Linguística Aplicada: ensino-aprendizagem de português para estrangeiros, Mentes Abertas, Paraíba. Professora voluntária no Projeto de Extensão MoVe, edições presenciais, desde abril de 2019/1 e no MoV(irtual) desde 2020. 


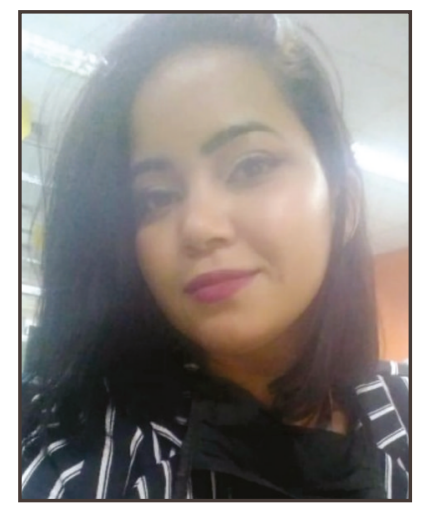

\section{Katiele Ribeiro Oliveira}

Aluna do curso de Licenciatura em Letras: Língua Portuguesa, IFG, câmpus Goiânia, cursando o $7^{\circ}$ período. Professora voluntária no Projeto de Extensão MoVe, edições presenciais, desde agosto de 2019/2 e no MoV(irtual) em 2020.

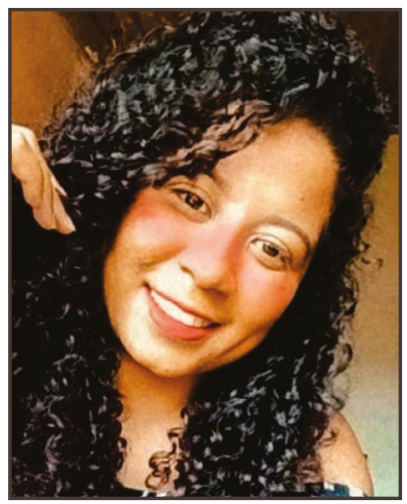

\section{Lívia Regina Borges Pereira}

Aluna egressa do curso de Licenciatura em Letras: Língua Portuguesa, IFG, câmpus Goiânia. Professora voluntária no Projeto de Extensão MoVe, edições presenciais, desde agosto de 2019/2 e no MoV(irtual) em 2020.

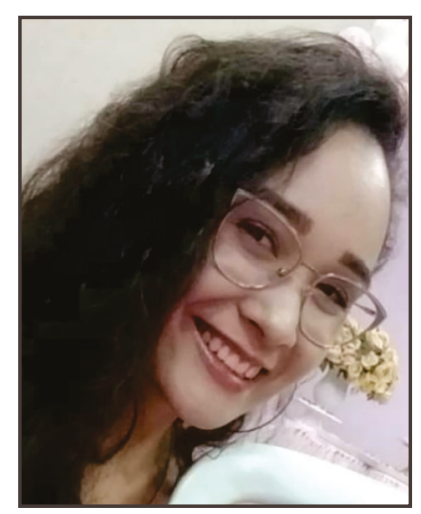

\section{Mariana Alves de Oliveira}

Aluna do curso de Especialização em Políticas e Gestão da Educação Profissional e Tecnológica do IFG, câmpus Goiânia. Aluna egressa do curso de Licenciatura em Letras: Língua Portuguesa, IFG, câmpus Goiânia. Professora voluntária no Projeto de Extensão MoV(irtual) em 2020. 


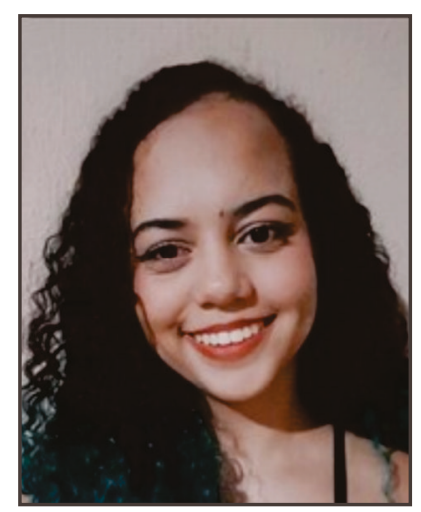

\section{Milena de Oliveira Gomes}

Aluna do curso de Licenciatura em Letras: Língua Portuguesa, IFG, câmpus Goiânia, cursando o $7^{\circ}$ período. Professora voluntária no Projeto de Extensão MoV(irtual) em 2020.

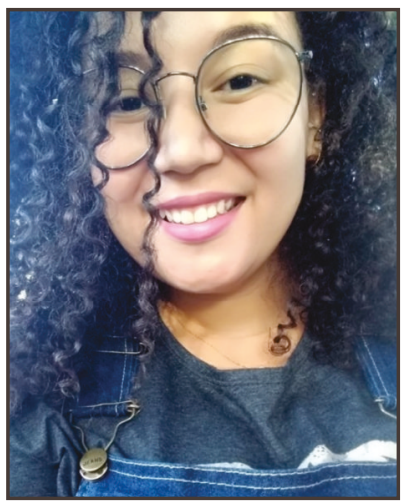

\section{Nayara Costa Araújo}

Aluna egressa do curso de Licenciatura em Letras: Língua Portuguesa, IFG, câmpus Goiânia. Professora voluntária no Projeto de Extensão MoVe, edições presenciais, desde abril de 2019/1 e no MoV(irtual) desde 2020.

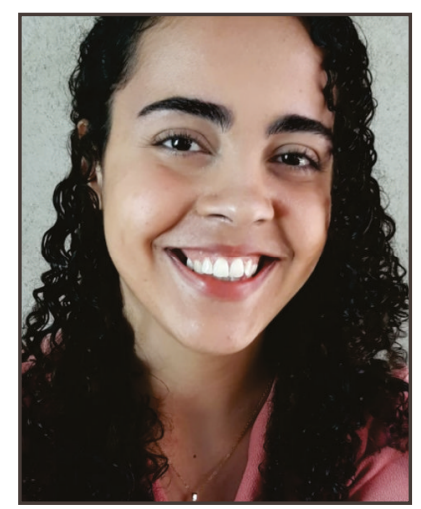

\section{Thalía Marques de Andrade}

Aluna egressa do curso de Licenciatura em Letras: Língua Portuguesa, IFG, câmpus Goiânia. Professora voluntária no Projeto de Extensão MoV(irtual), desde 2020. 